\title{
15. OLIGOCENE THROUGH QUATERNARY PLANKTONIC FORAMINIFERAL BIOSTRATIGRAPHY OF THE NORTH ATLANTIC: DSDP LEG 49
}

\author{
R.Z. Poore, U.S. Geological Survey, Menlo Park, California
}

\begin{abstract}
Nine holes were drilled at eight sites in three areas of the North Atlantic during DSDP Leg 49. Sites 407 through 409 constitute a west-east transect on the west flank of the Reykjanes Ridge. Unconformities are present between the lower and middle Miocene, middle and upper Miocene, and Pliocene and Quaternary in the Oligocene through Quaternary section of Hole 407. A Pliocene/Quaternary unconformity and a probable middle/ upper Miocene unconformity occur in the lower Miocene through Quaternary section of Hole 408. Although data from the questionable upper Pliocene through Quaternary section of Hole 409 are too sparse to allow recognition of an unconformity, the presence of a Pliocene/Quaternary unconformity at Sites 407 and 408 indicates that the unconformity is a regional feature related to increased bottom current or to turbidity current activity associated with one or more major late Cenozoic climatic events. Miocene unconformities were caused by changes in bottom current activity probably related to the subsidence history of the Iceland-Faeroe Ridge.

Upper Miocene to Quaternary sediments were recovered from Hole 410, which is situated at lat $45^{\circ} \mathrm{N}$ on the west side of the Mid-Atlantic Ridge. The occurrence of ice-rafted mineral grains in the Pliocene of Hole 410, at a level estimated to be about $3 \mathrm{~m}$.y. old, confirms and extends the coverage of the mid-Pliocene North Atlantic glacial event detected during DSDP Leg 12.

The remaining holes drilled during Leg 49 recovered Quaternary sediments in the FAMOUS area.

Four lower Miocene, three middle Miocene, one upper Miocene, two Pliocene, and one Quaternary biostratigraphic divisions are proposed for high-latitude Neogene sediments of the North Atlantic. These informal zones are correlated with formal zonation schemes developed in tropical and extra-tropical areas.
\end{abstract}

\section{INTRODUCTION}

DSDP Leg 49 started in Aberdeen, Scotland, on 18 July 1976, and ended at the island of Madeira on 4 September 1976. Nine holes were drilled at eight sites in three areas of the North Atlantic Ocean (Figure 1; Table 1).

Sites 407 to 409 constitute a west-east transect on the west flank of the Reykjanes Ridge. Planktonic foraminifers are present throughout the composite Oligocene to Quaternary sedimentary section recovered at these sites, but foraminifers are generally sparse and poorly preserved in the older portion of the section. The Neogene sediments recovered at these sites contain both siliceous and calcareous microfossils from this sparsely sampled area of the North Atlantic Basin, and will undoubtedly prove extremely valuable to future paleobiogeographic and paleoceanographic studies.

Site 410 is at lat $45^{\circ} \mathrm{N}$ on the west side of the Mid-Atlantic Ridge. An upper Miocene to Quaternary sedimentary section containing abundant and well-preserved planktonic foraminifers was recovered from Hole 410.

The remaining sites where coring was accomplished during Leg 49 are in the FAMOUS area. Because the primary objective in this area was to sample young ocean crust, only Quaternary sediments were recovered.
For the purposes of this preliminary study, core-catcher samples were usually examined in Quaternary sections, whereas in general, core-catcher samples and an additional sample per sediment core were examined in the preQuaternary.

Abundance estimates of planktonic foraminifer taxa and other selected constituents of samples examined for this report are provided in Tables 2 through 7 . After dispersing a more or less uniform amount of processed material $(\geqslant 149$ $\mu \mathrm{m}$ size fraction) on a standard 60-square micropaleontologic slide, abundances were estimated as follows. Sample constituents occurring several times per square were tabulated as abundant, those occurring about once per square were tabulated as common, and those occurring once per several squares were tabulated as few. Sample constituents requiring a more extensive search or encountered only in the $\geqslant 149 \mu \mathrm{m}$ size fraction were tabulated as sparse. These qualitative data are intended primarily to aid interested researchers in selection of appropriate samples for future study. Abbreviated sample designations follow standard DSDP convention.

To facilitate age determinations and comparisons of the results of Leg 49 with other studies, I have interpreted the planktonic foraminiferal assemblages encountered in terms 


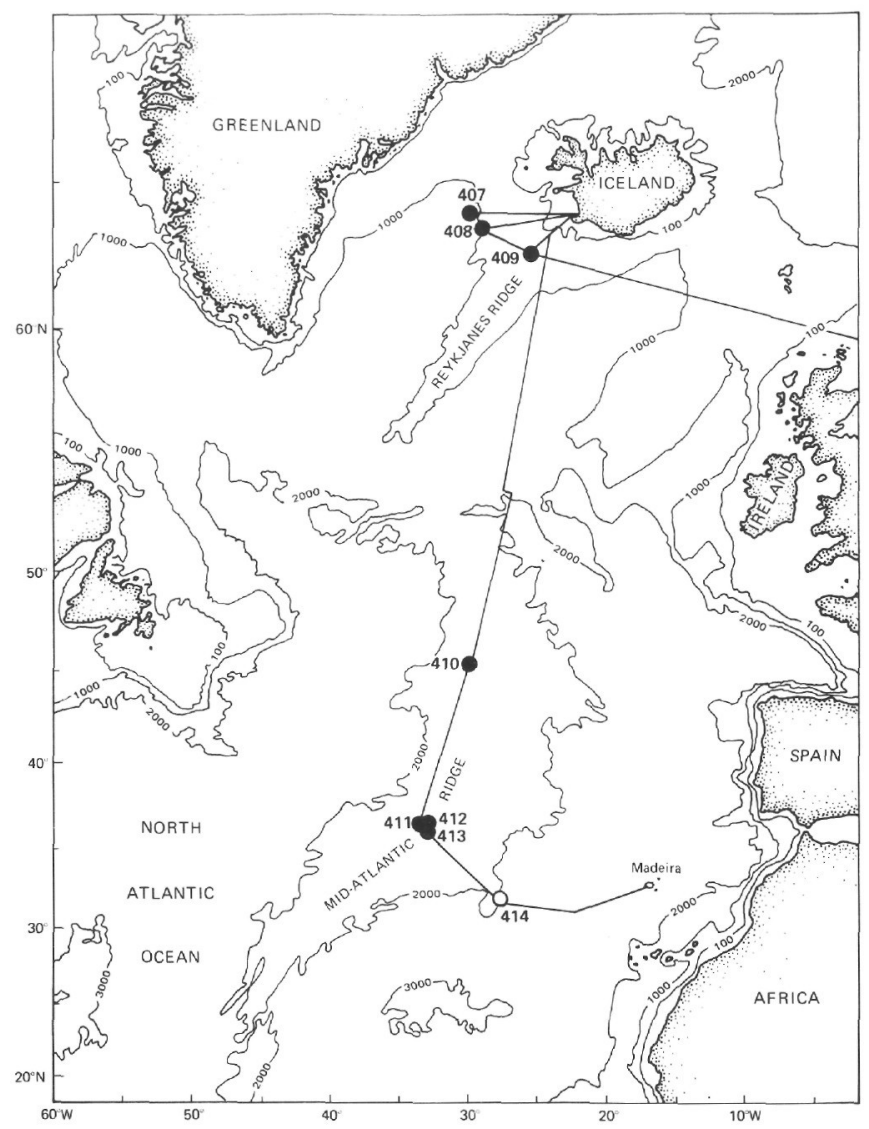

Figure 1. Sketch map showing location of Leg 49 sites, taken from Luyendyk, Cann, et al. (1977). (Depth contours are in fathoms.)

of the standard zonation of Blow (1969). After presentation and discussion of data from all Leg 49 sites, an informal biostratigraphic zonation suitable for high-latitude, North Atlantic, Neogene planktonic foraminiferal assemblages is proposed and correlated with zonal schemes developed in tropical and extra-tropical areas of both hemispheres.

Original designations of taxa identified during this study, as well as comments on informally recognized and other selected taxa, are provided in the Taxonomic Notes.

\section{REYKJANES RIDGE TRAVERSE: SITES 407 THROUGH 409}

\section{Site 407}

Site 407 is on anomaly 13 on the west flank of the Reykjanes Ridge (Tabie 1; Figure 1), and forms the west end of the west-east transect drilled on the Reykjanes Ridge. Expected age for basement at this location is 36 to $38 \mathrm{~m}$.y. (Berggren and Van Couvering, 1974).

Hole 407 was continuously cored to 458.5 meters subbottom, and basalt was first encountered at approximately 304 meters. At least three thin (?) layers of sediment are present below basalt. The deepest $(43, \mathrm{CC} ; 405 \mathrm{~m}$ subbottom) is about 100 meters below the first basalt. Preservation and abundance of planktonic foraminifers in the Oligocene to Quaternary sediments recovered from Hole 407 are variable. Foraminifers in samples from sediments intercalated with basalt (Cores 43,36 , and 35) are few to common
TABLE 1

Locations and Water Depths (corrected $\mathrm{m}$ ) of Sites Where Sediment Was Recovered During Leg 49

\begin{tabular}{cccc}
\hline Site & $\begin{array}{c}\text { Latitude } \\
(\mathrm{N})\end{array}$ & $\begin{array}{c}\text { Longitude } \\
(\mathrm{W})\end{array}$ & $\begin{array}{c}\text { Water } \\
\text { Depth (m) }\end{array}$ \\
\hline 407 & $63^{\circ} 56.32^{\prime}$ & $30^{\circ} 34.56^{\prime}$ & 2472 \\
408 & $63^{\circ} 22.63^{\prime}$ & $28^{\circ} 54.71^{\prime}$ & 1624 \\
409 & $62^{\circ} 36.98^{\prime}$ & $25^{\circ} 57.17^{\prime}$ & 832 \\
410 & $45^{\circ} 30.51^{\prime}$ & $29^{\circ} 28.56^{\prime}$ & 2975 \\
411 & $36^{\circ} 45.97^{\prime}$ & $33^{\circ} 23.30^{\prime}$ & 1935 \\
412 & $36^{\circ} 33.74^{\prime}$ & $33^{\circ} 09.96^{\prime}$ & 2609 \\
413 & $36^{\circ} 32.59^{\prime}$ & $33^{\circ} 10.50^{\prime}$ & 2598 \\
\hline
\end{tabular}

and at best only moderately well preserved. Glauconite grains and fragments of glauconite fillings of foraminifers are abundant in these samples. Foraminifers are common in samples from just above the basalt (Cores 32 through 29), but preservation is generally poor, particularly in samples from Cores 32 and 31. Preservation of foraminifers is good in samples from Cores 28 through 19 , but foraminifers are few to sparse in most samples, although they become somewhat more abundant up-hole. Most individuals present are nondiagnostic juvenile forms. It is not clear whether the scarcity of foraminifers in this interval is a result solely of dilution by siliceous material or if it was caused in part by dissolution. The qualitative data presently available for these samples are not sufficient to resolve this question. With few exceptions, foraminifers are common to abundant and well preserved in the remaining up-hole samples examined from Hole 407. Occurrence of planktonic foraminifers and other selected constituents of samples from Hole 407 are shown on Table 2.

Sample 43, CC contains common, well-developed Globigerina angiporoides, Globorotalia munda, Chiloguembelina cubensis, Catapsydrax gortanii, and $C$. dissimilis dissimilis. This assemblage is assigned to Zonal interval P 19-P 20. It is possible that this assemblage could represent the lower part of Zone P 21, but the abundance of typical Globigerina angiporoides and the presence of Globorotalia munda favor an age assignment older than Zone $P$ 21. According to the time-scale of Berggren and Van Couvering (1974), the oldest sediments of Hole 407 are at least several million years younger than the expected age of basement.

Samples from Cores 35 and 36 are dominated by representatives of Globigerina praebulloides s.l. and G. ouachitaensis s.1. Globigerina praebulloides is extremely variable in these samples, and many members of the population approach the morphology of the younger Globigerina bulloides. Accessory taxa include Globorotalia opima or forms very close to G. opima, Catapsydrax dissimilis ciperoensis, and, in Sample 36-2, 52-54 cm, Globigerinita praestainforthi. My preferred interpretation is to assign these samples to Zone P 21.

The assemblage in Sample 32, CC, above the first basalt, is not particularly diagnostic but does contain Globorotalia opima, as does Sample 31, CC. Globorotalia kugleri occurs in Sample 31-4, 27-29 cm, and ranges up through Sample 29, CC, with a possible occurrence in Sample 28, CC. One specimen of Globigerinoides primordius was detected in Sample 30, CC. I place the base of the Miocene just below this single occurrence of Globigerinoides primordius be- 
TABLE 2

Occurrence of Planktonic Foraminifers and Other Selected Constituents in Samples from Hole 407
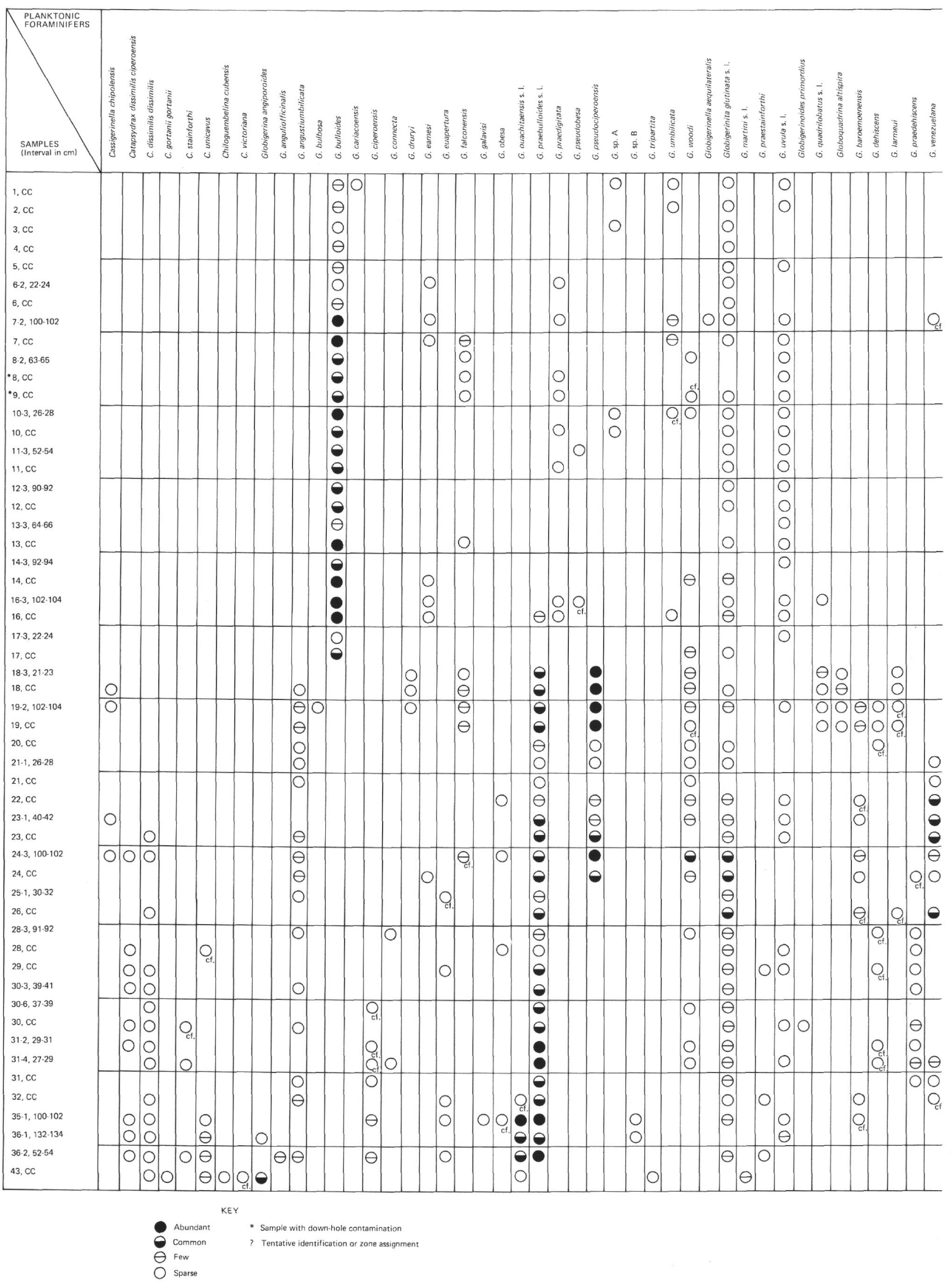


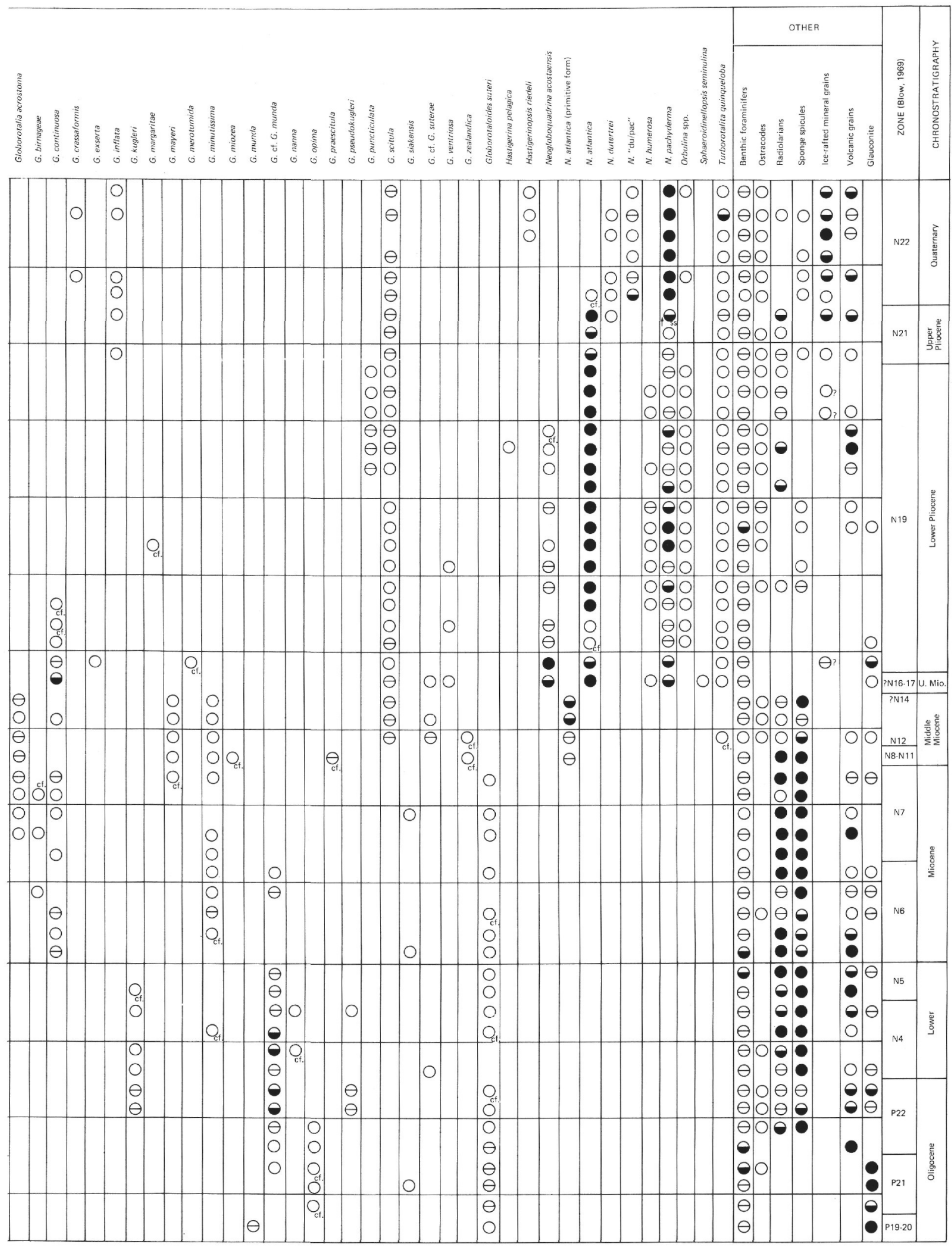


TABLE 3

Occurrence of Planktonic Foraminifers and Other Selected Constituents in Samples from Hole 408

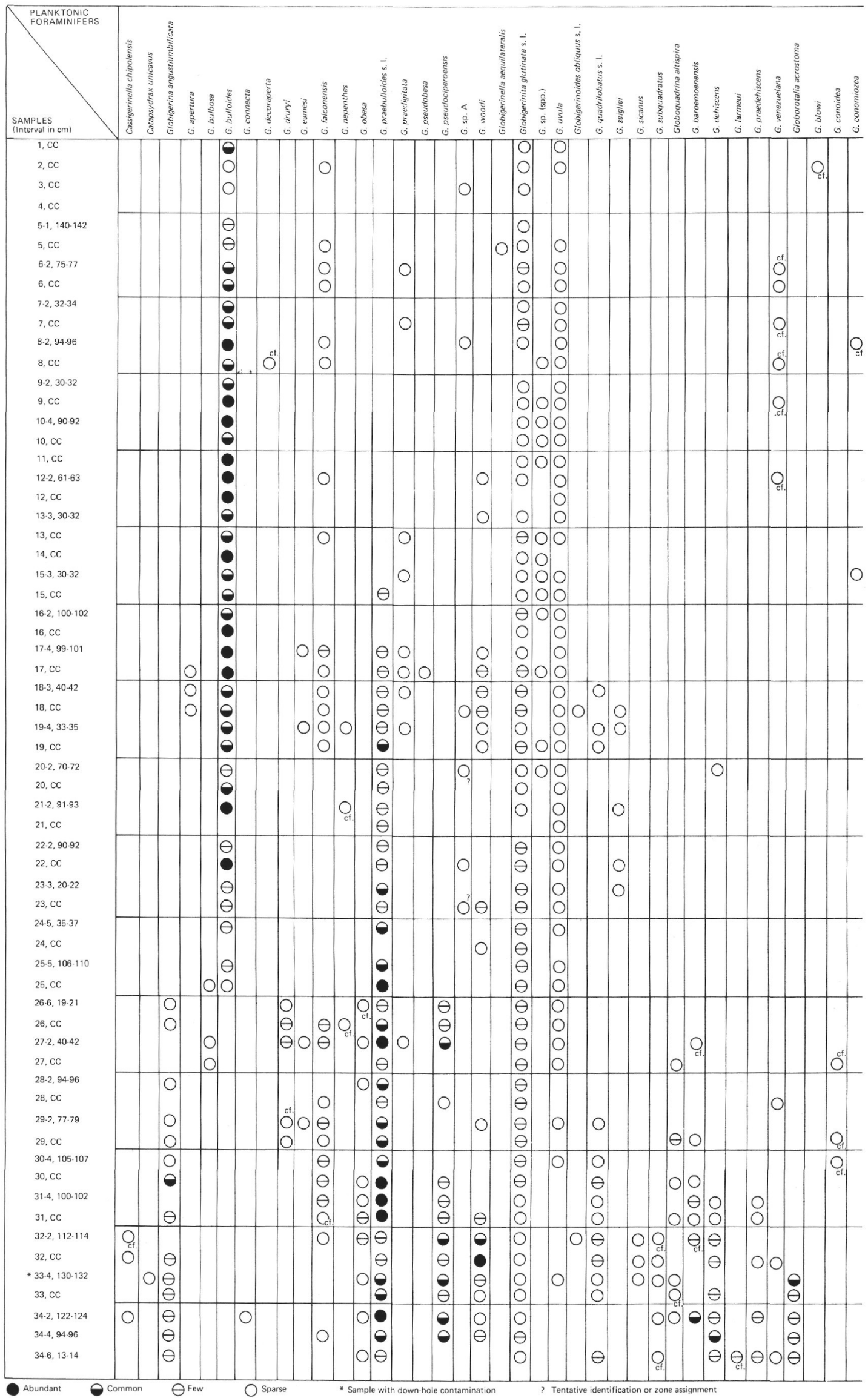


TABLE 3 - Continued

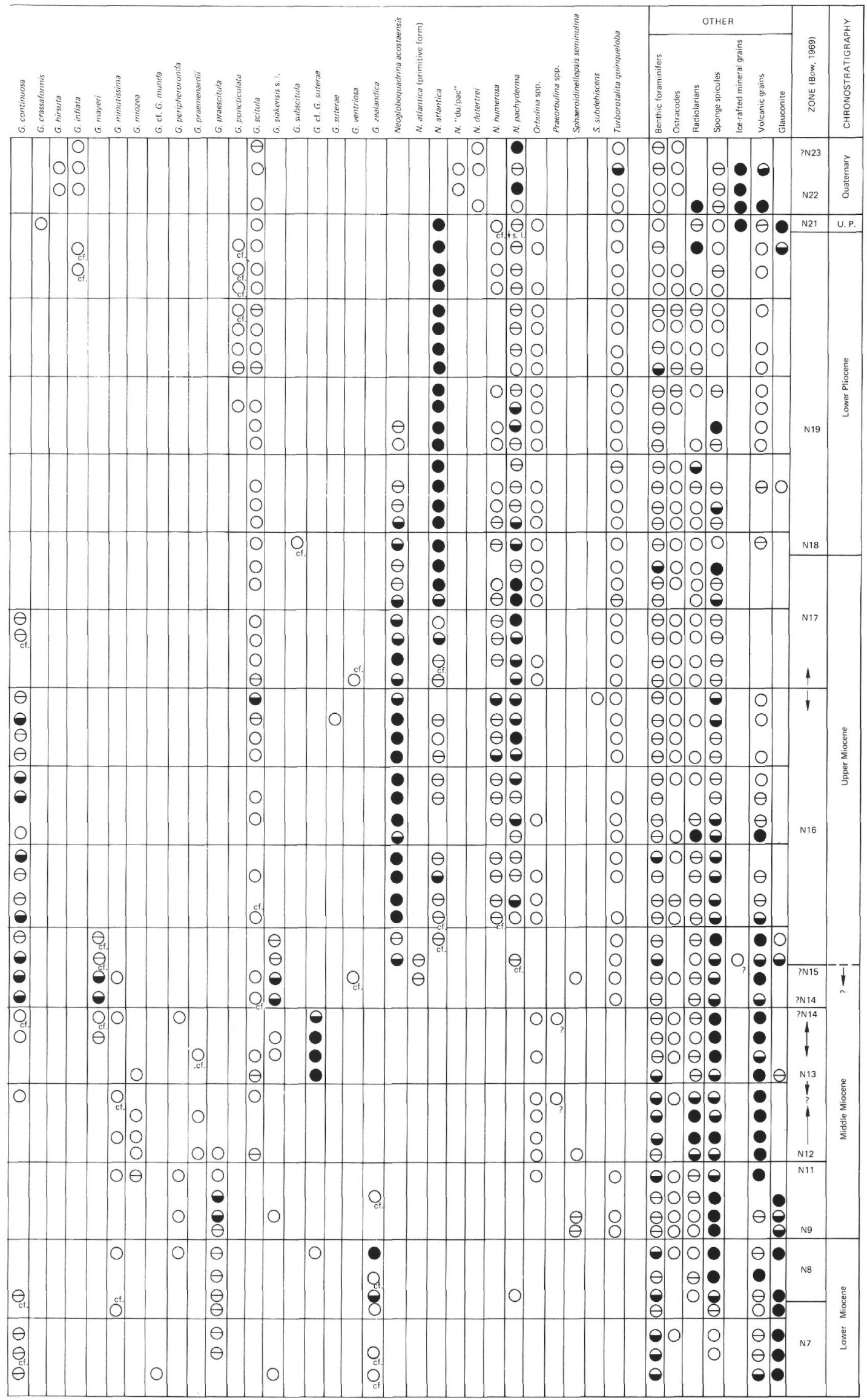


TABLE 4

Occurrence of Planktonic Foraminifers and Other Selected Constituents in Samples from Hole 409

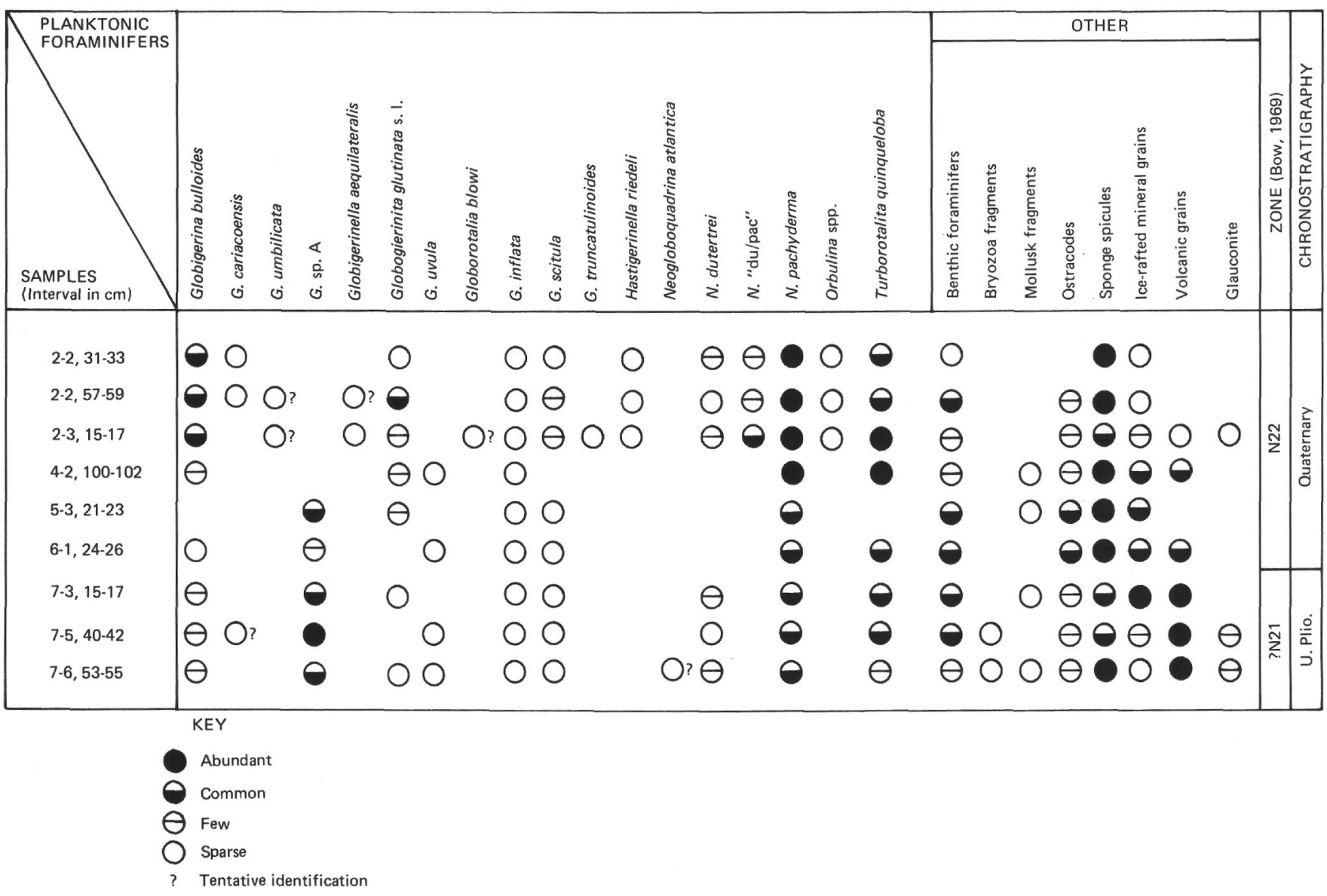

cause it is within the range of Globorotalia kugleri, which has a limited stratigraphic range spanning the Oligocene/ Miocene boundary (Blow, 1969; Stainforth et al., 1975), and above the first occurrence of Globoquadrina praedehiscens, which begins in Zone P 22 (Blow, 1969; Berggren and Amdurer, 1973). Samples $32, \mathrm{CC}$ to $31-2,29-31 \mathrm{~cm}$, are assigned to Zone P 22. The nannofossil assemblages from this interval are compatible with the interpretations given here (see Steinmetz, this volume).

The top of Zone N 4 is drawn above Sample 29, CC, on the basis of the last (highest) occurrence of reliably identified Globorotalia kugleri. Similarly, the last occurrence of Catapsydrax dissimilis s.l. is used to draw the upper limit of Zone N 6 above Sample 23, CC (Zones N 5 and N 6 cannot be separated in these samples). The lowest occurrence of Globorotalia minutissima in Sample 24, CC supports this interpretation, since this taxon first occurs in Zone N 6. But the occurrences of Globorotalia birnageae in Sample 24-3, 100-102 cm, G. continuosa in Sample 26, CC, and Globigerina pseudociperoensis in Sample 24, CC - all of whose lower limits are thought to be in Zone N 7 - suggest the possibility that Cores 23 through 26 should be assigned to Zone N 7.

Although foraminiferal assemblages in samples just above Sample 23, CC are not particularly age-diagnostic, the occurrence of Globorotaloides suteri through Sample 20, CC suggests a level no younger than Zone N 8. Moreover, gross comparison of foraminiferal assemblages from Cores 407-23 through 407-20 with assemblages from Hole 408 that can be correlated with upper part of Zone $\mathrm{N} 7$ and Zone $\mathrm{N} 8$ reveals significant differences. In Hole 408, samples referable to Zones $\mathrm{N} 7$ and N 8, Globigerinoides quadrilobatus s.1., G. subquadratus, G. sicanus (Zone N 8 only), Globorotalia praescitula, and typical G. zealandica, are consistent and sometimes common components of the assemblages. None of these taxa were observed in samples from Cores 23 through 20 of Hole 407. Globoquadrina venezuelana occurs in most samples from Cores 23 through 20 of Hole 407, and is common in Samples 23, CC through 22, CC. But Globoquadrina venezuelana is only present in low abundance in two samples and Globorotaloides suteri was not detected in any Zone N 7 or N 8 assemblages of Hole 408.

I do not think all these differences can be explained by dissolution effects at Site 407 . It seems more likely that part of the lower Miocene (and perhaps part of the middle Miocene, see below) is absent in Hole 407, and samples from Cores 23 through 20 are interpreted as being correlative with lower Zone N 7. My interpretations, however, conflict with the interpretations derived from calcareous nannofossil data (see Steinmetz, this volume), which suggest assignment of Sample 20, CC, to the middle Miocene.

Stratigraphically diagnostic taxa are absent from Sample $19, \mathrm{CC}$, and on the basis of adjacent samples I have arbitrarily assigned it to the middle Miocene and ?Zones N9-N 11.

Globigerina druryi, G. pseudociperoensis, Globorotalia mayeri, and G. acrostoma are present in Samples 19-2, 
TABLE 5

Occurrence of Planktonic Foraminifers and Other Selected Constituents in Samples from Holes 410 and 410A

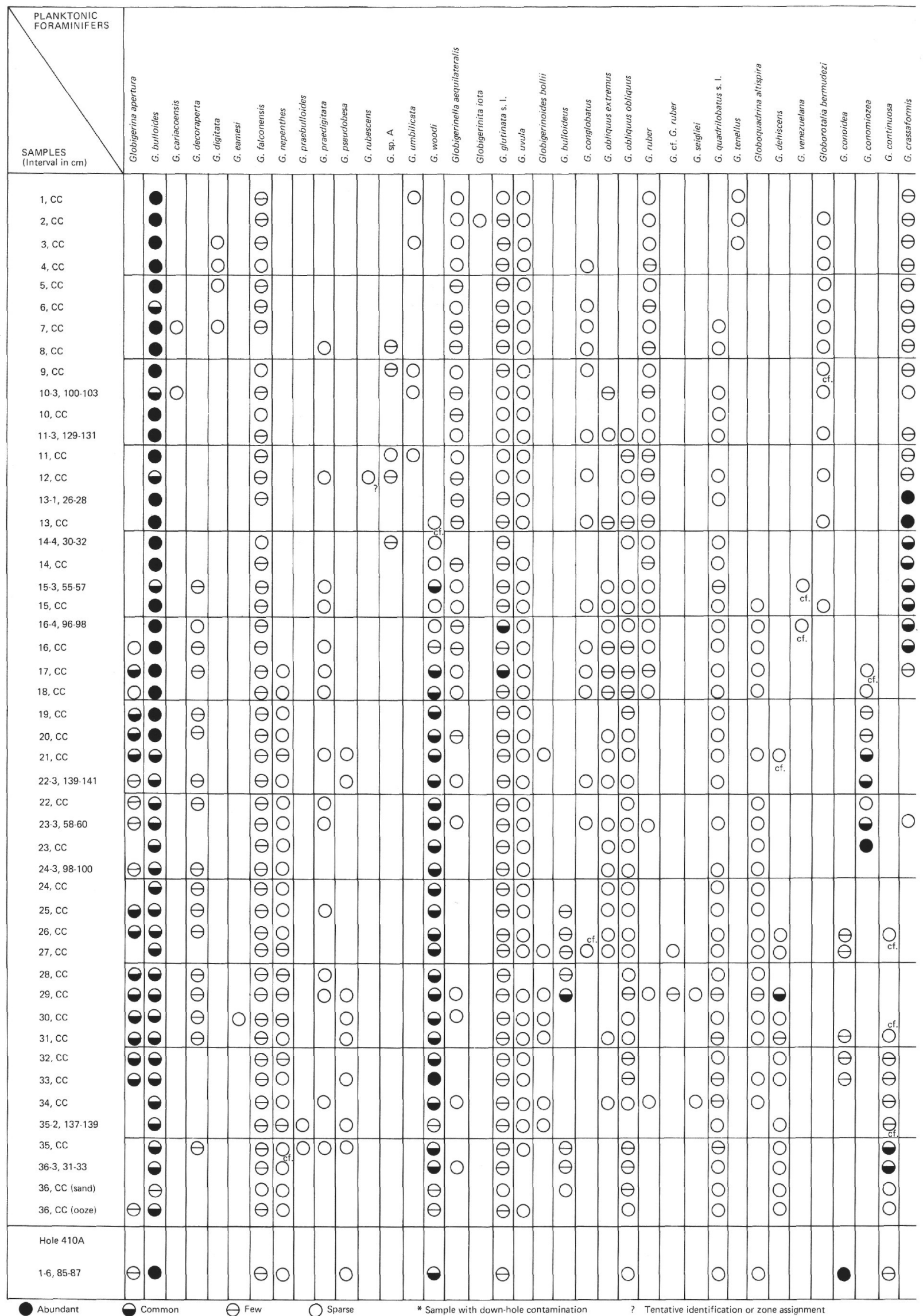




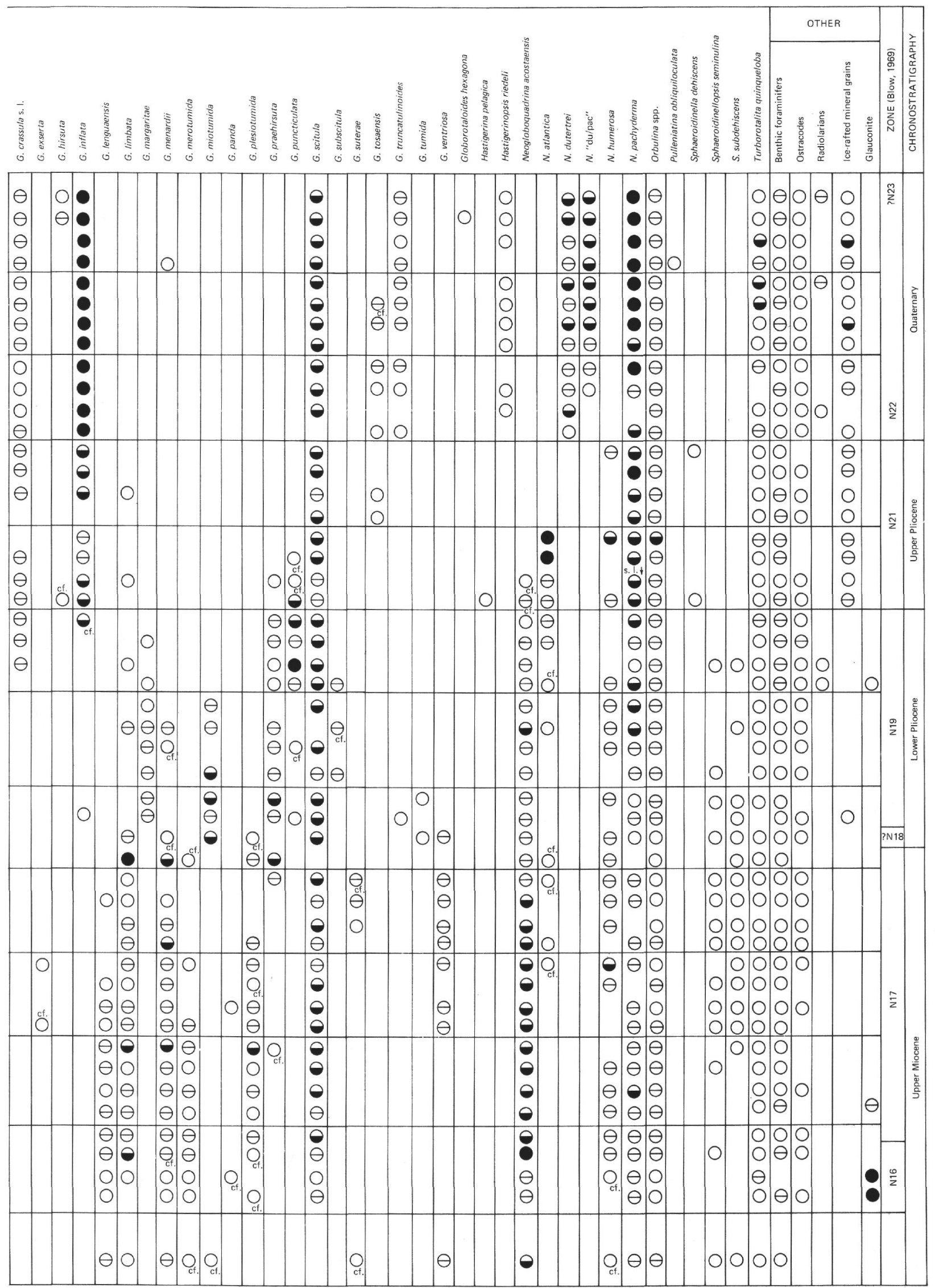


TABLE 6

Occurrence of Planktonic Foraminifers and Other Selected Constituents in Samples from Hole 441A and Hole 413 (Abundance estimates were not made for these samples)

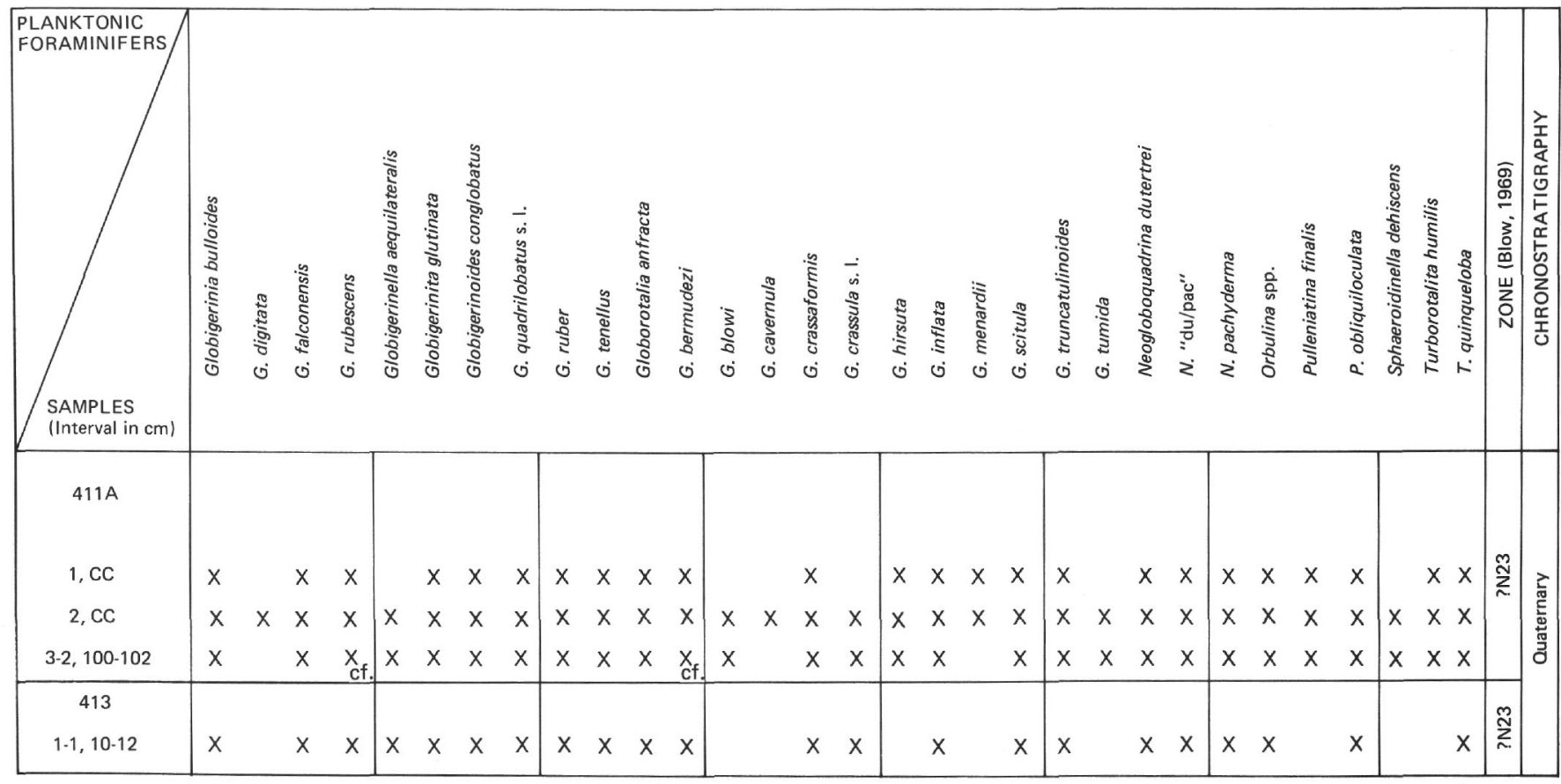

$102-104 \mathrm{~cm}$ through $18-3,21-23 \mathrm{~cm}$. On the basis of Globigerina druryi, this interval is assigned to Zones $\mathrm{N}$ 12-N 14. However, the absence of Globigerina nepenthes in these assemblages containing its ancestor $G$. druryi indicate that this interval may be only equivalent to Zones $\mathrm{N} 12-\mathrm{N}$ 13. Neogloboquadrina acostaensis, $N$. atlantica, $N$. pachyderma s.1., and common, typical Globigerina bulloides occur in Sample 17, CC. Dextrally coiling Neogloboquadrina atlantica is common in Sample 17, CC, but sinistrally coiling $N$. atlantica is common in Sample $17-3,22-24 \mathrm{~cm}$, along with a few quartz grains (ice rafted?) and common glauconite. Sample 17-2, 113-115 cm (not plotted on Table 2) contains an assemblage essentially identical to Sample 17-3, 22-24 cm. In Sample 16, CC, $N$. atlantica is poorly represented, and in Sample 16-3, $102-104 \mathrm{~cm}, N$. atlantica is sparse but sinistrally coiling specimens outnumber dextrally coiling specimens. No sediment was recovered in Core 15, and Sample 14, CC, marks the beginning of the first consistent occurrence of abundant sinistrally coiling Neogloboquadrina atlantica.

In the sub-boreal North Atlantic, common to abundant sinistrally coiling Neogloboquadrina atlantica is characteristic of the Pliocene - that is, insofar as the limits of the Pliocene can be determined (Berggren, 1972; Poore and Berggren, 1974, 1975a,b). Using this criterion, Sample 17, CC, is referable to the upper Miocene, and Sample $17-3,22-24 \mathrm{~cm}$, is Pliocene. This interpretation conflicts with the nannofossil determinations which indicate that Sample 16, CC, is no younger than upper Miocene.

Clearly there is an unconformity between Samples 18-3, $21-23 \mathrm{~cm}$, and 17, CC (at least one, if not several, foraminiferal zones are absent). This unconformity probably coincides with the abrupt change (upwards) from siliceous nannofossil chalk to nannofossil chalk in the upper part of Core 18 (see Site report). The glauconite in Samples $17, \mathrm{CC}$ through $16, \mathrm{CC}$, and the few quartz grains in Sample $17-3,22-24 \mathrm{~cm}$, and 17-2, 113-115 cm, indicate reworking and transport of material by bottom currents. I further suspect that the Miocene nannofossils in Sample 16, $\mathrm{CC}$, are also reworked. Thus the Miocene/Pliocene boundary on Table 2 and Figure 2 is placed between Samples 17, CC, and 17-3, 22-24 cm.

Neogloboquadrina atlantica, N. pachyderma s.1. and s.s., and Globigerina bulloides are common components of Pliocene assemblages from Hole 407. Globorotalia puncticulata is present from Sample 11-3, $42-54 \mathrm{~cm}$, through Sample 8-2, 63-65 cm, and $G$. inflata occurs sporadically upward from Sample 7, CC. On the basis of these occurrences, the lower/upper Pliocene boundary is drawn below Sample 7, CC. According to the foraminifer evidence, the Pliocene/Quaternary boundary is between Samples 6, CC, and 6-2, 22-24 cm, since the last good representative of Neogloboquadrina atlantica is in Sample 6 , CC. Following the nannofossil evidence, this boundary would be lower, between Cores 6 and 7. Similarly, the lower/upper Pliocene boundary is at least one core lower according to the nannofossil data (see Steinmetz, this volume). Regardless of which interpretation one accepts, the glacial Pliocene section at Hole 407 is extremely thin, and it is apparent that part of the upper Pliocene and perhaps part of the Quaternary is absent (ice-rafted mineral grains in Samples 8, CC, and 9, CC, recorded in Table 2, are accompanied by "modern" Neogloboquadrina pachyderma, and are considered downhole contaminants). Thus, there are at least three major unconformities in the sedimentary section recovered at Hole 407.

Quaternary assemblages of Hole 407 are dominated by Neogloboquadrina pachyderma s.s. A surprising 
TABLE 7

Occurrence of Planktonic Foraminifers and Other Selected Constituents in Samples from Hole 412

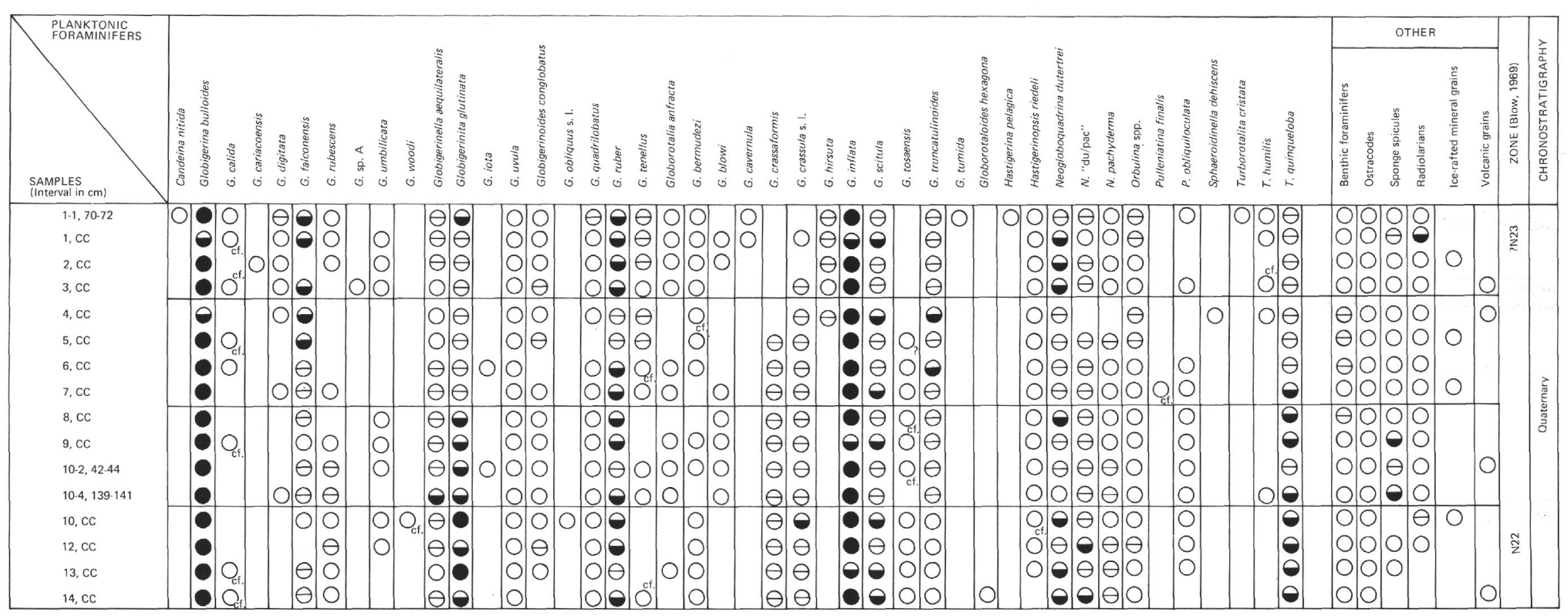

KEY

$\bigcirc$ Abundant

Few

$\ominus$ Sparse 


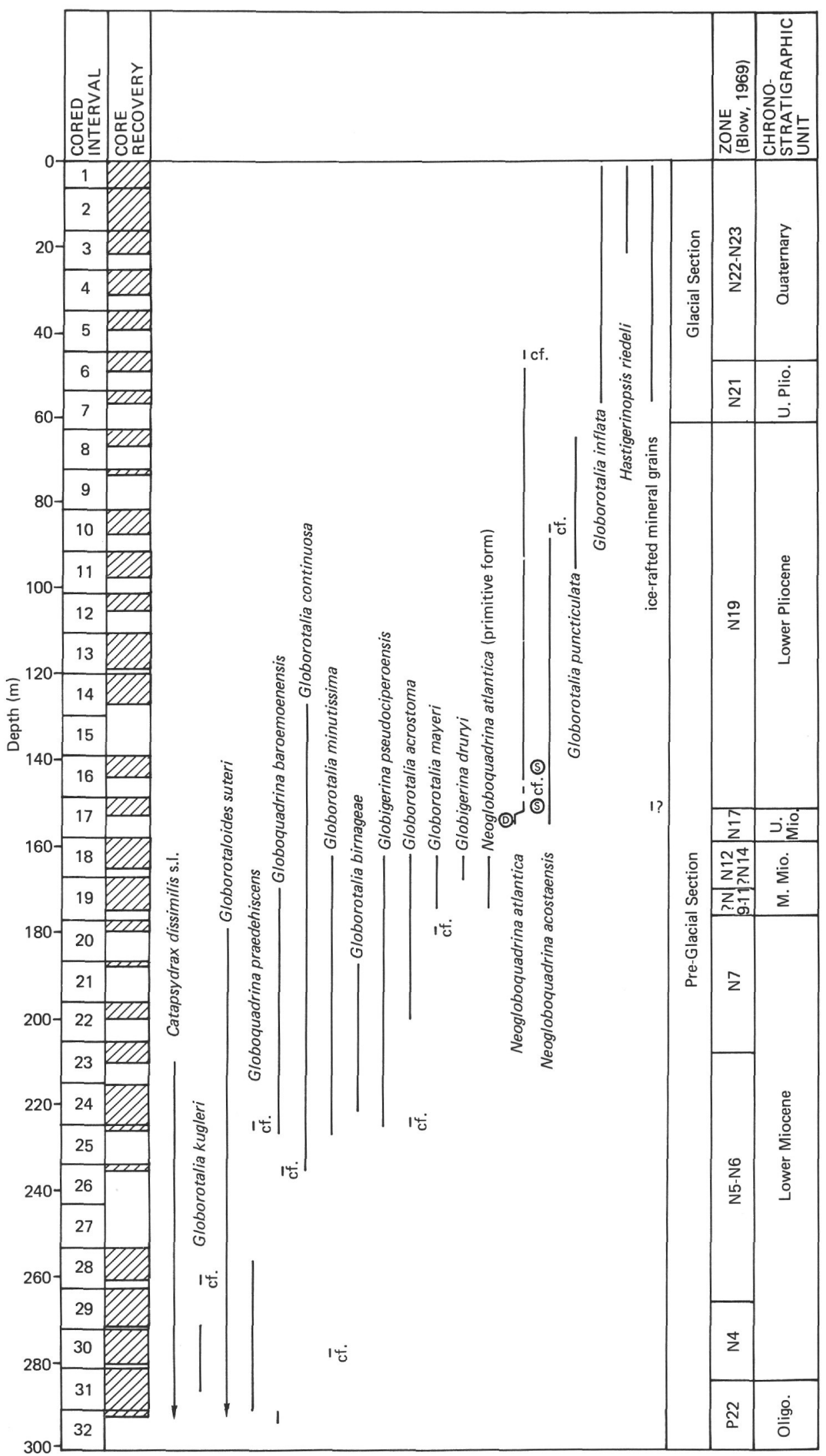

Figure 2. Range chart for selected taxa and ice-rafted mineral grains from Hole 407, Cores 32 through 1. 
occurrence is that of Hastigerinopsis riedeli in Cores 1 through 3. This taxon, originally described from occurrences in the Caribbean, was found at all provinces sampled during Leg 49, and so far seems to be restricted to the Quaternary. Thus, this distinctive, albeit minute, foraminifer has an extremely wide geographic distribution and may be useful for determining Quaternary foraminiferal assemblages in the absence of Globorotalia truncatulinoides.

The stratigraphic distribution of selected taxa, and ice-rafted mineral grains, and the zonal assignments for Cores 32 through 1 of Hole 407 are summarized on Figure 2.

\section{Site 408}

Site 408 , the middle site of the west-east transect of the Reykjanes Ridge, is on anomaly 6 (Table 1; Figure 1). Expected age for basement at this location is about 20 to 21 m.y. (Ryan et al., 1975).

Hole 408 was continuously cored to 361 meters sub-bottom, and basalt was first encountered at 321.5 meters. Some sediments intercalated with basalt were recovered from Hole 408, but they did not yield identifiable foraminifers.

Samples from immediately above basalt (Core 34) yield sparse to common planktonic foraminifers that are moderately well to poorly preserved. Glauconite is extremely abundant in samples from this core, and much of this glauconite is derived from fillings of foraminifers. Glauconite continues to be a common to abundant constituent of samples up to Sample 30, CC; however, foraminifers are somewhat more abundant and better preserved than in Core 34. Above Core 30, foraminifers are moderately well to well preserved and the abundance of foraminifers appears to vary inversely with the abundance of siliceous microfossils and volcanic ash.

Occurrence of planktonic foraminifers and other selected constituents of samples from Hole 408 are shown on Table 3.

The occurrence of Globigerinoides sicanus in Samples $33-4,130-132 \mathrm{~cm}$, through $32-2,112-114 \mathrm{~cm}$, is significant, since the range of this taxon is Zones $\mathrm{N} 8$ through lower N 9. Orbulina does not occur until Sample 30-4, 100-102 cm, however, so the Zone N 8/N 9 boundary (lower/middle Miocene boundary) is placed arbitrarily above Sample 32-2, 112-114 cm. Samples below 33-4, $130-132 \mathrm{~cm}$, are assigned to Zone N 7. The occurrences of Globigerina pseudociperoensis and Globigerinoides subquadratus in samples from Core 34 support this interpretation, because they first occur in Zone $\mathrm{N} 7$ or pre-Zone N 7 foraminiferal assemblages. Moreover, the occurrences of typical Globorotalia zealandica in Cores 33 and 32 indicate a position no lower than Zones $\mathrm{N} 7-\mathrm{N} 8$ (Berggren and Amdurer, 1974, fig. 1). The occurrences of Catapsydrax unicavus in Sample 33-4, 130-132 cm, and Globoquadrina praedehiscens as high as Sample 31-4, $100-102 \mathrm{~cm}$, are anomalous, in that both these taxa are thought to range no higher than Zone $\mathrm{N} 6$. It is likely that these taxa are reworked.

The nannofossil assemblages from this interval of Hole 408 are compatible with my interpretations. Thus, estimated age for sediments above basalt (N 7) is about $18 \mathrm{~m} . \mathrm{y}$., some $2 \mathrm{~m}$.y. younger than the expected age.

Assemblages from Samples 31, CC, through 30-4, $105-107 \mathrm{~cm}$, are not particularly age-diagnostic, and are dominated by Globigerina praebulloides s.1. These assemblages are correlated with Zones $\mathrm{N} 9$ through $\mathrm{N} 11$, on the basis of adjacent assemblages. It is not clear from the available data whether an unconformity is present between the lower and middle Miocene of Hole 408. If present, however, it is certainly of lesser extent than the one in Hole 407.

The first (lowest) occurrence of Globigerina druryi, in Sample 29, CC, and its sporadic occurrence through Sample 26-6, $19-21 \mathrm{~cm}$, indicates correlation of this interval with Zones N 12, N 13, and ?N 14. Specimens close to Globigerina nepenthes in Sample 26, CC, suggest that the top of this interval may be equivalent to Zone N 14 .

Samples from Core 25 contain Globorotalia mayeri and a generalized '"turborotaliid,', which I have referred to Globorotalia siakensis s.1., without Globigerina druryi. Zonal assignment of this core is uncertain. The absence of Globigerina druryi and the presence of Globorotalia siakensis s.1. suggest Zone N 14, but G. siakensis s.l. persists above this level, where it is found in association with Neogloboquadrina acostaensis, an upper Miocene taxon. Thus Core 25 is assigned to Zones N 14 and ?N 15.

On the basis of the first (lowest) Neogloboquadrina acostaensis in samples from Core 24 , closely followed by the establishment of $N$. pachyderma s.1., N. humerosa, and typical Globigerina bulloides in the foraminiferal assemblages of Core 23, Sample 24, CC, is considered to mark the base of the upper Miocene. Assemblages from Core 24 also contain Globorotalia siakensis s.1., which is restricted to Zone N 14 and pre-Zone N 14 assemblages, G. mayeri, glauconite grains, and in Sample 24, CC, a few quartz grains (recorded as ice-rafted [?] mineral grains on Table 3). It is possible that the glauconite and quartz grains are downhole contaminants - perhaps from a level near Core 5 , where glauconite is common to abundant - but if so, one would expect to see sinistrally coiling Neogloboquadrina atlantica (very abundant in Core 5) in these samples, especially Sample $24, \mathrm{CC}$, where glauconite is common. It is more likely that the occurrence of glauconite and quartz grains, as well as the possible occurrence of the middle Miocene foraminifer in upper Miocene sediments, are the results of transport and reworking by bottom currents. Further, this "'mixed" interval of Hole 408 is correlative with the unconformity noted between the middle and upper Miocene of Hole 407. Given the thickness of the upper Miocene section at Site 408, my interpretations suggest that this erosional event, which may be related to subsidence of the Iceland-Faeroe Ridge (1) began in the late middle Miocene or early late Miocene, (2) was of greater intensity and longer duration at Site 407 than at Site 408, and (3) prevented the deposition of sediments or periodically eroded sediments deposited at Site 407 during most of the late Miocene.

Common to abundant taxa in foraminiferal assemblages from the hundred-plus-meter upper Miocene section of Hole 408 are Globigerina bulloides, Neogloboquadrina pachyderma s.I., and N. acostaensis. Globigerina praebulloides s.1. and Globorotalia continuosa are persistent and 
sometimes common in samples up through Core 18, whereas dextrally coiling Neogloboquadrina atlantica becomes an abundant member of the assemblages in Cores 16 through 14 .

Sinistrally coiling Neogloboquadrina atlantica is abundant in Sample 13, CC, and dominates the foraminiferal assemblages up to Sample 5-1, 140-142 cm. As noted previously, the abundant occurrence of sinistrally coiling $\mathrm{Neo}$ globoquadrina atlantica in the sub-boreal North Atlantic is considered characteristic of the Pliocene. The Globorotalia puncticulata to $G$. inflata bioseries is poorly represented at Hole 408, and it is not possible to use it to detect the lower/ upper Pliocene boundary. The occurrence of ice-rafted mineral grains with Neogloboquadrina atlantica in Sample 5-1, 140-142 cm, does suggest an upper Pliocene assignment, and my preferred interpretation is to consider the Pliocene sediments below Sample 5-1, 140-142 cm, lower Pliocene. Because Quaternary turbidites were recovered in Cores 4 through 1, Sample 5-1, 140-142 cm, is the only sample assigned to the upper Pliocene.

This interpretation conflicts with nannofossil determinations (Steinmetz, this volume), which suggest an upper Pliocene assignment down to Sample 7, CC. At this writing this discrepancy has not been resolved. Regardless of the interpretation one prefers for placement of the lower/upper Pliocene boundary, the Pliocene glacial section here, as in Hole 407, is very thin, and it is apparent that part of the upper Pliocene and probably part of the Quaternary is missing in Hole 408. This hiatus in Holes 407 and 408 suggests a regional unconformity on the west flank of the Reykjanes Ridge between the Pliocene and the Quaternary. It is likely that this unconformity (or unconformities) is related to increased bottom current or turbidity current activity associated with one or more major upper Cenozoic climatic events.

The stratigraphic distribution of selected taxa, and icerafted mineral grains, and the zonal assignments for Cores 34 through 1 of Hole 408 are summarized on Figure 3.

\section{Site 409}

Site 409 , on anomaly $2^{\prime}$ near the crest of the Reykjanes Ridge, is the east point of the west-east transect (Table 1; Figure 1). Expected age for basement is $2.3 \mathrm{~m} . \mathrm{y}$.

After recovery of a nominal amount of (?) surficial sediment during the attempt to spud-in, Hole 409 was washed to 24.5 meters sub-bottom. Hole 409 was then cored continuously to 319 meters, and basalt was encountered at about 80 meters (within Core 7). Minor amounts of sediment recovered below basalt in Core 13 ( $130 \mathrm{~m}$ sub-bottom) did not yield foraminifers.

Foraminifers are few to common and poorly to moderately well preserved in samples from Core 7. In general, foraminifers become more abundant and are better preserved up-hole. The occurrence of planktonic foraminifers and other selected sample constituents from Hole 409 are shown on Table 4.

For a questionable occurrence of sinistrally coiling Neogloboquadrina atlantica in Sample 7-6, $53-55 \mathrm{~cm}$, the planktonic foraminiferal assemblages from Hole 409 suggest assignment to the Quaternary. On the basis of the first (lowest) occurrence of barred Gephyrocapsa spp., the nannofossil data suggest placement of the Pliocene/Quaternary boundary between Cores 7 and 6 (see Steinmetz, this volume). I have used the nannofossil data to place the upper Pliocene/
Quaternary boundary on Table 4. Assignment of Core 7 to the upper Pliocene is in agreement with the expected age for basement at Site 407 .

\section{$45^{\circ} \mathbf{N}$}

\section{Site 410}

Site 410 is in a sediment pond on the west side of the Mid-Atlantic Ridge at the western edge of anomaly 5 (Figure 1; Table 1). Expected age of basement is then approximately 10 m.y. (Ryan et al., 1975).

Hole 410 was continuously cored to 387.5 meters subbottom. Basement consisting of basalt limestone breccia was encountered at 340 meters sub-bottom. Recovery of the mainly nannofossil ooze and chalk above basement was relatively good, although spotty (average recovery $=65 \%$; see Figure 4), and except for samples adjacent to basalt (Core 36), planktonic foraminifers are abundant and well preserved throughout the sedimentary section.

A jammed core barrel forced termination of Hole 410 . After an offset of 110 meters, Hole 410A was washed to basement and coring in basalt was resumed. The first core recovered from Hole $410 \mathrm{~A}$ contained about 8.3 meters of sediment. Most of this sediment was probably picked up during one or more mudline penetrations, but the bottom meter of sediment represents basal or near basal sediments.

Occurrences and relative abundances of planktonic foraminifers and other selected sample constituents in samples from Holes 410 and $410 \mathrm{~A}$ are shown on Table 5.

\section{Hole 410}

Samples from Sample 36, CC, yield common but only moderately well preserved planktonic foraminifers. The foraminiferal assemblages from the ooze and sand units of the core catcher of Core 36 are very similar (Table 5), and both contain glauconite. Sand layers represent possible winnowing. Globorotalia merotumida and Neogloboquadrina acostaensis are present in samples from Core 36. Good examples of Globorotalia plesiotumida first occur in Sample 35, CC, whereas forms approaching $G$. plesiotumida are present in Samples 36, CC (ooze), and $36-3,31-33 \mathrm{~cm}$. Thus, Core 36 correlates with the upper part of Zone $\mathrm{N} 16$ and Core 35 is assigned to Zone N 17. For convenience, the boundary between the zones is placed just below Sample 35, CC. The paleontologic age estimate for the sediment overlying basalt is about 8.5 to $9.0 \mathrm{~m} . \mathrm{y}$., which is in close agreement with the expected age for basement of about $10 \mathrm{~m} . \mathrm{y}$.

Foraminiferal assemblages up through Sample 24-3, $58-60 \mathrm{~cm}$, are also referable to Zone N 17 . Globigerina bulloides, G. woodi, Globorotalia scitula, and Neogloboquadrina acostaensis are abundant components of assemblages from this interval. Other taxa which occur consistently but less abundantly include Globigerina falconensis, Globigerinita glutinata s.1., Globorotalia limbata, G. menardii, G. plesiotumida, Neogloboquadrina pachyderma s.1., and Turborotalita quinqueloba.

A primitive form of Globorotalia tumida occurs in Samples 23, CC, and 22, CC, and the first typical $G$. margaritae occurs in Sample 23-3, 58-60 cm (Table 5; Figure 4). These occurrences suggest a position close to the Miocene/Pliocene 


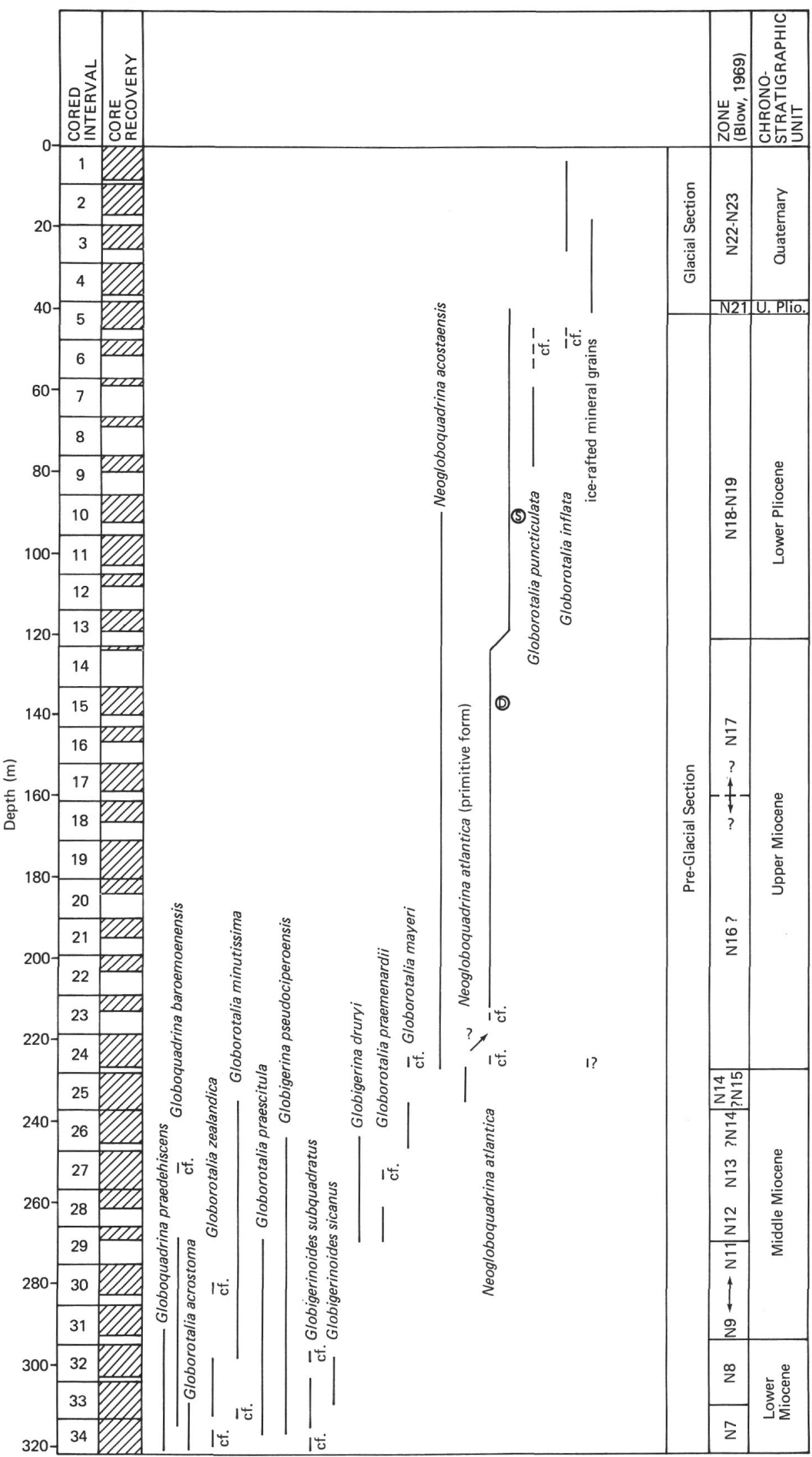

Figure 3. Range chart for selected taxa and ice-rafted mineral grains from Hole 408. 


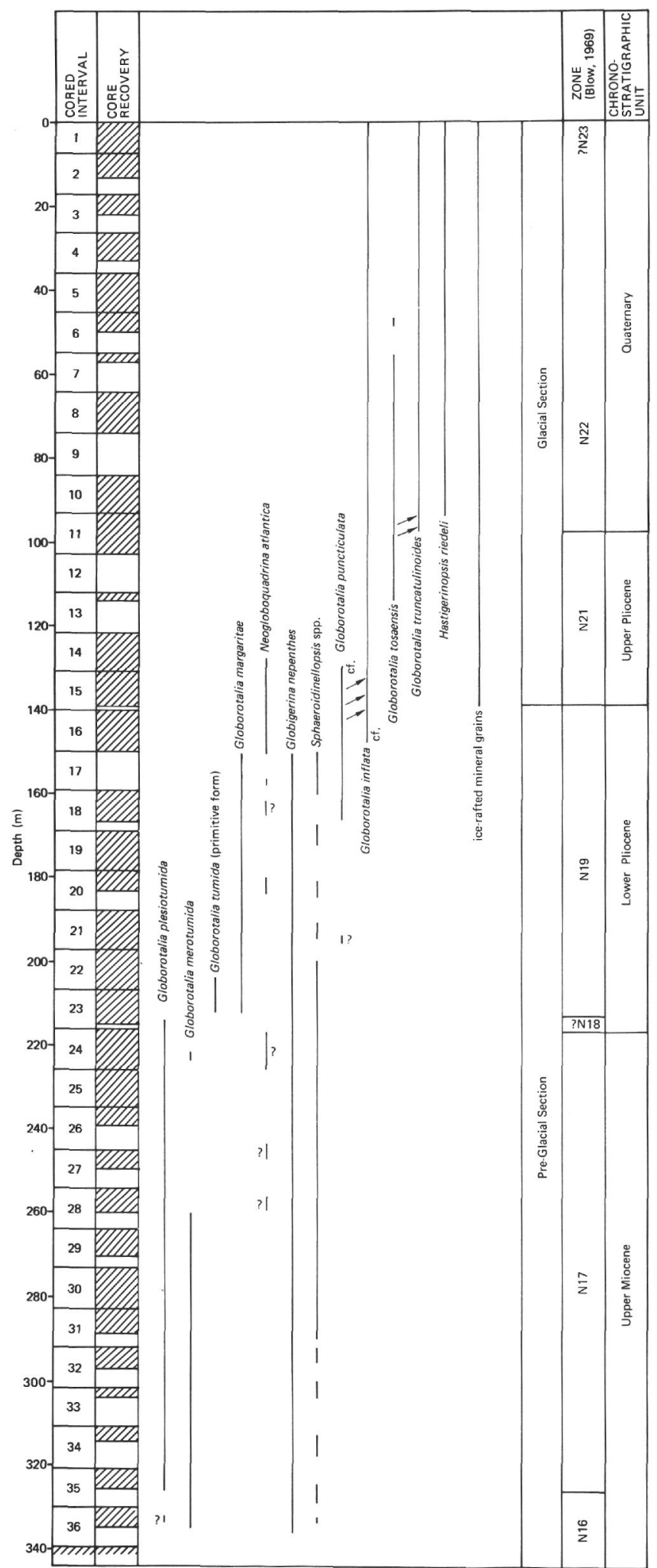

Figure 4. Range chart for selected taxa and ice-rafted mineral grains from Hole 410. boundary, and the Miocene/Pliocene boundary is tentatively placed just below Sample 23, CC. Sample 23, CC, however, contains taxa that are contaminants (presumably downhole contamination). For example, Globorotalia truncatulinoides, G. inflata, Neogloboquadrina pachyderma s.s., and a few angular quartz grains (ice-rafted?) present in the sample are clearly out of place. In addition, Globorotalia crassiformis and $G$. puncticulata are most probably downhole contaminants.

Globorotalia margaritae is a sparse but consistent component of the foraminiferal assemblage from Samples 23-3, $58-60 \mathrm{~cm}$, through 16, CC. Globigerina nepenthes is present up to Sample 17, CC, and Globorotalia puncticulata is well represented in Samples 18, CC, through 16-4, 96-98 cm. These occurrences indicate assignment of Samples 23, CC, through 16-4, 96-98 cm, to the lower Pliocene. Sample 23, $\mathrm{CC}$, is questionably assigned to Zone $\mathrm{N} 18$, and the remainder of the samples to Zone N 19. Globorotalia conomiozea is common in the lower part of this interval, and the first in-situ G. crassaformis is in Sample 17, CC.

It appears that the lowest occurrence of Globorotalia conomiozea represents a migrational event rather than an evolutionary event, since there is a significant gap between its first occurrence in Sample 23, CC, and the last occurrence of its ancestor G. conoidea in Sample 26, CC. Moreover, there is a growing body of evidence indicating that the first evolutionary appearance of $G$. conomiozea was in the late Miocene, about $6.5 \mathrm{~m} . \mathrm{y}$. ago (e.g., Poore and Berggren, 1975b; Ryan et al., 1975; D’Onofrio et al., 1975; Van Couvering et al., 1976). If my biostratigraphic interpretations are correct, the first occurrence of Globorotalia conomiozea in Hole 410 corresponds to an age closer to $5 \mathrm{~m}$.y. than to 6.5 m.y. The first in situ Globorotalia puncticulata and G. crassaformis may, however, represent evolutionary events, but additional work will be necessary to establish this.

An alternative position for the Miocene/Pliocene boundary in this hole is suggested by Steinmetz (this volume); he assigns nannofossil assemblages up through Core 18 to the upper Miocene nannofossil Zone NN 11. Placement of the Miocene/Pliocene boundary between Cores 18 and 17 requires a condensed lower Pliocene section or an unconformity within the lower Pliocene of Hole 410 (see below).

Forms transitional between Globorotalia puncticulata and $G$. inflata occur in Sample 16-4, 96-98 cm, in association with typical representatives of $G$. puncticulata. In the next higher sample $(15, \mathrm{CC}), G$. inflata is well established, and within the next sample $(15-3,55-57 \mathrm{~cm})$ the evolutionary replacement of $G$. puncticulata by $G$. inflata is essentially complete. The estimated age for the evolutionary first occurrence of $G$, inflata is $3.0 \mathrm{~m}$.y., coincident with the first appearance of ice-rafted mineral grains in the sub-boreal North Atlantic Basin, and approximates the base of upper Pliocene Zone N 21 (Berggren, 1972; Poore and Berggren, 1974, 1975b). The Zone N 19/N 21 boundary is therefore drawn just below Sample 15, CC, at the level where icerafted mineral grains judged to be in situ first occur in Hole 410. These data corroborate the results of DSDP Leg 12 that low-elevation glaciation in the Northern Hemisphere began in the early late Pliocene - and indicate that icebergs penetrated at least as far south as $45^{\circ} \mathrm{N}$ during the late Pliocene. 
The evolutionary occurrence of Globorotalia truncatulinoides from G. tosaensis (Sample 11-3, 129-131 cm) marks the base of the Quaternary. The first Globorotalia tosaensis, however represents a migrational event, since this taxon evolved at about the same time as Globorotalia inflata (Cita, 1973; Ryan et al., 1975, fig. 8).

Quaternary assemblages are dominated by Globigerina bulloides, Globorotalia inflata, and Neogloboquadrina pachyderma (dextral specimens $\geqslant$ sinistral specimens in most samples).

The stratigraphic ranges of selected taxa and ice-rafted mineral grains, as well as zonal assignments for Hole 410, are summarized in Figure 4. One point of interest is the distribution of Neogloboquadrina atlantica, which is poorly represented in samples from Hole 410, except for an interval just below and above the first occurrence of ice-rafted mineral grains in Sample 15, CC. This distribution indicates at least one significant southward displacement of surface water masses in the North Atlantic during the Pliocene, and probably correlates with the event represented in DSDP Hole 111 on Orphan Knoll (Poore and Berggren, 1974).

An apparent anomaly on Figure 4 is the last occurrence of Globorotalia margaritae in Sample 16, CC (expected age 3.3 m.y.), and Globigerina nepenthes in Sample 17, CC (expected age 3.7 m.y.), at the same level (Hays et al., 1969). This anomaly is at least in part caused by the extremely poor recovery in Core 17 and the convention of placing recovered material at the top of the cored interval. Figure 5 is an accumulation-rate diagram for Hole 410 . The diagram suggests that the cored interval for Core 17 , in which only a trace of sediment was recovered, is 3.3 to $3.6 \mathrm{~m}$.y. Following DSDP convention, I have plotted this sample (17, $\mathrm{CC}$ ) at the top of the cored interval on Figure 4. If the trace of sediment recovered in Core 17 is placed at the bottom of the cored interval, the distribution of these two taxa would be in agreement with their known stratigraphic ranges.

Extrapolation of a uniform accumulation rate to basement indicates an age of about $5.2 \mathrm{~m}$.y. for the Miocene/Pliocene boundary, and about $8.3 \mathrm{~m} . \mathrm{y}$. for the Zone $\mathrm{N} 16 / \mathrm{N} 17$ boundary, as biostratigraphically determined in Hole 410. These ages agree closely with the expected ages for these boundaries, $5.2 \mathrm{~m} . \mathrm{y}$. and $7.8 \mathrm{~m}$.y., respectively (Ryan et al., 1975). Extension of this accumulation rate to 340 meters sub-bottom (first basalt-limestone breccia) yields an age estimate of about $8.8 \mathrm{~m}$.y., which is younger than but compatible with the expected age of $10 \mathrm{~m}$.y. for basement at this location.

\section{Hole 410A}

A sample from the base of the sediments recovered from Hole 410A yielded an assemblage assignable to the upper Miocene (Table 5). The abundance of Globorotalia conoidea and $G$. lenguaensis in this sample suggests that it came from a level equivalent to Cores 31 to 33 , Hole 410 . Because this hole was washed to basement with a core liner in place, further study of these sediments was not undertaken.

\section{FAMOUS AREA}

\section{Site 411}

Site 411 is in a small sediment pond $10 \mathrm{~km}$ west of the median valley of the Mid-Atlantic Ridge, just on the old side of the Jaramillo normal polarity event (Figure 1; Table 1). Expected age for basement is thus approximately $1 \mathrm{~m} . \mathrm{y}$.

The first hole drilled at Site 411 was washed to basement with a core liner in place. Initial shipboard examination of a small amount of sediment from Core 1 revealed Quaternary foraminifers. The sediment could not be assigned to any particular depth; in fact, it could have been picked up during any of the 11 attempts to spud in (see Site Report for summary of operations). Consequently, this material was not examined further.

Upon termination of Hole 411, Hole 411A was offset 50 meters, and three discontinuous sediment cores were cut to basement. Planktonic foraminifers noted in several samples from Hole 411A (Table 6) indicate assignment to Zone N 23 of Blow (1969), and are compatible with the expected age of basement, approximately $1 \mathrm{~m} . \mathrm{y}$.

Except for a very thin layer of light gray nannofossil ooze at the bottom of Section 3-2, the sediment recovered is an orange-tinged foraminifer sand. During sample processing, relatively little material $\leqslant 63 \mu \mathrm{m}$ was noted, and most whole foraminifers were larger than $149 \mu \mathrm{m}$. This suggests transportation of coarse material into the basin from adjacent topographic highs, or winnowing, or some combination of the two.

\section{Site 412}

Site 412 is on the north side of the valley of Fracture Zone B, FAMOUS area. Magnetic surveys of this area indicate that crust immediately north of Site 412 is just younger than the Olduvai normal polarity event. Expected age for basement at Site 412 is thus about $1.6 \mathrm{~m} . \mathrm{y}$.

Hole 412 was discontinuously cored to 171.5 meters subbottom with an experimental bit designed to improve core recovery. Soon after basalt was encountered at 165.5 meters, the bit essentially disintegrated. Core recovery above basalt was in general good (average $\sim 70.8 \%$ ). Foraminifers are abundant and well preserved throughout the sedimentary section recovered from Hole 412.

Failure of the bit forced termination of Hole 412. After a bit change, Hole 412A was washed to basement and coring in basalt resumed. Sediments intercalated with basalt were recovered in Cores 3, 11, 12, and 14 of Hole 410A; the deepest occur approximately 118 meters below the first basalt. Foraminifers from these chalks were not studied, which, however, yields lower Quaternary nannofossils in agreement with the expected basement age.

Occurrences and relative abundances of planktonic foraminifers and other selected constituents in samples from Hole 412 are shown on Table 7.

Globorotalia truncatulinoides is present throughout the section, indicating an age no older than Quaternary. Globorotalia tosaensis occurs sporadically in the lower portion of the sedimentary section, and forms transitional between $G$. tosaensis and $G$. truncatulinoides occur in samples from Cores 14 through 10 . This suggests that the sediments above basalt in Hole 412 are lower Quaternary, and is in good agreement with the expected basement age.

Well-preserved discoasters occur in all smear slides made from Core 10 for shipboard sediment analysis. In addition, Sample 10, CC, contains sparse Globigerinoides obliquus s.1., which is not usually found in Quaternary sediments. Our 


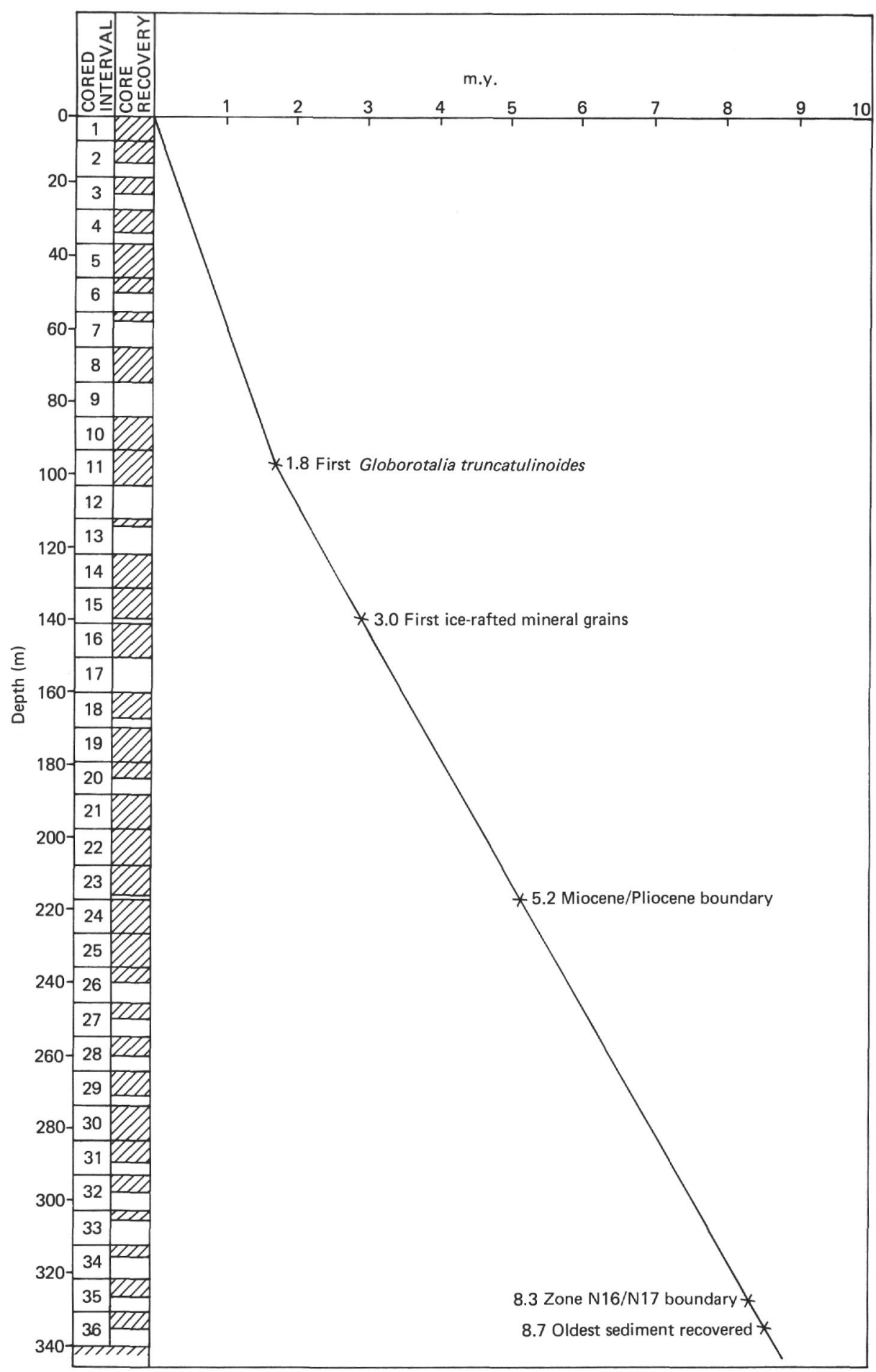

Figure 5. Sediment accumulation diagram for Hole 410. (Diagram was constructed assuming that (1) top of section is zero age, (2) first evolutionary occurrence of Globorotalia truncatulinoides is $1.8 \mathrm{~m} . y$. old, and (3) first occurrence of icerafted mineral grains is 3.0 m.y. old. Accumulation rate between points 2 and 3 was extrapolated to basement. The position of the Miocene/Pliocene boundary, based on biostratigraphic evidence, plots as about 5.2 m.y., which is in close agreement with the expected age of this boundary. Similarly, the Zone N16/N 17 boundary, which plots at approximately 8.3 m.y., is also in close agreement with the expected age for this boundary (Ryan et al, 1975). Note that the cored interval for Core 17, in which only a trace of sediment was recovered in the core catcher, falls in the range of 3.3 to 3.6 m.y. Thus, if this trace of sediment is placed at the bottom of the cored interval, the apparent anomaly of the last occurrences of Globigerina nepenthes (expected age 3.7 m.y.) and Globorotalia margaritae (expected age 3.3 m.y.), just below the first occurrence of ice-rafted mineral grains seen on Figure 4, disappears.] 
original shipboard interpretation was that Core 10 had sampled a slump of Pliocene sediments present in the Quaternary section. Subsequent examination of several other samples has revealed that Globorotalia truncatulinoides occurs throughout Core 10. Thus, this interval probably does not represent a slump of coherent Pliocene sediments, but rather is a zone of reworking.

\section{Site 413}

Site 413 is on the south side of the valley of Fracture Zone B. Hole 413 was washed to basement before the first core was cut. Quaternary foraminifers (Table 6) are present in "sediment" found surrounding basalt pieces in the first core. Well-preserved foraminifers are fairly common in the upper part of Core 1, and are associated with abundant angular grains of basalt, glass, and palagonite. The abundance of foraminifers decreases down the hole. The "sediment" recovered in Core 1 probably represents drill cuttings mixed with foraminifers derived from uphole.

No foraminifers could be reliably identified from limestone intercalated with basalt at this site.

\section{CRUISER-IRVING SEAMOUNT}

\section{Site 414}

Site 414, on the Cruiser-Irving seamount (Figure 1), was chosen as a site of opportunity after hurricane Emmy forced us to abandon the FAMOUS area. The first attempt to spud-in was unsuccessful because of the hardness of the sea bed. An offset was made but, before a second attempt could be made to spud-in, we were forced to abandon the site as hurricane Emmy also chose to visit the Cruiser-Irving seamount.

\section{ZONATION}

Before DSDP Leg 49, pre-Quaternary sediments of the sub-boreal North Atlantic were sparsely sampled. Coring during DSDP Leg 12 was discontinuous, and holes drilled on the Iceland-Faeroe Ridge during Leg 38 contained major unconformities; in general, microfossil assemblages encountered were sparse and poorly preserved. The Neogene sediments recovered at Sites 407 and 408 , which contain both siliceous and calcareous microfossils, will therefore be extremely valuable in future paleogeographic and paleoceanographic studies based on planktonic foraminifers and other microfossil groups.

The first step in any of these studies, however, is a system for intraregional and interregional correlation. Toward this end, a generalized 11-fold biostratigraphic subdivision of the Neogene (Miocene to Quaternary) of the high-latitude North Atlantic is shown on Figure 6. Occurrences of selected taxa that can be used to characterize planktonic foraminiferal assemblages at various levels in the Neogene are represented by stratigraphic distribution fields. The width of the distribution fields does not indicate relative abundance. For example, Quaternary Zone $\mathrm{K}$ is characterized by planktonic foraminiferal assemblages containing Globorotalia inflata and Neogloboquadrina pachyderma s.s., whereas upper Pliocene Zone $\mathbf{J}$ is characterized by assemblages with Globorotalia inflata, Neogloboquadrina pachyderma s.s. or s.l., and sinistral $N$. atlantica. Similarly, lower Miocene Zone $\mathrm{D}$ is characterized by assemblages containing Globigerina pseudociperoensis, Globigerinoides sicanus,

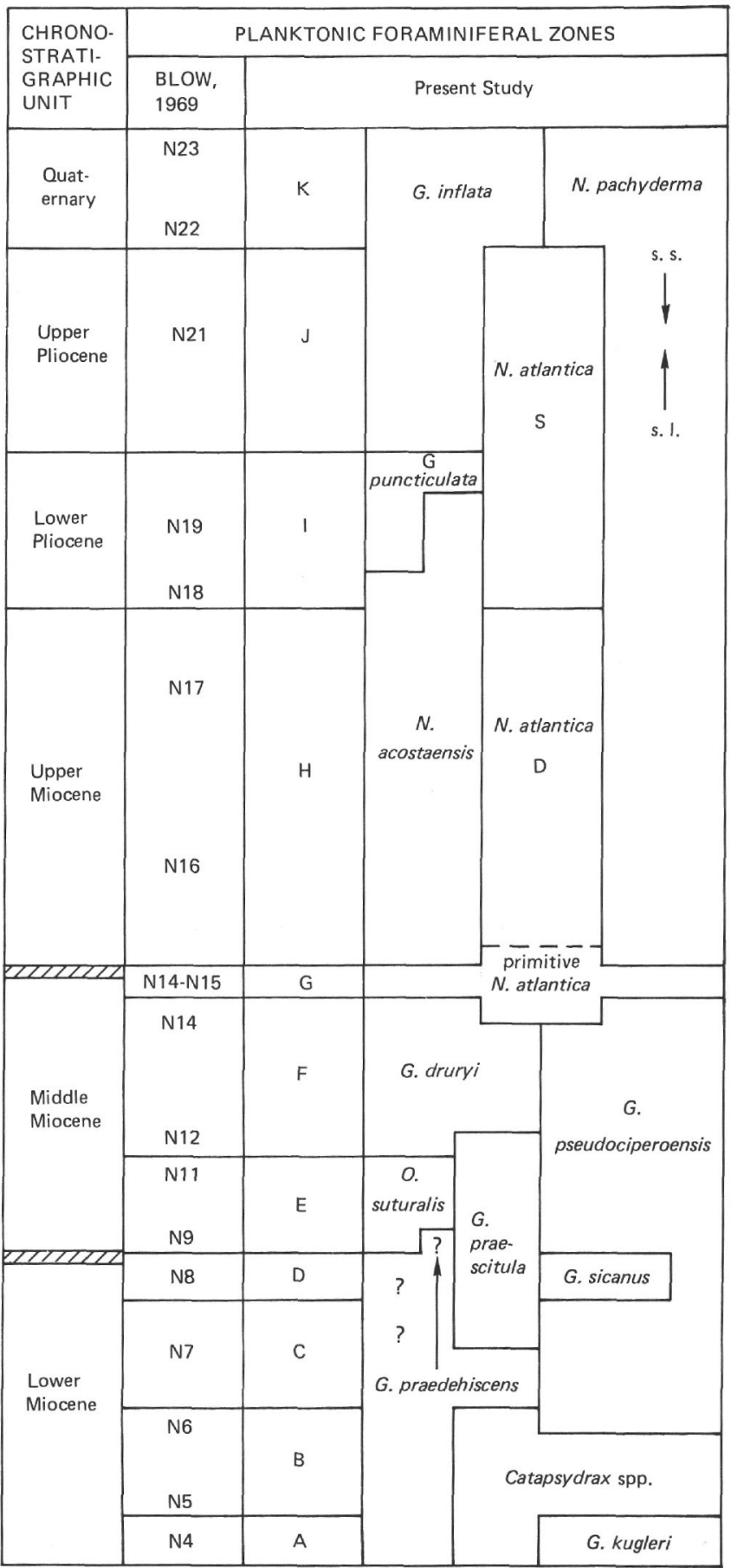

Figure 6. Informal biostratigraphic subdivision for highlatitude North Atlantic and suggested relationship to the standard zonation of Blow (1969). (Uncertainty in correlation of Blow's zonation with chronostratigraphic units is shown by bars between lower Miocene and middle Miocene and between middle Miocene and upper Miocene.)

and Globorotalia praescitula. The queried extension of Globoquadrina praedehiscens above Zone B allows for the possibility that specimens detected in Hole 408 may not be allochthonous occurrences, but rather may represent an up- 
ward extension of this taxon's range in extra-tropical regions.

Except for Orbulina suturalis, taxa were not observed outside their indicated field. This zonation incorporates data from Sites 407 and 408, as well as results from studies on sediments recovered during DSDP Leg 12.

Because the present study of planktonic foraminifers in Holes 407 and 408 is preliminary, the zonation is not formally defined or named. Correlations of informal Zones A-K with the standard zonation of Blow (1969), and thus to divisions of the Cenozoic, follows the rationale discussed under Sites 407 and 408 in the previous section.

\section{CORRELATION}

Figure 7 represents an attempt to correlate several Neogene planktonic foraminiferal zonations developed in tropical and extra-tropical regions. The zonation of Blow (1969), built in large part on the work of Bolli (1957a, b), has gained wide acceptance and is used as a standard. Other zonations are correlated here with that of Blow (1969), and thus with each other. Calibration of Blow's zonation to the Cenozoic time-scale follows Ryan et al. (1975). The following discussion pertains to the construction of Figure 7.

Correlation of column 1 with column 4 is taken from Figure 6 of this paper. Correlation of column 2 with column 4 is slightly modified from Poore and Berggren (1975b), in that the base of their Globorotalia puncticulata Zone is now considered to be definitely within the lower Pliocene and the base of their $G$. inflata Zone is taken as approximating the base of Zone N 21.

The zonation of Bizon and Bizon (1972) was developed for the Mediterranean basin. Reliable correlation points between their zonation and Blow's (columns 3 to 4) include the last occurrences of Globorotalia kugleri and Catapsydrax dissimilis s.1., and the first occurrences of Orbulina, Neogloboquadrina acostaensis, Globorotalia margaritae, and $G$. truncatulinoides. Placement of other zonal boundaries, especially those of the middle Miocene, is less certain.

The zonation of Jenkins and Orr (1972) for the eastern equatorial Pacific is shown in column 5. Reliable correlation points between their zonation and Blow's include the last occurrences of Globorotalia kugleri and Catapsydrax dissimilis s.l. and the first occurrences of Globigerinoides bisphericus (=G. sicanus), Globorotalia peripheroacuta, $G$. plesiotumida, and Sphaeroidinella dehiscens (i.e., S. dehiscens immatura).

The lack of resolution across the middle/upper Miocene boundary in the zonation of Jenkins and Orr (1972) results from sparse assemblages in this interval, caused by dissolution. Available nannofossil data from DSDP cores studied by Jenkins and Orr (1972) were used to estimate placement of some of the other zonal boundaries. For example, in DSDP Hole 77B, the top of the Globigerinoides fistulosus Zone coincides approximately with the last occurrence of Discoaster brouweri (Bukry, 1972), considered to be close to the Pliocene/Pleistocene boundary. Further, the base of the Globigerinoides fistulosus Zone in Hole 77B coincides with the top of the Reticulofenestra pseudoumbilica Zone of Bukry (1971) (Bukry, 1972). This boundary is equivalent to the Zone NN 15/NN 16 boundary of Martini (1971), which correlates with the base of foraminiferal Zone N 21
(Berggren and Van Couvering, 1974). Thus, the Globigerinoides fistulosus Zone is equivalent to Zone N 21.

The base of the Globoquadrina altispira Zone and the base of the Globorotalia fohsi lobata Zone in Hole 77B occur within the Discoaster exilis Zone (Bukry, 1972). The Discoaster exilis Zone of Bukry (1971) is equivalent to Zones NN 6 and NN 7 of Martini (1971), which are in turn correlated with Blow's Zones N 10 to N 12 and lower N 13. These data are compatible with my placement of the Globorotalia fohsi lobata Zone in Figure 7.

Correlation of Kennett's (1973) zonation for the warmsubtropical southwest Pacific with Blow's zonation is aided, in part, by the nannofossil determinations of Bukry (1973b). Kennett (1973) considers the base of his Orbulina suturalis Zone, although not formally defined, to be marked by the last occurrence of Praeorbulina glomerosa curva, which according to Blow (1969) is at the Zone N 8/N 9 boundary. Further, in Hole 206, the first occurrence of Globorotalia mayeri, defining the base of Kennett's $G$. mayeri Zone, is accompanied by the first occurrence of $G$. peripheroacuta, which defines the base of Zone N 10. The Orbulina suturalis Zone is thus equivalent to Zone N 9. In Hole 206, the lowest occurrence of Globigerina nepenthes is within the Globorotalia mayeri Zone, indicating that this zone extends at least into Zone 14. The base of the overlying Globorotalia continuosa Zone is within the Discoaster hamatus Zone of Bukry (1973a; = NN 9 of Martini, 1971), which correlates with foraminiferal Zones N 14 and N 15. In Hole 208, the boundary between the Globorotalia continuosa and Globigerina nepenthes Zones is within an interval probably corresponding to the upper Miocene Discoaster neohamatus to lower D. quinqueramus Zones of Bukry (1973a). Moreover, the lowest occurrence of Neogloboquadrina acostaensis is in the Globorotalia continuosa Zone, indicating that this zone straddles the Zone N 15/N 16 boundary. I have therefore arbitrarily correlated the base of the Globorotalia continuosa Zone with the Zone N 14/N 15 boundary, and tentatively place the base of the Globigerina nepenthes Zone at a level in mid-Zone N 16.

The base of the Globorotalia conomiozea Zone is within Core 13 of Hole 208. As summarized earlier in this paper, the evolutionary first occurrence of this taxon is considered to be within the upper Miocene at a level estimated to be about 6.5 $\mathrm{m} . \mathrm{y}$. old. The assignment of nannofossil assemblages up to Section 208-12-6 to the upper part of the Discoaster quinqueramus Zone is in good agreement with this interpretation.

The lowest occurrences of Globorotalia margaritae and G. truncatulinoides in Kennett's zonation are used as reliable markers for the Miocene/Pliocene boundary and the Pliocene/Quaternary boundary, respectively. Remaining zonal boundaries are tentatively sketched in on Figure 7.

The final zonation included in Figure 7 was developed in New Zealand by Jenkins (1971). Globorotalia kugleri occurs in the lower, but not the basal, Globigerina woodi connecta Zone. This occurrence suggests that this zone extends down into the Oligocene. Placement of the Globigerina woodi connecta/Globigerinoides trilobus trilobus Zone boundary with respect to Blow's zonation is difficult but can be indirectly estimated. Hornibrook and Edwards (1971) note that the last occurrence of Globigerina woodi connecta is some- 


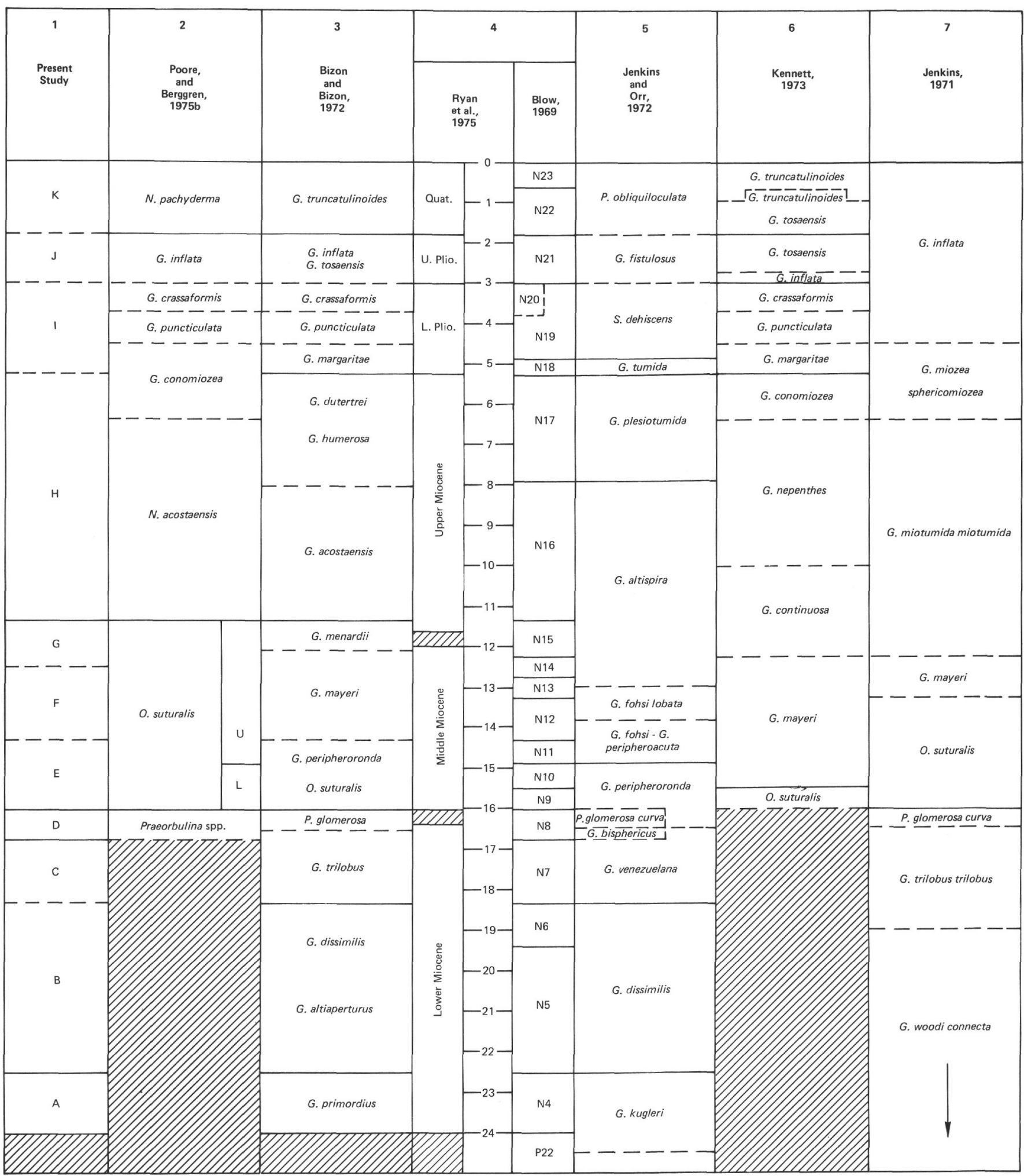

Figure 7. Correlation of selected Neogene planktonic foraminiferal zonations developed in tropical and extra-tropical regions. [Correlations indicated by dashed lines are considered less reliable than those indicated by solid lines. The zonation of Blow (1969) is used as the standard. Calibration of Blow's zonation to the Cenozoic time-scale follows Ryan et al. (1975). Uncertainty in correlation of Blow's zonation with chronostratigraphic units is shown by bars between lower Miocene and middle Miocene and between middle Miocene and upper Miocene. See text for discussion.] 
times associated with the first (lowest) occurrence of Sphenolithus heteromorphus. The lowest occurrence of Sphenolithus heteromorphus is in nannofossil Zone NN 4, which correlates with foraminiferal Zone N 7. In New Zealand, the last occurrence of Globigerina woodi connecta is in the lower Globigerinoides trilobus trilobus Zone (Jenkins, 1971). These data suggest placement of the Globigerina woodi connecta/Globigerinoides trilobus trilobus Zone boundary just below the Zone N 6/N 7 boundary. The occurrence in the Globigerinoides trilobus trilobus Zone of Globorotalia zealandica s.s., which is considered to be typical of Zone N 7 and Zone N 8 assemblages (Berggren and Amdurer, 1973), supports this interpretation.

The first occurrences of Praeorbulina glomerosa curva and Orbulina suturalis mark the next two successive zonal boundaries, and correlation of these levels to Blow's zonation is straightforward.

The occurrence of Globigerina decoraperta (probably $G$. druryi of my usage) in the upper part of the Orbulina suturalis Zone, and the occurrence of keeled representatives of the Globorotalia fohsi plexus in the lower Globorotalia mayeri mayeri Zone, suggests that the base of Jenkins's $G$. mayeri mayeri Zone is well up within the middle Miocene so this base is placed at the Zone $\mathrm{N} \mathrm{12/N} 13$ boundary. The top of this zone is arbitrarily considered to be equivalent to the top of Kennett's Globorotalia mayeri Zone.

Because of the occurrence of Globorotalia conomiozea in the $G$. miozea sphericomiozea Zone, the base of the $G$. miozea sphejicomiozea Zone is correlated with the base of Kennett's $G$. conomiozea Zone. Similarly, the base of the Globorotalia inflata Zone (= first $G$. puncticulata) is correlated with the base of Kennett's G. puncticulata Zone.

Clearly, the correlations suggested in Figure 7 need to be tested for reliability and chronostratigraphic significance; they do serve, however, as a starting point for future work.

\section{TAXONOMIC NOTES}

The original references to all species identified and plotted on Tables 2 through 7 are listed below. In addition, discussion and comments are provided for informally recognized and other selected taxa. Specimens illustrated on Plates 1 through 20 have been deposited with the U.S. National Museum, Washington, D.C.

\section{Candeina nitida d'Orbigny}

Candeina nitida d'Orbigny, 1839a, p. 108, pl. 2, fig. 27 and 28.

\section{Cassigerinella chipolensis (Cushman and Ponton) \\ (Plate 20, Figures 3, 4)}

Cassidulina chipolensis Cushman and Ponton, 1932, pl. 15, fig. 2.

Catapsydrax dissimilis ciperoensis (Blow and Banner) (Plate 15, Figure 5)

Globigerinita dissimilis ciperoensis Blow and Banner, 1962, p. 107, pl. 14, fig. A through C.

Catapsydrax dissimilis dissimilis (Cushman and Bermudez) (Plate 15, Figure 4)

Globigerina dissimilis Cushman and Bermudez, 1937, p. 25, pl. 3, fig. 4 through 6.

\section{Catapsydrax gortanii gortanii Borsetti}

Catapsydrax gortanii Borsetti, 1959, p. 205, pl. 1, fig. 1.
Catapsydrax stainforthi Bolli, Loeblich, and Tappan (Plate 15, Figures 1-3)

Catapsydrax stainforthi Bolli, Loeblich, and Tappan, 1957, p. 36, pl. 7, fig. 11.

My records of Catapsydrax stainforthi in Oligocene sediments of Hole 407 are in conflict with the presumed lower Miocene occurrence of this taxon (e.g., Blow, 1969; Stainforth et al., 1975). At the present time I have no explanation for this anomalous occurrence.

Catapsydrax unicavus Bolli, Loeblich, and Tappan

Catapsydrax unicavus Bolli, Loeblich, and Tappan, 1957, p. 37, pl. 7, fig. 9.

Chiloguembelina cubensis (Palmer)

(Plate 20, Figures 1, 2)

Guembelina cubensis Palmer, 1934, p. 74, fig. 1 through 6.

Chiloguembelina victoriana Beckmann

Chiloguembelina victoriana Beckmann, 1957, p. 91, pl. 21, fig. 19 and 20, test-fig. 15 , No. 46 through 48 .

Globigerina angiporoides Hornibrook (Plate 20, Figures 5, 6)

Globigerina angiporoides Hornibrook, 1965, p. 835, fig. 1 and 2 .

Globigerina anguliofficinalis Blow (Plate 15, Figure 6)

Globigerina anguliofficinalis Blow, 1969, p. 379, pl. 2, fig. 1 through 5.

Globigerina angustiumbilicata Bolli

Globigerina ciperoensis angustiumbilicata Bolli, 1957a, p. 109, pl. 22, fig. 12 and 13.

Globigerina apertura Cushman

(Plate 13, Figures 11, 12)

Globigerina apertura Cushman, 1918, p. 57, pl. 12, fig. 8.

Globigerina bulbosa LeRoy

(Plate 14, Figures 10, 11)

Globigerina bulbosa LeRoy, 1944, p. 39, fig. 26 and 27.

Globigerina bulloides d'Orbigny

Globigerina bulloides d'Orbigny, 1826, p. 277.

Globigerina calida Parker

Globigerina calida Parker, 1962, p. 221, pl. 1, fig. 9 through 13, 15.

\section{Globigerina cariacoensis Rögl and Bolli}

Globigerina megastoma cariacoensis Rögl and Bolli, 1973, p. 564, pl. 2, fig. 1 through 10 ; pl. 12 , fig. 5 and 6 ; text-fig. 4 .

Globigerina ciperoensis Bolli

Globigerina ciperoensis Bolli, 1954, p. 1, fig. 3 through 6.

Globigerina connecta Jenkins

(Plate 12, Figures 6, 9)

Globigerina woodi connecta Jenkins, 1964, p. 72, text-fig. 1.

\section{Globigerina decoraperta Takayanagi and Saito}

(Plate 12, Figures 7, 8)

Globigerina druryi decoraperta Takayanagi and Saito, 1962, p. 85, pl. 28 , fig. 10.

Globigerina digitata Brady

(Plate 2, Figures 3, 6)

Globigerina digitata Brady, 1879, p. 286. 
Globigerina druryi Akers

(Plate 12, Figures 1-3)

Globigerina druryi Akers, 1955, p. 654, pl. 65, fig. 1.

Globigerina eamesi Blow

Globigerina eamesi Blow, 1959, p. 176, pl. 9, fig. 39.

Globigerina euapertura Jenkins

Globigerina euapertura Jenkins, 1960, p. 351, pl. 1, fig. 8 .

Globigerina falconensis Blow

(Plate 12, Figures 10-12)

Globigerina falconensis Blow, 1959, p. 177, pl. 9, fig. 40 and 41 .

\section{Globigerina galavisi Bermudez}

Globigerina galavisi Bermudez, 1961, p. 1183, pl. 4, fig. 3.

\section{Globigerina nepenthes Todd}

(Plate 12, Figures 4, 5)

Globigerina nepenthes Todd, 1957, p. 301, pl. 78, fig. 7.

Globigerina obesa (Bolli)

Globorotalia obesa Bolli, 1957a, p. 119, pl. 29, fig. 2 and 3.

Globigerina ouachitaensis Howe and Wallace (Plate 20, Figure 7)

Globigerina ouachitaensis Howe and Wallace, 1932, p. 83, pl. 12, fig. 18 and 19.

Globigerina ouachitaensis s.1. and G. praebulloides s.l. are the most common taxa in Oligocene sediments of Hole 407. I have included forms approaching Globigerina gnaucki Blow and Banner with $G$. ouachitaensis s.s. on Table 2.

\section{Globigerina praebulloides Blow}

Globigerina praebulloides Blow, 1959, p. 180, pl. 8, fig. 47; pl. 9, fig. 48. Globigerina praebulloides exhibits considerable variability in Oligocene through middle Miocene sediments recovered from Holes 407 and 408. In fact, some members of the population from the Oligocene of Hole 407 closely resemble the younger Globigerina bulloides. My observations are similar to those of Jenkins (1971), and suggest that clear separation of Globigerina praebulloides and $G$. bulloides may be difficult in extratropical regions.

No attempt was made during this study to separate Globigerina leroyi Blow and Banner and $G$. occlusa Blow and Banner from G. praebulloides.

\section{Globigerina praedigitata Parker}

Globigerina praedigitata Parker, 1967, p. 151, pl. 19, fig. 5 through 8 .

Globigerina pseudobesa (Salvatorini)

Turborotalia pseudobesa Salvatorini, 1966, p. 10, pl. 2, fig. 6 through 15.

\section{Globigerina pseudociperoensis Blow}

(Plate 14, Figures 8, 9)

Globigerina praebulloides pseudociperoensis Blow, 1969, p. 381, pl. 17, fig. 8 and 9.

\section{Globigerina rubescens Hofker}

(Plate 2, Figures 1, 2)

Globigerina rubescens Hofker, 1956, p. 234, pl. 35, fig. 18 through 21.

Globigerina sp. A

(Plate 19, Figures 5-12)

This thin-walled, non-spinose(?) form has 4 to 6 chambers in the ultimate whorl and 5 chambers in the penultimate whorl. The umbilicus is open and deep, and varies considerably in size. The aperture is umbilical to extraumbilical-umbilical, and a delicate but well-defined lip is present on most specimens. End members of the population develop a "tear-drop" ultimate chamber, and thus resemble Turborotalita quinqueloba. The spiral side may be flat to slightly convex. This form is abundant in several samples from Hole 409. It occurs sporadically and in low abundance in upper Miocene through Quaternary sediments recovered elsewhere during Leg 49.

Globigerina sp. B

(Plate 15, Figures 11, 12)

The radially elongated chambers and small, lipped aperture characterize this taxon. Some representatives of this form may have supplementary apertures, but poor preservation and paucity of specimens prevented confident evaluation of this feature. Globigerina sp. B was only encountered in upper Oligocene sediments of Hole 407.

\section{Globigerina tripartita Koch}

Globigerina bulloides var. tripartita Koch, 1926, p. 746, fig. 21.

\section{Globigerina umbilicata Orr and Zaitzeff \\ (Plate 14, Figure 12)}

Globigerina umbilicata Orr and Zaitzeff, 1971, p. 18, pl. 1, fig. 1 through 3.

\section{Globigerina woodi Jenkins \\ (Plate 13, Figures 1 - 10)}

Globigerina woodi Jenkins, 1960, p. 352, pl. 2, fig. 2.

Globigerina woodi is extremely variable in the lower Miocene of Hole 408, especially in samples from Core 32 . The aperture of some specimens is constricted near the umbilicus, resulting in a "key-hole" shape (i.e., $G$. woodi [ of Poore and Berggren, 1975b]). Others have a very broad semicircular aperture, like that of Globigerina apertura, and still others have almost parallel-sided apertures placed asymmetrically over the antepenultimate chamber of the final whorl, so that the aperture becomes extraumbilicalumbilical. These variants of Globigerina woodi are similar to Globigerina sallentina Dallan, Giannelli, and Salvatorini, described from occurrence in the lower Pliocene of Italy.

\section{Globigerinella aequilateralis (Brady)}

(Plate 1, Figure 3)

Globigerina aequilateralis Brady, 1879, p. 285.

\section{Globigerinita glutinata (Egger) s.l.}

Globigerina glutinata Egger, 1893, p. 371, pl. 13, fig. 19 through 21.

For the purposes of this report, Globigerinita ambitacrena (Loeblich and Tappan), G. incrusta Akers, G. naparimaensis Brönnimann, and Globigerina juvenilis Bolli are recorded under Globigerinita glutinata s.1.

\section{Globigerinita iota Parker}

Globigerinita iota Parker, 1962, p. 250, pl. 10, fig. 26 through 30.

\section{Globigerinita martini Blow and Banner}

Globigerinita Martini Blow and Banner, 1962, p. 110, pl. 14, fig. o-, v-x.

Specimens referred to Globigerinita martini are sparse and too poorly preserved to allow differentiation of $G$. martini martini from $G$. martini scandretti.

\section{Globigerinita praestainforthi Blow}

(Plate 15, Figures 7, 8)

Globigerinita stainforthi praestainforthi Blow, 1969, p. 383, pl. 25 , fig. 3 through 5.

I doubt that this taxon is the ancestor of Catapsydrax stainforthi. Preliminary SEM study of the test-surface ultrastructure suggests this form is closely related to the Globigerinita glutinata group. The same conclusion was reached by Stainforth et al. (1975).

\section{Globigerinita sp. (spp.)}

Globigerinita sp. (spp.) of Poore and Berggren, 1975b, p. 292, pl. 5, fig. 1 through 5 .

This designation is used for a group of forms noted by Poore and Berggren (1975b) in upper Miocene-lower Pliocene sediments of Hole 116 (Hatton-Rockall Basin). The group seems to have a similar range in Hole 408, but was not detected in Hole 407.

\section{Globigerinita uvula (Ehrenberg)}

Pylodexia uvula Ehrenberg, 1861, p. 308.

I concur with Parker (1962) in placing Globigerina bradyi Wiesner in synonymy with Globigerinita uvulva . 


\section{Globigerinoides bellii Blow}

Globigerinoides bollii Blow, 1959, p. 189, pl. 10, fig. 65.

Globigerinoides bulloideus Crescenti (Plate 1, Figures 7-9)

Globigerinoides bulloideus Crescenti, 1966, p. 43, text-fig. 8, -3, text-fig.

Globigerinoides conglobatus (Brady)

Globigerina conglobata Brady, 1879, p. 286

Globigerinoides obliquus extremus Bolli and Bermudez (Plate 11, Figures 9, 12)

Globigerinoides obliquus extremus Bolli and Bermudez, 1965, p. 139, pl. 1, fig. 10 through 12.

Globigerinoides obliquus obliquus Bolli (Plate 11, Figures 10, 11)

Globigerinoides obliqua Bolli, 1957a, p. 113, pl. 25, fig. 9 and 10; textfig. 21 , no. 5 .

\section{Globigerinoides primordius Blow and Banner}

(Plate 11, Figures 1, 2)

Globigerinoides quadrilobatus primordius Blow and Banner, 1962, p. 115 , pl. 9, fig. D through F; text-fig. 14, no. iii through viii.

Globigerinoides quadrilobatus (d'Orbigny) s.l.

Globigerina quadrilobata d'Orbigny, 1846, p. 164, pl. 9, fig. 7 through 10.

Globigerinoides trilobus (Reuss) and G. sacculifer (Brady) are included in this category.

Globigerinoides ruber (d'Orbigny)

Globigerina rubra d'Orbigny, 1839a, p. 82, pl. 4, fig. 12 through 14.

Globigerinoides cf. G. ruber (d'Orbigny)

(Plate 11, Figures 1-6)

This taxon occurs in two upper Miocene samples from Hole 410. It is grossly similar in shape to Globigerinoides ruber, except that in umbilical view the ultimate chamber of the final whorl is often asymmetrically placed with respect to the suture between the other two chambers of the final whorl. Supplementary apertures are sometimes present on ultimate and, less frequently, penultimate chambers of the final whorl. If present, there may be one or two per chamber. This form is always encrusted. I have seen this taxon in upper Miocene sediments raised from the Rio Grande Rise in the South Atlantic, and Globigerinoides cf. G. conglobatus of Tjalsma (1971) is probably the same as $G$. cf. $G$. ruber.

\section{Globigerinoides seigliei Bermudez and Bolli} (Plate 3, Figures 10-12)

Globigerinoides ruber seigliei Bermudez and Bolli, 1969, p. 164, pl. 8, fig. 10 through 12 .

\section{Globigerinoides sicanus de Stefani}

$$
\text { (Plate 10, Figure 9) }
$$

Globigerinoides sicana de Stefani, 1952, p. 9 . Note 4 (type figure designated as Globigerinoides conglobata of Cushman and Stainforth, 1945, p. 68 , pl. 13 , fig. 6 ).

Globigerinoides subquadratus Brönnimann (Plate 10, Figures 10-12)

Globigerinoides subquadrata Brönnimann, 1954, in Todd et al., 1954, p. 680, pl. 1 , fig. 5 and 8

\section{Globigerinoides tenellus Parker}

(Plate 1, Figures 1, 2)

Globigerinoides tenellus Parker, 1958, p. 280, pl. 6, fig. 7 through 11.

\section{Globoquadrina altispira (Cushman and Jarvis)}

Globigerina altispira Cushman and Jarvis, 1936, p. 5, pl. 1, fig. 13 and 14.

\section{Globoquadrina baroemoenensis (LeRoy)}

(Plate 18, Figures 8-12)

Globigerina baroemoenensis LeRoy, 1939, p. 263, pl. 6, fig. 1 and 2.

Representatives of Globoquadrina baroemoenensis from Holes 407 and 408 compare well with the phylogenetically advanced form illustrated by Blow (1969, pl. 28, fig. 4), and are compatible with the paratypes housed in the U.S. National Museum. Comparison of Globoquadrina baroemoenensis, as understood here, with the holotype of $G$. larmeui, indicates that Blow (1969) was correct in assuming a close relationship between them. Globoquadrina larmeui appears to have evolved from $G$. baroemoenensis by development of tighter coiling, more angular chambers, and extension of apertural face deeper into the umbilicus prior to formation of an apertural lip or tooth. Globoquadrina obesa Akers represents the end member of this evolutionary trend.

Globoquadrina dehiscens (Chapman, Parr, and Collins)

Globorotalia dehiscens Chapman, Parr, and Collins, 1934, p. 569, pl. 11, fig. 6.

Globoquadrina larmeui Akers (Plate 18, Figures 1-3)

Globoquadrina larmeui Akers, 1955, p. 661, pl. 65, fig. 4.

\section{Globoquadrina praedehiscens Blow and Banner} (Plate 18, Figures 4-7)

Globoquadrina dehiscens praedehiscens Blow and Banner, 1962, p. 116, pl. 15, fig. Q through S.

Globoquadrina venezuelana (Hedberg)

(Plate 14, Figures 4-7)

Globigerina venezuelana Hedberg, 1937, p. 681, pl. 92, fig. 7.

Globorotalia acrostoma Wezel

(Plate 9, Figures 6-9)

Globorotalia acrostoma Wezel, 1966, p. 1298, pl. 101, fig. 1 through 12; text-fig. 1.

In contrast to Globorotalia mayeri, V. acrostoma possesses larger, densely spaced pores, which impart a coarser texture to the test surface. The chambers of Globorotalia acrostoma are less inflated than those of $G$. mayeri; whereas $G$. mayeri has 5 chambers in the ultimate whorl, the ultimate whorl of $G$. acrostoma has 4 or 5 chambers. The two taxa, however, are very similar, and Globorotalia acrostoma could be considered as a subspecies of $G$. mayeri. The two forms have a disjunct distribution pattern in Hole 408, but occur together in the middle Miocene of Hole 407. In this interval of Hole 407, separation of the two forms is difficult. Globorotalia rikuchuensis Takayanagi and Oda is very similar if not identical to G. acrostoma.

\section{Globorotalia anfracta Parker} (Plate 2, Figures 7-9)

Globorotalia anfracta Parker, 1967, p. 175, pl. 28, fig. 3 through 8.

\section{Globorotalia bermudezi Rögl and Bolli}

(Plate 2, Figures 4, 5)

Globorotalia bermudezi Rögl and Bolli, 1973, p. 567, pl. 6, fig. 16 through 20; pl. 16, fig. 1 through 3; text-fig. 6 .

\section{Globorotalia birnageae Blow}

(Plate 10, Figures 4, 5, 7, 8)

Globorotalia birnageae Blow, 1959, p. 210, pl. 17, fig. 108.

\section{Globorotalia blowi (Thompson)}

(Plate 1, Figures 10-12)

Neoacarinina blowi Thompson, 1973, p. 470, pl. 1, fig. 1 through 4 .

The numerous stout, branching tubercles developed on all parts of the test surface are characteristic of this taxon. The multiple "stalagmitic" tubercles are best preserved and seen in and near the umbilicus.

\section{Globorotalia cavernula Bé}

(Plate 3, Figures 8, 9)

Globorotalia cavernula Bé, 1967, p. 128, pl. 10, fig. 1 through 6 . 
Globorotalia conoidea Walters

(Plate 5, Figures 9-12)

Globorotalia miozea conoidea Walters, 1965, p. 124, fig. 8, I through M.

Globorotalia conomiozea Kennett

(Plate 5, Figures 7, 8)

Globorotalia conomiozea Kennett, 1966, p. 235, pl. 1, fig. 8 through 18; pl. 2, fig. 6 through 13; text-fig. 10 .

\section{Globorotalia continuosa Blow \\ (Plate 9, Figures 10-12)}

Globorotalia opima continuosa Blow, 1959, p. 218, pl. 19, fig. 125.

\section{Globorotalia crassaformis (Galloway and Wissler)}

Globigerina crassaformis Galloway and Wissler, 1927, p. 41, pl. 7, fig. 12.

I have made no attempt to recognize the subspecies proposed for this taxon by various authors.

\section{Globorotalia crassula Cushman and Stewart s.l. (Plate 3, Figures 1-7)}

Globorotalia crassula Cushman and Stewart, 1930, in Cushman, Stewart, and Stewart, 1930, p. 77, pl. 7, fig. 1.

I have include specimens referable to Globorotalia crassula viola Blow in this category. Members of Globorotalia crassaformis plexus encountered in Holes 410 through 413 have a tendency to develop a keel, and thus some grade into $G$. crassula viola. Fully keeled specimens are arbitrarily referred to G. crassula s.1., and partially keeled specimens are referred to G. crassaformis

\section{Globorotalia exserta Romeo}

(Plate 7, Figures 1-3)

Globorotalia exserta Romeo, 1969, p. 349, pl. 1, fig. 1 through 7.

Globorotalia hirsuta (d'Orbigny)

Rotalina hirsuta d'Orbigny, 1839b, in Barker-Webb and Berthelot, 1839, p. 131 , pl. 1, fig. 37 through 39

\section{Globorotalia inflata (d'Orbigny)}

(Plate 5, Figures 1-3)

Globigerina inflata d'Orbigny, 1839b, in Barker-Webb and Berthelot, 1839 , p. 134 , pl. 2 , fig. 7 through 9.

\section{Globorotalia kugleri Boll \\ (Plate 10, Figures 1-3)}

Globorotalia kugleri Bolli, 1957a, p. 118, pl. 28, fig. 5 and 6.

\section{Globorotalia lenguaensis Bolli}

(Plate 8, Figures 10-12)

Globorotalia lenguaensis Bolli, 1957a, p. 120, pl. 29, fig. 5.

\section{Globorotalia limbata (Fornasini)}

Rotalia limbata Fornasini, 1902, p. 58, text-fig. 55.

Globorotalia margaritae Bolli and Bermudez (Plate 4, Figures 4-6)

Globorotalia margaritae Bolli and Bermudez, 1965, p. 139, pl. 1, fig. 16 through 18.

\section{Globorotalia mayeri Cushman and Ellisor}

(Plate 9, Figures 1-5)

Globorotalia mayeri Cushman and Ellisor, 1939, p. 11, pl. 2, fig. 4. See Globorotalia acrostoma for comments.

Globorotalia menardii (Parker, Jones, and Brady)

Rotalia menardii Parker, Jones, and Brady, 1865, p. 20, pl. 3, fig. 81.

Globorotalia merotumida Blow and Banner (Plate 8, Figures 1-3)
Globorotalia merotumida Blow and Banner, 1965, in Banner and Blow, 1965 , p. 1352 , fig. 1.

Globorotalia miotumida Jenkins

Globorotalia menardii miotumida Jenkins, 1960, p. 362, pl. 4, fig. 9.

Globorotalia minutissima Bolli

(Plate 4, Figures 7-9)

Globorotalia minutissima Bolli, 1957a, p. 119, pl. 29, fig. 1

Globorotalia miozea Finlay

(Plate 6, Figures 8-12)

Globorotalia miozea Finlay, 1939, p. 326, pl. 29, fig. 159 through 161.

\section{Globorotalia munda Jenkins}

(Plate 20, Figures 8-10)

Globorotalia munda Jenkins, 1966, p. 1121, pl. 13, no. 152 through 166; text-fig. 14 , no. 126 through 133 .

\section{Globorotalia cf. G. munda Jenkins}

(Plate 20, Figures 11-13)

The taxon, very similar to Globorotalia munda, ranges from Oligocene well into the lower Miocene, whereas $G$. munda is thought to be restricted to the Oligocene (Jenkins, 1971). In addition, Globorotalia cf. G. munda tends to have a somewhat better developed lip and is more variable than $G$. munda. Because I have not had the opportunity to examine type material of Globorotalia munda, I prefer for the present to separate the two forms. In contrast to Globorotalia cf. G. munda. Turborotalia clemenciae Bermudez has more separated chambers and a slightly protruding penultimate whorl which results in a convex rather than flat spiral side. The ultimate chamber of the holotype of Turborotalia clemenciae is slightly smaller than the penultimate chamber, but in most Globorotalia cf. G. munda the chambers increase regularly in size.

Globorotalia nana Bolli

Globorotalia opima nana Bolli, 1957a, p. 118, pl. 28, fig. 3 .

Globorotalia opima Bolli

Globorotalia opima opima Bolli, 1957a, p. 117, pl. 28, figs. 1 and 2 .

Globorotalia panda Jenkins

Globorotalia menardii panda Jenkins, 1960, p. 364, pl. 4, fig. 10.

\section{Globorotalia peripheroronda Blow and Banner} (Plate 7, Figures 4-6)

Globorotalia peripheroronda Blow and Banner, 1966, p. 294, pl. 1, fig. 1; pl. 2, fig. 1 through 3 .

\section{Globorotalia plesiotumida Blow and Banner} (Plate 8, Figures 4-6)

Globorotalia tumida plesiotumida Blow and Banner, 1965, in Banner and Blow, 1965, p. 1353, fig. 2.

\section{Globorotalia praehirsuta Blow}

(Plate 4, Figures 1-3)

Globorotalia hirsuta praehirsuta Blow, 1969 , p. 400 , pl. 43 , figs. 3 through 7.

\section{Globorotalia praemenardii Cushman and Stainforth}

Globorotalia praemenardii Cushman and Stainforth, 1945, p. 70, pl. 13, fig. 14.

\section{Globorotalia praescitula Blow}

(Plate 7, Figures 7-9)

Globorotalia scitula praescitula Blow, 1959, p. 221, pl. 19, fig. 128.

\section{Globorotalia pseudokugleri Blow} (Plate 10, Figure 6)

Globorotalia pseudokugleri Blow, 1969, p. 391 (type figure designated as Globorotalia cf. kugleri of Bolli, 1957a, pl. 28, fig. 7). 
Globorotalia puncticulata (Deshayes)

(Plate 5, Figures 4-6)

Globigerina puncticulata Deshayes, 1832, p. 170.

Globorotalia scitula (Brady)

Pulvinulina scitula Brady, 1882, p. 716.

Globorotalia siakensis LeRoy

Globorotalia siakensis LeRoy, 1939, p. 262, pl. 4, fig. 20 through 22.

Globorotalia subscitula Conato

Globorotalia scitula subscitula Conato, 1964, p. 290, pl. 2, fig. 16.

Globorotalia suterae Catalano and Sprovieri

(Plate 6, Figures 1-3)

Globorotalia suterae Catalano and Sprovieri, 1971, p. 241, pl. 1, fig. 1 and 2 ; text-fig. 18.

\section{Globorotalia cf. G. suterae Catalano and Sprovieri}

(Plate 6, Figures 4-7)

This taxon has 4 to 6 inflated chambers in the final whorl and an open, deep umbilicus. The large, comma-shaped, extraumbilical-umbilical aperture is bordered by a weak to well-developed lip. The test wall is smooth with tubercles occasionally present on the umbilical side of the first few chambers of the final whorl. Many specimens closely match the illustrations and description of Globorotalia suterae. There is, however, considerable variation within the population assigned to this category, especially in the middle Miocene of Hole 408, where Globorotalia cf. G. suterae is common to abundant.

\section{Globorotalia tosaensis Takayanagi and Saito}

Globorotalia tosaensis Takayanagi and Saito, 1962, p. 81, pl. 28, fig. 11 and 12 .

\section{Globorotalia truncatulinoides (d'Orbigny)}

Rotalina truncatulinoides d'Orbigny, 1839b, in Barker-Webb and Berthelot, p. 132, pl. 2, fig. 25 through 27.

\section{Globorotalia tumida (Brady) \\ (Plate 8, Figures 7-9)}

Pulvinulina menardii var. tumida Brady, 1877, p. 535.

The figured specimen is considered to be a phylogenetically primitive representative of Globorotalia tumida.

\section{Globorotalia ventriosa Ogniben}

(Plate 4, Figures 10-12)

Globorotalia scitula ventriosa Ogniben, 1958, p. 246, pl. 15, fig. 4 and 5.

Globorotalia zealandica Hornibrook

(Plate 7, Figures 10-12)

Globorotalia zealandica Hornibrook, 1958, p. 667, fig. 18, 19, and 30 .

Globorotaloides hexagona (Natland)

Globigerina hexagona Natland, 1938, p. 149, pl. 7, fig. 1.

Globorotaloides suteri Bolli

Globorotaloides suteri Bolli, 1957a, p. 117, pl. 27, fig. 9-13.

\section{Hastigerina pelagica (d'Orbigny)}

(Plate 1, Figure 6)

Nonionina pelagica d'Orbigny, 1839a, p. 27, pl. 3, fig. 13 and 14

\section{Hastigerinopsis riedeli (Rögl and Bolli)} (Plate 19, Figures 1-4)

Hastigerinella riedeli Rögl and Bolli, 1973, p. 567, text-fig. 5; pl. 4, fig. 1 through 5 ; pl. 14, fig. 1 through 3.

This distinctive, albeit minute, foraminifer was detected in Quaternary sediments in all areas sampled by DSDP Leg 49 . Originally described from the Caribbean occurrence, this taxon appears to be restricted to the Quaternary.

In view of its wide geographic distribution, Hastigerinopsis riedeli may prove useful in identifying Quaternary planktonic foraminiferal assemblages, in the absence of Globorotalia truncatulinoides. Assignment of this species to Hastigerinopsis follows Saito et al. (1976).

\section{Neogloboquadrina acostaensis (Blow)}

(Plate 17, Figures 1-3)

Globorotalia acostaensis Blow, 1959, p. 208, pl. 17, fig. 106 and 107

\section{Neogloboquadrina atlantica (Berggren)}

(Plate 16, Figures 1-12)

Globigerina atlantica Berggren, 1972, p. 972, pl. 1, fig. 1 through 7; pl.

2 , fig. 5 through 8.

As noted earlier in this paper, abundant, sinistrally coiling Neogloboquadrina atlantica appears to be an excellent Pliocene indicator in the sub-boreal North Atlantic. For additional discussion and illustrations of this taxon, see Poore and Berggren (1975a, b). A possible ancestor of Neogloboquadrina atlantica occurs in the middle Miocene of Holes 407 and 408 , and is recorded on Tables 2 and 3 as $N$. atlantica (primitive form). This primitive form has 4 globular to sub-globular chambers in the final whorl. The umbilical to extraumbilical-umbilical aperture is lipped and has a tendency to be "comma-shaped," which suggests a relationship with Globorotalia continuosa.

The test-surface ultrastructure of Neogloboquadrina atlantica (primitive form) is the same as that observed on other Neogloboquadrina, but the heavy secondary encrustation observed on many individuals in populations of typical $N$. atlantica was not found on the primitive form.

\section{Neogloboquadrina "du/pac"}

(Plate 17, Figures 9, 11, 12)

This category is used for Quaternary specimens considered to be intergrades between Neogloboquadrina dutertre $i$ and $N$. pachyderma. The term "du/pac" is arbitrarily restricted to dextrally coiling forms with 4 to 5 chambers in the final whorl.

\section{Neogloboquadrina dutertrei (d'Orbigny)}

Globigerina dutertrei d'Orbigny, 1830, p. 84, pl. 4, fig. 19 through 21.

\section{Neogloboquadrina humerosa (Takayanagi and Saito)} (Plate 17, Figures 4-6)

Globorotalia humerosa Takayanagi and Saito, 1962, p. 78, pl. 78, fig. 1 and 2.

Neogloboquadrina pachyderma (Ehrenberg) (Plate 17, Figures 7, 8, 10)

Aristerospira pachyderma Ehrenberg, 1861, p. 303.

In my opinion, typical or modern-looking Neogloboquadrina pachyderma does not occur until the upper Pliocene. Upper Miocene and lower Pliocene planktonic foraminiferal assemblages, however, do contain a form very close to Neogloboquadrina pachyderma s.s. The older forms, or $N$. pachyderma s.1., do not develop the heavy glassy to sugary textured secondary encrustation common in younger representatives of $N$. pachyderma. Moreover, the equatorial outline of $N$. pachyderma s.1. is circular to subquadrate, whereas the equatorial outline of $N$. pachyderma s.s. is often oval.

\section{Orbulina spp.}

This category includes Orbulina universa d'Orbigny and $O$. suturalis Brönnimann.

\section{Praeorbulina sp.}

Two possible occurrences of Praeorbulina were noted in Hole 408. The specimens were too few and poorly preserved for confident identification.

\section{Pulleniatina finglis Banner and Blow}

Pulleniatina obliquiloculata finalis Banner and Blow, 1967, p. 140, pl. 2 , fig. 4 through $10 ;$ pl. 3 , fig. 5 ; pl. 4 , fig. 10 . 
Pulleniatina obliquiloculata (Parker and Jones)

Pullenia sphaeroides var. obliquiloculata Parker and Jones, 1865, p. 365 , 368 , pl. 19, fig. 4.

Sphaeroidinella dehiscens (Parker and Jones)

Sphaeroidina bulloides var. dehiscens Parker and Jones, 1865, p. 369, pl. 19 , fig. 5

\section{Sphaeroidinellopsis seminulina (Schwager)}

(Plate 14, Figures 1-3)

Globigerina seminulina Schwager, 1866, p. 267, pl. 7, fig. 112

Specimens figured do not have the thick cortex usually found on Sphaeroidinellopsis seminulina. Some workers would assign these specimens to Sphaeroidinellopsis disjuncta (Finlay).

\section{Sphaeroidinellopsis subdehiscens (Blow) \\ Sphaeroidinella dehiscens subdehiscens Blow, 1959, p. 195, pl. 12, fig. 71 and 72}

\section{Turborotalita cristata (Heron-Allen and Earland)} (Plate 2, Figures 10-12)

Globigerina cristata Heron-Allen and Earland, 1929, p. 331, pl. 4, fig. 37 through 39, ?33-36.

The minute specimens referred to this taxon are interpreted as juveniles that have not yet developed a modified bulla-like final chamber covering the umbilicus. Parker (1962) includes Turborotalita cristata with $T$. humilis, and some $T$. humilis do show an indication of separated, radially elongated chambers (note penultimate whorl of Figure 5, Plate 1). Turborotalita humilis, however, is thought to be a non-spinose form, and $T$ cristata, as identified here, has long, delicate spines with a circular crosssection concentrated on the distal ends of chambers.

\section{Turborotalita humilis (Brady)}

(Plate 1, Figures 4, 5)

Truncatulina humilis Brady, 1884, p. 665, pl. 94, fig. 7.

Turborotalita quinqueloba (Natland)

(Plate 15, Figures 9, 10)

Globigerina quinqueloba Natland, 1938, p. 149, pl. 6, fig. 7.

\section{ACKNOWLEDGMENTS}

I thank W.V. Sliter and J.A. Barron of the U.S. Geological Survey for helpful comments. Micrographs were taken with a Cambridge SEM operated by R.L. Oscarson. I especially thank S.E. Murphy for technical assistance throughout this study and I appreciate the opportunity afforded me by the Deep Sea Drilling Project to participate as a member of the shipboard scientific crew of Leg 49.

\section{REFERENCES}

Akers, W.H., 1955. Some planktonic Foraminifera of the American Gulf Coast and suggested correlations with the Caribbean Tertiary, Journal of Paleontology, v. 29, p. 647-664.

Banner, F.T. and Blow, W.H., 1960a. Some primary types of species belonging to the superfamily Globigerinaceae, Cushman Foundation for Foraminiferal Research, Contributions, v. 11, p. 1-41.

, 1960b. The taxonomy, morphology and affinities of the genera included in the subfamily Hastigerininae, $\mathrm{Mi}$ cropaleontology, v. 6, p. 19-31.

1965. Two new taxa of the Globorotaliinae (Globigerinacea, Foraminifera) assisting determination of the late Miocene/middle Miocene Boundary, Nature, v. 207, p. 1351-1354.

1967. The origin, evolution and taxonomy of the foraminiferal genus Pulleniatina Cushman, 1927, Micropaleontology, v. 13, p. 133-162.
Bé, A.W.H., 1967. Globorotalia cavernula, a new species of planktonic Foraminifera from the subantarctic Pacific Ocean, Cushman Foundation for Foraminiferal Research, Contributions, v. 18 , p. 128-132.

Beckmann, J.P., 1957. Chiloguembelina Loeblich and Tappan and related Foraminifera from the lower Tertiary of Trinidad, B.W.I., United States National Museum Bulletin 215, p. 83-95.

Berggren, W.A., 1972. Cenozoic Biostratigraphy and paleobiogeography of the North Atlantic. In Laughton, A.S., Berggren, W.A., et al., Initial Reports of the Deep Sea Drilling Project, v. 12: Washington (U.S. Government Printing Office), p. 965-999.

Berggren, W.A. and Amdurer, M., 1973. Late Paleogene (Oligocene) and Neogene planktonic foraminiferal biostratigraphy of the Atlantic Ocean (Lat. $30^{\circ} \mathrm{N}$. to Lat. $30^{\circ} \mathrm{S}$.), $R e$ vista Italiana Paleontologia e Stratigrafia, v. 79, p. 337-391.

Berggren, W.A. and Van Couvering, J.A., 1974. The later Neogene biostratigraphy, geochronology and paleoclimatology of the last 15 million years in marine and continental sequences, Palaeogeography, Palaeoclimatology, Palaeoecology, v. 16, p. 1-216.

Berggren, W.A., Benson, R.H., Haq, B.U., Riedel, W.R., Sanfilippo, A., Schrader, H.-J., and Tjalsma, R.C., 1976. The El Cuervo section (Andalusia, Spain): Micropaleontologic anatomy of any early late Miocene lower bathyal deposit, Marine Micropaleontology, v. 1, p. 195-247.

Bermudez, P.J., 1961. Contribucion al estudio de las Globigerinidea de la region Caribe-Antillana (PaleocenoReciente), Boletin Geologia (Venezuela), Special Publication 3 (Cong. Geol. Venezolano, 3rd, Caracas 1959, Mem. 3), p. 1119-1393.

Bermudez, P.J., and Bolli, H.M., 1969. Consideraciones sobre los sedimentos del Mioceno Medio al Reciente de las costas central y oriental de Venezuela, Boletin Geologia (Venezuela), v. 10 , p. $137-223$.

Bizon, G. and Bizon, J.-J., 1972. Atlas des Principaux Foraminiferes du Bassin Mediterraneen Oligocene a Quaternaire: Paris (Editions Technip).

Blow, W.H., 1959. Age, correlation, and biostratigraphy of the upper Tocuyo (San Lorenzo) and Pozon Formations, eastern Falcon, Venezuela, Bulletins American Paleontology, v. 39, p. 1-251.

, 1969. Late middle Eocene to Recent planktonic foraminiferal biostratigraphy. In Bronnimann, P. and Renz, H.H. (Eds.), Proceedings of First Planktonic Conference: Leiden (E.J. Brill), p. 199-422.

Blow, W.H. and Banner, F.T., 1962. The mid-Tertiary (upper Eocene-Aquitanian) Globigerinaceae. In Eames, F.E., Banner, F.T., Blow, W.H., and Clarke, W.J. (Eds.), Fundamentals of Mid-Tertiary Stratigraphical Correlation: Cambridge (Cambridge University Press), p. 61-151.

, 1966. The morphology, taxonomy and biostratigraphy of Globorotalia barisanensis LeRoy, Globorotalia fohsi Cushman and Ellisor, and related taxa, Micropaleontology, v. 12 , p. $286-302$.

Bolli, H.M., 1954. Note on Globigerina concinna Reuss 1850, Cushman Foundation for Foraminiferal Research, Contributions, v. 5, pt. 1, p. 1-3.

, 1957a. Planktonic Foraminifera from the Oligocene-Miocene Cipero and Lengua Formations of Trinidad, B.W.I., United States National Museum Bulletin 215, p. 97-124.

, 1957b. Planktonic Foraminifera from the Eocene Navet and San Fernando Formations of Trinidad, B.W.I., United States National Museum Bulletin 215, p. 155-172. 
Bolli, H.M. and Bermudez, P.J., 1965. Zonation based on planktonic foraminifera of middle Miocene to Pliocene warm-water sediments, Associacion Venezolana Geologia, Mineria y Petroleo Boletin Informativo, v. 8, p. 119-149.

Bolli, H.M., Loeblich, A.R., and Tappan, Helen, 1957. Planktonic Foraminiferal Families Hantkeninidae, Orbulinidae, Globorotaliidae and Globotruncanidae, United States National Museum Bulletin 215, p. 3-50.

Borsetti, A.M., 1959. Tre Nuovi Foraminiferi Planctonici dell'Oligocene Piacentino, Giornale di Geologia, v. 27, p. 205-212.

Brady, H.B., 1877. Supplementary note on the Foraminifera of the Chalk(?) of the New Britain Group, Geological Magazine New Series, Decade II, v. 4, p. 534-536. , 1879. Notes on some of the reticularian Rhizopoda of the Challenger Expedition, Quarterly Journal of Microscopical Science, London, v. 19, p. 20-26, 261-299.

1882. Report on the Foraminifera. In Tizard and Murray, Exploration of the Faröe Channel, during the summer of 1880 , in H.M.S. "Knight Errant," with subsidiary reports, Proceedings of the Royal Society of Edinburgh, v. 11 (1880$1882)$, no. 111 , p. $708-717$.

, 1884. Report on the Foraminifera dredged by H.M.S. Challenger during the years 1873-1876, Report on the Scientific Results of the H.M.S. Challenger during the years 187376, London, Zoology, v. 9, pt. 22, 814 p.

Bukry, D., 1971. Coccolith stratigraphy Leg 7, Deep Sea Drilling Project. In Winterer, E.L., Riedel, W.R., et al., Initial Reports of the Deep Sea Drilling Project, v. 7: Washington (U.S. Government Printing Office), p. 1513-1528.

, 1972. Coccolith stratigraphy Leg 9, Deep Sea Drilling Project. In Hays, J.D., et al., Initial Reports of the Deep Sea Drilling Project, v. 9: Washington (U.S. Government Printing Office), p. 817-832.

, 1973a. Low-latitude coccolith biostratigraphic zonation. In Edgar, N.T., Saunders, J.B., et al., Initial Reports of the Deep Sea Drilling Project, v. 15: Washington (U.S. Government Printing Office), p. 685-703.

1973b. Coccolith and silicoflagellate stratigraphy, Tasman Sea and southwestern Pacific Ocean, Deep Sea Drilling Project Leg 21. In Burns, R.E., Andrews, J.E., et al., Initial Reports of the Deep Sea Drilling Project, v. 21: Washington (U.S. Government Printing Office), p. 885-893.

Catalano, R. and Sprovieri, R., 1971. Biostratigrafia di alcune serie Sahelieane (Messiniano Inferiore) in Sicilia. In Farinacci, A. (Ed.), Proceedings of Second Planktonic Conference. Roma (Tecnoscienza), p. 211-249.

Chapman, F., Parr, W.J., and Collins, A.C., 1934. Tertiary Foraminifera of Victoria, Australia - The Balcombian deposits of Port Phillip, pt. 3, Linnean Society London Journal, Zoology, v. 38 , p. 553-577.

Cita, M.B., 1973. Pliocene biostratigraphy and chronostratigraphy. In Ryan, W.B.F., Hsï, K.J., et al., Initial Reports of the Deep Sea Drilling Project, v. 13: Washington (U.S. Government Printing Office), p. 1343-1379.

Conato, V., 1964. Alcuni foraminiferi nuovi nel Pliocene nordappenninico, Geologica Romana, v. 3, p. 279-302.

Crescenti, U., 1966. Sulla biostratigrafia del Miocene affiorante al confine marchigiano-abruzzese, Geologica Romana, v. 5, p. 1-54.

Cushman, J.A., 1918. Some Pliocene and Miocene Foraminifera of the coastal plain of the United States, United States Geological Survey Bulletin 676, p. 1-100.

Cushman, J.A. and Ellisor, A.C., 1939. New species of Foraminifera from the Oligocene and Miocene, Cushman Laboratory for Foraminiferal Research, Contributions, v. 13, p. 1-29.
Cushman, J.A. and Ellisor, A.C., 1939. New species of Foraminifera from the Oligocene and Miocene, Cushman Laboratory for Foraminiferal Research, Contributions, v. 15, p. 1-14.

Cushman, J.A. and Jarvis, P.W., 1936. Three new Foraminifera from the Miocene, Bowden marl, of Jamaica, Cushman Laboratory for Foraminiferal Research, Contributions, v. 12, p. 3-5.

Cushman, J.A. and Ponton, G.M., 1932. The Foraminifera of the Upper, Middle and part of the Lower Miocene of Florida, Florida Geological Survey, Bulletin, no. 9, p. 7-147.

Cushman, J.A. and Stainforth, R.M., 1945. The Foraminifera of the Cipero Marl Formation of Trinidad, British West Indies, Cushman Laboratory for Foraminiferal Research, Special Publication 14, p. 1-75.

Cushman, J.A., Stewart, R.E., and Stewart, K.C., 1930. Tertiary Foraminifera from Humboldt County, California, San Diego Society of Natural History, Transactions, v. 6, p. 43-90.

Deshayes, G.P., 1832. Encyclopedie methodique; Histoire naturelle des vers. Paris (Mme. v. Agasse), v. 2, pt. 2, 594 p.; v. 3 , p. 595-1152.

D'Onofrio, S., Giannelli, L., Iaccarino, S., Morlotti, E., Romeo, M., Salvatorini, G., Sampo, M., and Sprovieri, R., 1975. Planktonic Foraminifera of the upper Miocene from some Italian sections and the problem of the lower boundary of the Messinian, Estratto dal Bollettino Societa Paleontologica Italiana, v. 14, p. 177-196.

De Stefani, T., 1952. Su alcune manifestazioni di idrocarburi in provincia de Palermo e descrizione di foraminiferi nuovi, Plinia (Palermo, Italy), v. 3, p. 1-12.

Egger, J.G., 1893. Foraminiferen aus Meeresgrundproben, gelothet von 1874 bis 1876 von S.M. Sch. Gazelle, Abhandlungen der Mathematisch-Physikalischen Klasse der Königlich Bayerischen Akademie der Wissenschaften, v. 18, p. 193-458 (1-266).

Ehrenberg, C.G., 1861. Elemente des tiefen Meeresgrundes im Mexikanischen Golfstrome bei Florida; Uber die TiefgrundeVerhältnisse des Oceans am eingange der Davisstrasse und bei Island, Monatsberichte der Königliche Preussische Akademie Wissenschaften zu Berlin, p. 222-240, 275-315.

Finlay, H.J., 1939. New Zealand Foraminifera: key species in stratigraphy, no. 3, Royal Society of New Zealand Transactions, v. 69 , no. 3 , p. $309-329$.

Fornasini, C., 1902. Sinossi metodica dei foraminiferi sin qui rinvenuti nella sabbia del Lido di Rimini, Memorie della Royal Accademie della Scienze dell'Istituto di Bologna, Sezione delle Scienze Naturali, Bologna, ser. 5, v. 10 (1902-1904), p. 1-68 (3-70).

Galloway, J.J. and Wissler, S.G., 1927. Pleistocene Foraminifera from the Lomita quarry, Palos Verdes Hills, California, Journal of Paleontology, v. 1, p. 35-87.

Hays, J.D., Saito, T., Opdyke, N.D., and Burckle, L.H., 1969. Pliocene-Pleistocene sediments of the equatorial Pacific: Their paleoclimatic, biostratigraphic and climatic record, Geological Society of America Bulletin, v. 80, p. 1481-1514.

Hedberg, H.D., 1937. Foraminifera of the middle Tertiary Carapita Formation of northeastern Venezuela, Journal of Paleontology, v. 11, p. 661-697.

Heron-Allen, E. and Earland, A., 1929. Some new Foraminifera from the South Atlantic, Royal Microscopical Society of London Journal, ser. 3, v. 49, pt. I, p. 102-108, pt. II, p. 324-334.

Hofker, J., 1956. Foraminifera Dentata: Foraminifera of Santa Cruz and Thatch-Island Virginia-Archipelago West-Indies, Universitets Zoologiske Museum, København, Spolia (Skrifter), v. 15, p. 234.

Hornibrook, N. de B., 1958. New Zealand Foraminifera: key species in stratigraphy - No. 6, New Zealand Journal of Geology and Geophysics, v. 1, p. 653-676. 
, 1965. Globigerina angiporoides $\mathrm{n}$. sp. from the upper Eocene and lower Oligocene of New Zealand and the status of Globigerina angipora Stache, 1865, New Zealand Journal of Geology and Geophysics, v. 8, no. 2, p. 834-838.

Hornibrook, N. de B. and Edwards, A.R., 1971. Integrated planktonic foraminiferal and calcareous nannoplankton datum levels in the New Zealand Cenozoic. In Farinacci, A. (Ed.), Proceedings of Second Planktonic Conference: Roma (Tecnoscienza), p. 649-657

Howe, H.V. and Wallace, W.E., 1932. Foraminifera of the Jackson Eocene at Danville Landing on the Ouachita, Catahoula Parish, Louisiana, Louisiana Department of Conservation, Geological Bulletin, p. 1-188.

Jenkins, D.G., 1960. Planktonic Foraminifera from the Lakes Entrance oil shaft, Victoria, Australia, Micropaleontology, v.6, p. 345-371.

, 1964. A new planktonic foraminiferal subspecies from the Australasian Lower Miocene, Micropaleontology, v. 10, p. 72 .

, 1966. Planktonic foraminiferal zones and new taxa from the Danian to Lower Miocene of New Zealand, New Zealand Journal of Geology and Geophysics, v. 8, p. 10881126.

, 1971. New Zealand Cenozoic Planktonic Foraminifera, New Zealand Geological Survey Paleontological Bulletin 42, p. 1-278.

Jenkins, D.G. and Orr, W.N., 1972. Planktonic foraminiferal biostratigraphy of the eastern equatorial Pacific - DSDP Leg 9. In Hays, J.D., et al., Initial Reports of the Deep Sea Drilling Project, v. 9: Washington (U.S. Government Printing Office), p. 1059-1193.

Kennett, J.P., 1966. The Globorotalia crassaformis bioseries in north Westland and Marlborough, New Zealand, Micropaleontology, v. 12, p. 235-245.

Kennett, J.P., 1973. Middle and late Cenozoic planktonic foraminiferal biostratigraphy of the southwest Pacific — DSDP Leg 21. In Burns, R.E., Andrews, J.E., et al., Initial Reports of the Deep Sea Drilling Project, v. 21: Washington (U.S. Government Printing Office), p. 575-639.

Koch, R.E., 1926. Mitteltertiare Foraminiferen aus Bulongan, Ost-Borneo, Eclogae Geologicae Helvetiae, v. 19, p. 722-751.

LeRoy, L.W., 1939. Some small Foraminifera, Ostracoda, and otoliths from the Neogene ("Miocene") of the Tokan-Tapanoeli area, central Sumatra. Natuurkundig Tijdschrift NederlandschIndië, v. 99, no. 6, p. 215-296.

1944. Miocene Foraminifera from Sumatra and Java, Netherlands East Indies - Part 1. Miocene Foraminifera of Central Sumatra, Netherlands East Indies, Colorado School of Mines Quarterly, v. 39, p. 9-69.

Martini, E., 1971. Standard Tertiary and Quaternary calcareous nannoplankton zonation. In Farinacci, A. (Ed.), Proceedings of Second Planktonic Conference: Roma (Tecnoscienza), p. $739-785$.

Natland, M.L., 1938. New species of Foraminifera from off the west coast of North America and from the later Tertiary of the Los Angeles Basin, University of California, Scripps Institution of Oceanography Bulletin, Technical Series, v. 4, p. 137-164.

Ogniben, L., 1958. Stratigrafie e microfaune del Terzierio della zona di Caiazzo (Caserta): 6-Descrizione paleontologiche, Rivista Italiana Paleontologia e Stratigrafia, v. 65, p. 199-286.

Orbigny, A. d', 1826. Tableau méthodique de la classe des Céphalopodes, Annales des Sciences Naturelles de Paris, ser. 1, v. 7, p. 95-169, 245-314.

, 1839a. Foraminifères. In Sagra, Ramón de la, Histoire physique, politique et naturelle de l'île de Cuba: Paris (A. Bertrand), 224 p. 1839b. Foraminiferes des l'îles Canaries. In BarkerWebb and Berthelot, Histoire Naturelle des l'îles Canaries: Paris (Bethune), v. 2, pt. 2, Zool., p. 120-146.

1846. Foraminiferes fossiles du bassin tertiaire de Vienne (Autriche): Paris (Gide et Companie), $303 \mathrm{p}$.

Orr, W.N. and Zaitzeff, J.B., 1971. A new planktonic foraminiferal species from the California Pliocene, Journal of Foraminiferal Research, v. 1, p. 17-19.

Palmer, D.K., 1934. The foraminiferal genus Gümbelina in the Tertiary of Cuba, Memorias de la Sociedad cubana de historia natural, v. 8, p. 73-76.

Parker, F.L., 1958. Eastern Mediterranean Foraminifera, Swedish Deep-Sea Expedition Reports, v. 8, p. 219-283.

, 1962. Planktonic foraminiferal species in Pacific sediments, Micropaleontology, v. 8, p. 219-254.

, 1967. Late Tertiary biostratigraphy (Planktonic Foraminifera) of tropical Indo-Pacific deep-sea cores, Bulletins of American Paleontology, v. 52, p. 115-208.

Parker, W.K. and Jones, T.R., 1865. On some Foraminifera from the North Atlantic and Arctic oceans, including Davis Straits and Baffin's Bay, Philosophical Transactions of the Royal Society of London, v. 155, p. 325-441.

Parker, W.K., Jones, T.R., and Brady, H.B., 1865. On the nomenclature of the Foraminifera; Pt. XII (misprinted as Pt. X continued) - The species enumerated by d'Orbigny in the “Annales des Sciences Naturelles,"'v. 7, 1826, The Annals and Magazine of Natural History, London, ser. 3, v. 16, p. 15-41.

Poore, R.Z. and Berggren, W.A., 1974. Pliocene biostratigraphy of the Labrador Sea: Calcareous plankton, Journal of Foraminiferal Research, v. 4, p. 91-108.

, 1975a. The morphology and classification of Neogloboquadrina atlantica (Berggren), Journal of Foraminiferal Research, v. 5, p. 77-84. , 1975b. Late Cenozoic planktonic foraminiferal biostratigraphy and paleoclimatology of Hatton-Rockall Basin: DSDP Site 116, Journal of Foraminiferal Research, v. 5, p. 270-293.

Rögl, F. and Bolli, H.M., 1973. Holocene to Pleistocene Planktonic Foraminifera of Leg 15, Site 147 (Cariaco Basin [Trench], Caribbean Sea) and their climatic interpretation. In Edgar, N.T., Saunders, J.B., et al., Initial Reports of the Deep Sea Drilling Project, v. 15: Washington (U.S. Government Printing Office), p. 553-615.

Romeo, M., 1969. Globorotalia (T.) exserta nuova specie della sommita del Tortoniano di M. Giammoia presso Gela (Caltanissetta), Atti dell' Accademia gioenia di Scienze naturali Catania, v. 1, suppl. Sc. Geol., p. 349-352.

Ryan, W.B.F., Cita, M.B., Rawson, M.D., Burckle, L.H., and Saito, T., 1975. A paleomagnetic assignment of Neogene Stage boundaries and the development of isochronous datum planes between the Mediterranean, the Pacific and Indian Oceans in order to investigate the response of the world ocean to the Mediterranean "salinity crisis,', Rivista Italiana Paleontologia e Stratigraphia, v. 80, p. 631-688 (1974).

Saito, T., Thompson, P.R., and Breger, D., 1976. Skeletal ultramicrostructure of some elongate-chambered planktonic foraminifera and related species. In Takayanagi, Y. and Saito, T. (Eds.), Progress in Micropaleontology: New York (Micropaleontology Press), p. 278-304.

Salvatorini, G., 1966. Alcune nuove specie di foraminiferi del Miocene superiore della Toscana Marittima, Atti della Societa Toscana di Scienze Naturali, Pisa, Italy, Memorie, ser. A, v. 73 , p. 3-13.

Schwager, C., 1866. Fossile Foraminiferen von Kar Nikobar. Novara Exped. 1857-1859, Wien, Geol. Theil, v. 2, p. 187-268. 
Stainforth, R.M., Lamb, J.L., Luterbacher, H., Beard, J.H., and Jeffords, R.M., 1975. Cenozoic planktonic foraminiferal zonation and characteristics of index forms. The University of Kansas Paleontological Contributions, Article 62, 425 p.

Takayanagi, Y. and Saito, T., 1962. Planktonic Foraminifera from the Nobori Formation, Shikoku, Japan, Tohoku University Science Reports, Second Series (Geology), Special Volume No. 5, p. 67-105.

Thompson, P.R., 1973. Two new late Pleistocene planktonic Foraminifera from a core in the southwest Indian Ocean, Micropaleontology, v. 19 , p. 469-474.

Tjalsma, R.C., 1971. Stratigraphy and Foraminifera of the Neogene of the eastern Guadalquivir Basin (Southern Spain), Utrecht Micropaleontological Bulletins, v. 4, p. 1-161.
Todd, R., 1957. Smaller Foraminifera, United States Geological Survey Professional Paper 280-H, p. 265-320.

Todd, R., Cloud, P.E., Jr., Low, D., and Schmidt, R.G., 1954. Probable occurrence of Oligocene on Saipan, American Journal of Science, v. 252, p. 673-682.

Van Couvering, J.A., Berggren, W.A., Drake, R.E., Aguirre, E., and Curtis, G.H., 1976. The Terminal Miocene event, Marine Micropaleontology, v. 1, p. 263-286.

Walters, R., 1965. The Globorotalia zealandica and G. miozea lineages, New Zealand Journal of Geology and Geophysics, v. 8 , p. $109-127$

Wezel, F.C., 1966. Globorotalia acrostoma, nuova specie dell'Oligomiocene italiano, Rivista Italiana Paleontologia $e$ Stratigrafia, v. 72, p. 1298-1306. 



\section{PLATE 1}

Figures 1, 2 Globigerinoides tenellus Parker. Both from Hole 412, Sample 1, CC.

1. Umbilical view, scale bar $=30 \mu \mathrm{m}$. USNM 249141.

2. Spiral view, scale bar $=30 \mu \mathrm{m}$. USNM 249142 .

Figure 3 Globigerinella aequilateralis (Brady). Equatorial view, from Hole 412, Sample 1-1, 70-72 cm. Scale bar $=100 \mu \mathrm{m}$. USNM 249143.

Figures 4, 5 Turborotalita humilis (Brady). Both from Hole 412, Sample 1, CC.

4. Umbilical view, scale bar $=30 \mu \mathrm{m}$. USNM 249144.

5. Spiral view, scale bar $=30 \mu \mathrm{m}$. USNM 249145 .

Figure 6 Hastigerina pelagica (d'Orbigny). Equatorial view, from Hole 412, Sample 1-1, 70-72 cm. Scale bar $=$ $100 \mu \mathrm{m}$. USNM 249146.

Figures 7-9 Globigerinoides bulloideus Crescenti. Both from Hole 410, Sample 29, CC.

7. Spiral view, scale bar $=100 \mu \mathrm{m}$. USNM 249147.

8. Umbilical view, scale bar $=100 \mu \mathrm{m}$. USNM 2491477.

9. Detail of Fig. 8. Expanded contrast view of aperture. Note inner rim of supplementary aperture, scale bar $=30 \mu \mathrm{m}$.

Figures 10-12 Globorotalia blowi (Thompson). Hole 412, Sample 2, CC.

10. Umbilical view, scale bar $=100 \mu \mathrm{m}$. USNM 249149.

11. Detail of ultimate chamber near umbilicus. Scale bar $=10 \mu \mathrm{m}$.

12. Spiral view of Figure 10, scale bar $=100 \mu \mathrm{m}$. 
PLATE 1

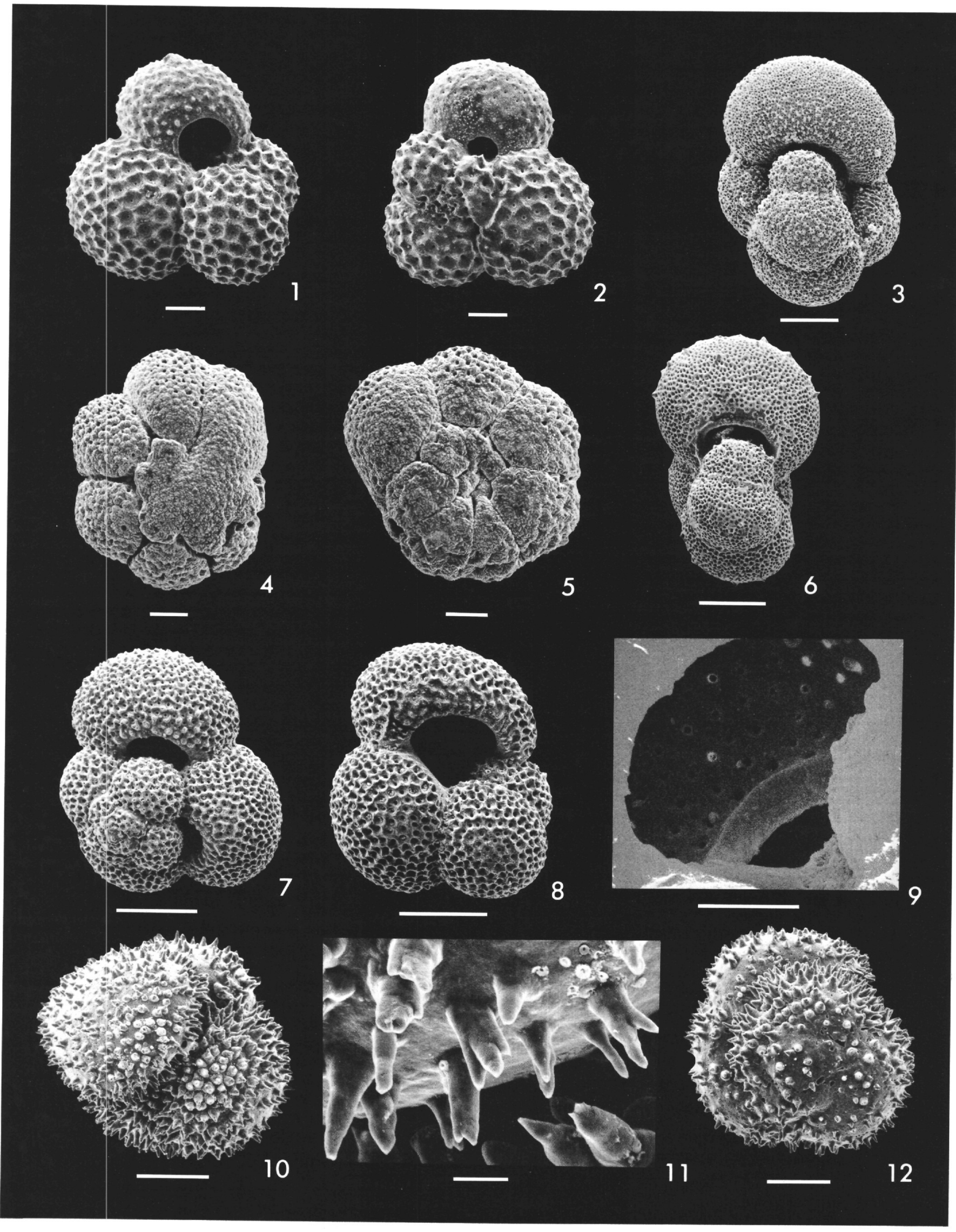




\section{PLATE 2}

Figures 1, 2 Globigerina rubescens Hofker. Both from Hole 412, Sample 1-1, 70-72 cm.

1. Umbilical view, scale bar $=30 \mu \mathrm{m}$. USNM 249150.

2. Spiral view, scale bar $=30 \mu \mathrm{m}$. USNM 249151 .

Figures 3, 6 Globigerina digitata Brady. Both from Hole 412, Sample 1-1, 70-72 cm.

3. Umbilical view, scale bar $=100 \mu \mathrm{m}$. USNM 249152.

6. Spiral view, scale bar $=100 \mu \mathrm{m}$. USNM 249153.

Figures 4, 5 Globorotalia bermudezi Rögl and Bolli. Hole 412, Sample 1, CC.

4. Spiral view, scale bar $=30 \mu \mathrm{m}$. USNM 249154.

5. Umbilical view of Fig. 4 , scale bar $=30 \mu \mathrm{m}$.

Figures 7-9 Globorotalia anfracta Parker. All from Hole 412, Sample 1-1, 70-72 cm.

7. Umbilical view, scale bar $=30 \mu \mathrm{m}$. USNM 249155.

8. Side view, scale bar $=63 . \mu \mathrm{m}$. USNM 249156.

9. Spiral view, scale bar $=30 \mu \mathrm{m}$. USNM 249157.

Figures 10-12 Turborotalita cristata (Heron-Allen and Earland). All from Hole 412, Sample 1-1, 70-72 cm.

10. Umbilical view, scale bar $=30 \mu \mathrm{m}$. USNM 249158.

11. Side view, scale bar $=30 \mu \mathrm{m}$. USNM 249159.

12. Spiral view, scale bar $=30 \mu \mathrm{m}$. Note spines concentrated at distal ends of chambers. USNM 249160. 
PLATE 2

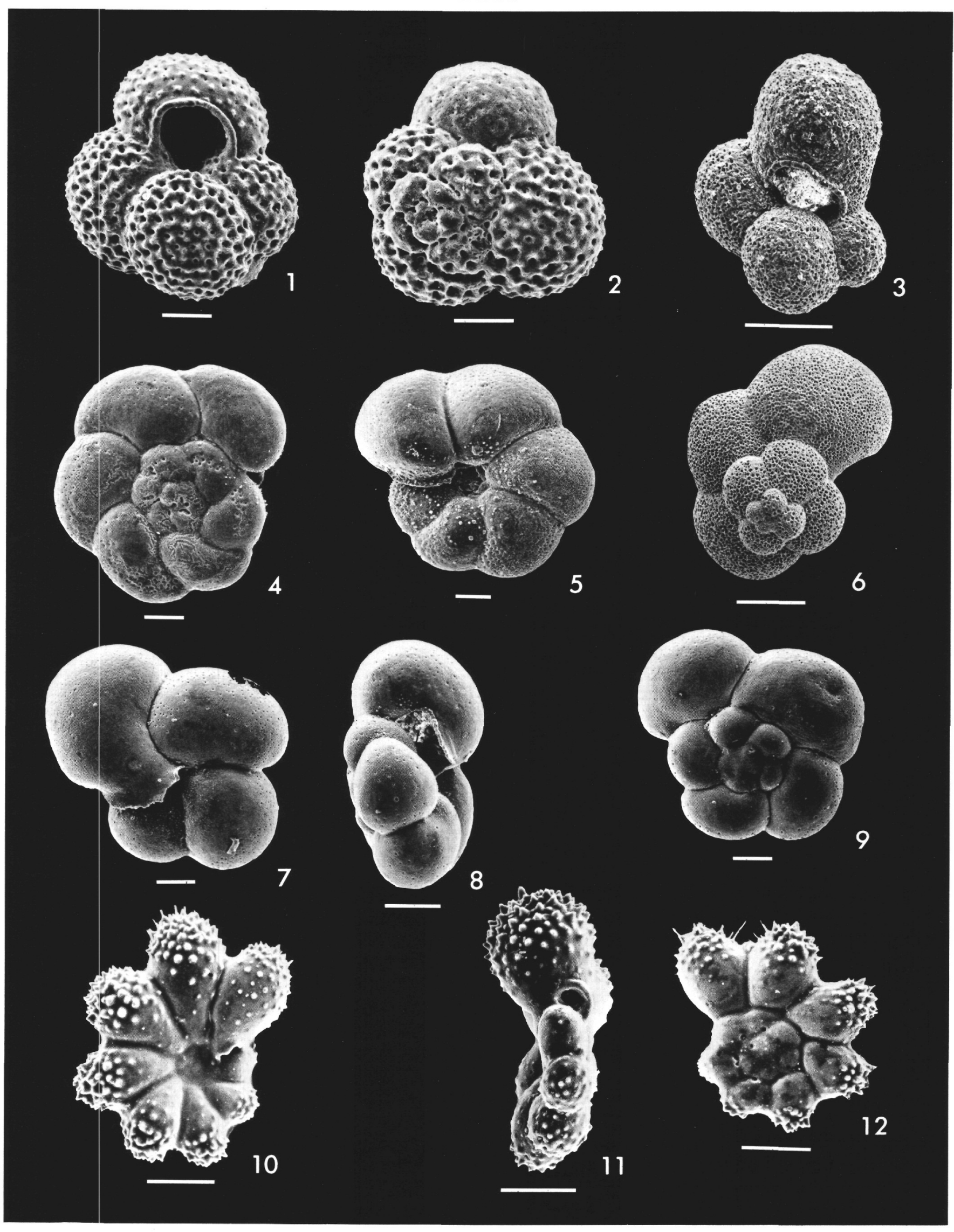




\section{PLATE 3}

Figures 1-7 Globorotalia crassula Cushman and Stewart s.1. All from Hole 410. Figures 1 through 4 from Sample 3, CC. 5 through 7 from Sample 2, CC.

1. Spiral view, scale bar $=100 \mu \mathrm{m}$. USNM 249161.

2. Side view of Figure 1, scale bar $=100 \mu \mathrm{m}$.

3. Umbilical view, scale bar $=100 \mu \mathrm{m}$. USNM 249162.

4. Side view, scale bar $=100 \mu \mathrm{m}$. USNM 249163. Figures 1 through 4 could be referred to Globorotalia crassula viola Blow.

5. Side view, scale bar $=100 \mu \mathrm{m}$. USNM 249164.

6. Umbilical view, scale bar $=100 \mu \mathrm{m}$. USNM 249165.

7. Spiral view of Figure 6, scale bar $=100 \mu \mathrm{m}$.

Figures 8,9 Globorotalia cavernula Bé. Both from Hole 412, Sample 1, CC.

8. Side view, scale bar $=100 \mu \mathrm{m}$. USNM 249166.

9. Umbilical view, scale bar $=100 \mu \mathrm{m}$. USNM 249167.

Figures 10-12 Globigerinoides seigliei Bermudez and Bolli. Both from Hole 410, Sample 29, CC.

10. Umbilical view, scale bar $=100 \mu \mathrm{m}$. USNM 249168.

11. Side view of Figure 10, scale bar $=100 \mu \mathrm{m}$.

12. Spiral view, scale bar $=100 \mu \mathrm{m}$. USNM 249169. 
PLATE 3

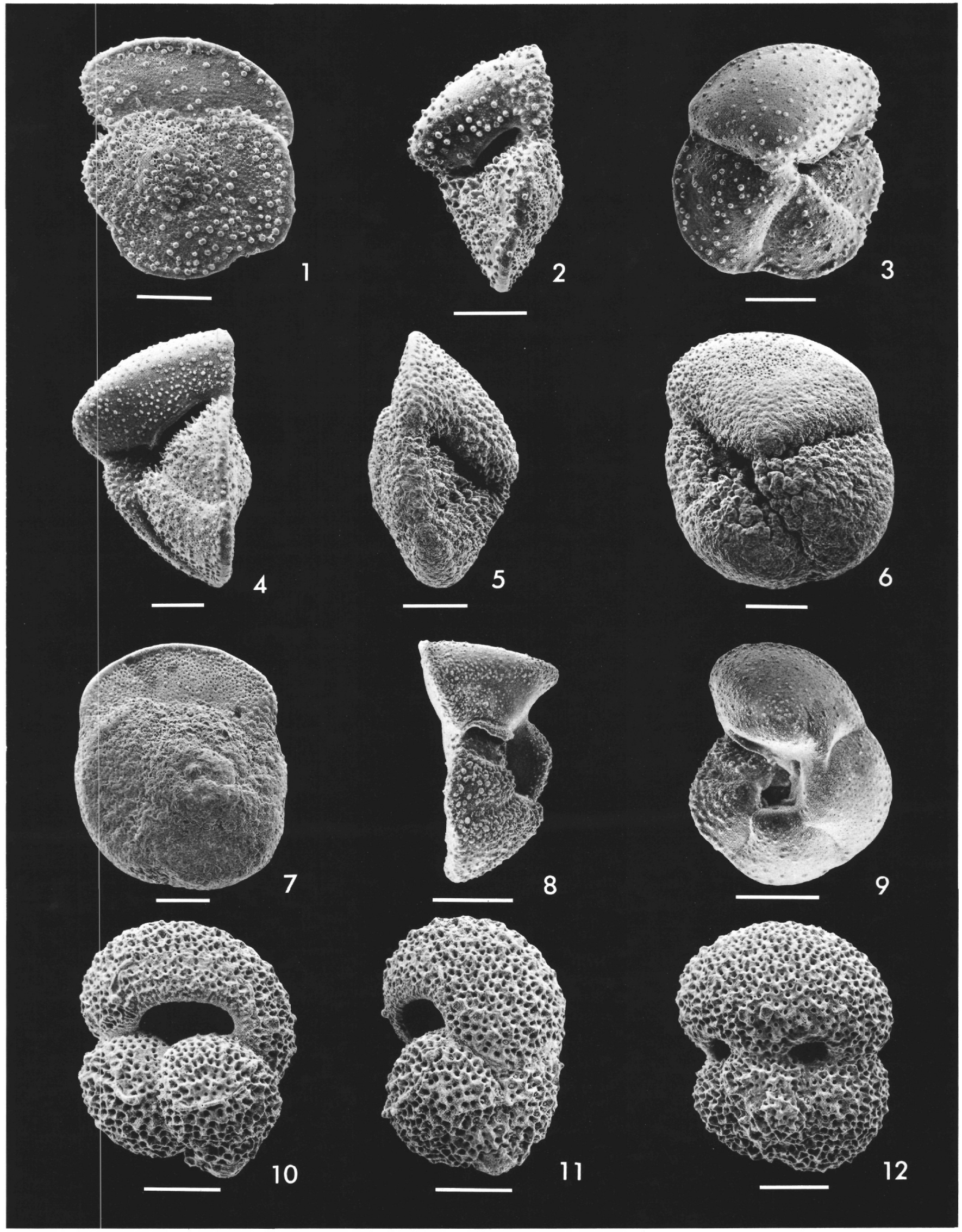




\section{PLATE 4}

Figures 1-3 Globorotalia praehirsuta Blow. Hole 410, Sample 24, CC.

1. Umbilical view, scale bar $=100 \mu \mathrm{m}$. USNM 249170.

2. Side view of Figure 1, scale bar $=100 \mu \mathrm{m}$.

3. Spiral view of Figure 1, scale bar $=100 \mu \mathrm{m}$.

Figures 4-6 Globorotalia margaritae Bolli and Bermudez. Hole 410, Sample 22-3, 139-141 cm.

4. Umbilical view, scale bar $=100 \mu \mathrm{m}$. USNM 249171.

5. Side view of Figure 4, scale bar $=100 \mu \mathrm{m}$.

6. Spiral view of Figure 4, scale bar $=100 \mu \mathrm{m}$.

Figures 7-9 Globorotalia minutissima Bolli. Both from Hole 407, Sample 24-3, 100-102 cm.

7. Umbilical view, scale bar $=30 \mu \mathrm{m}$. USNM 249172.

8. Side view, scale bar $=30 \mu \mathrm{m}$. USNM 249173.

9. Spiral view of Figure 7, scale bar $=30 \mu \mathrm{m}$.

Figures 10-12 Globorotalia ventriosa Ogniben. Hole 410, Sample $25, \mathrm{CC}$.

10. Umbilical view, scale bar $=100 \mu \mathrm{m}$. USNM 249174.

11. Side view of Figure 10, scale bar $=100 \mu \mathrm{m}$.

12. Spiral view of Figure 10, scale bar $=100 \mu \mathrm{m}$. 
PLATE 4
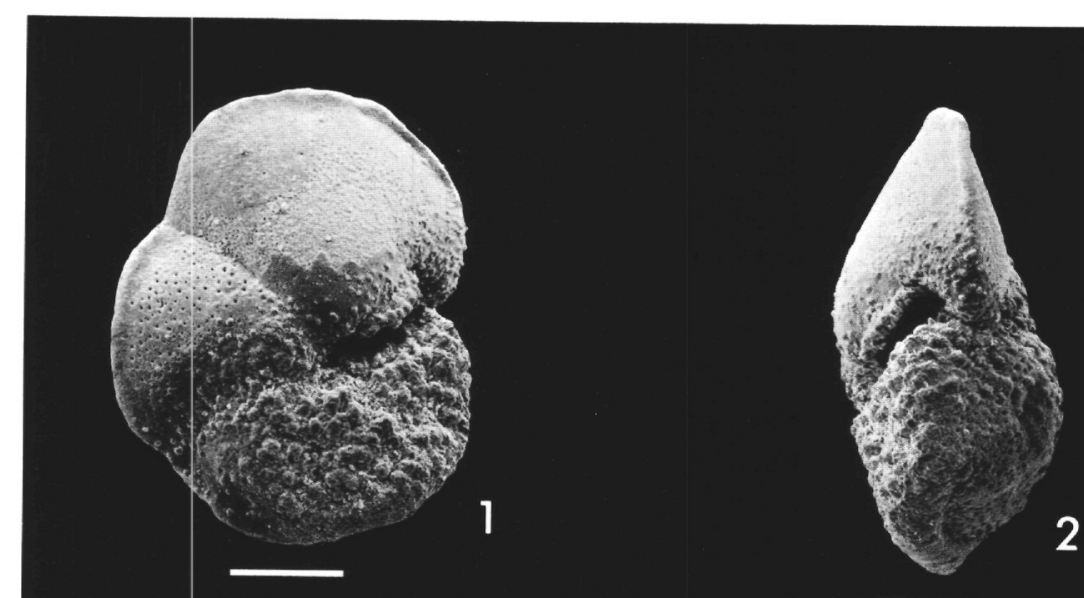

2
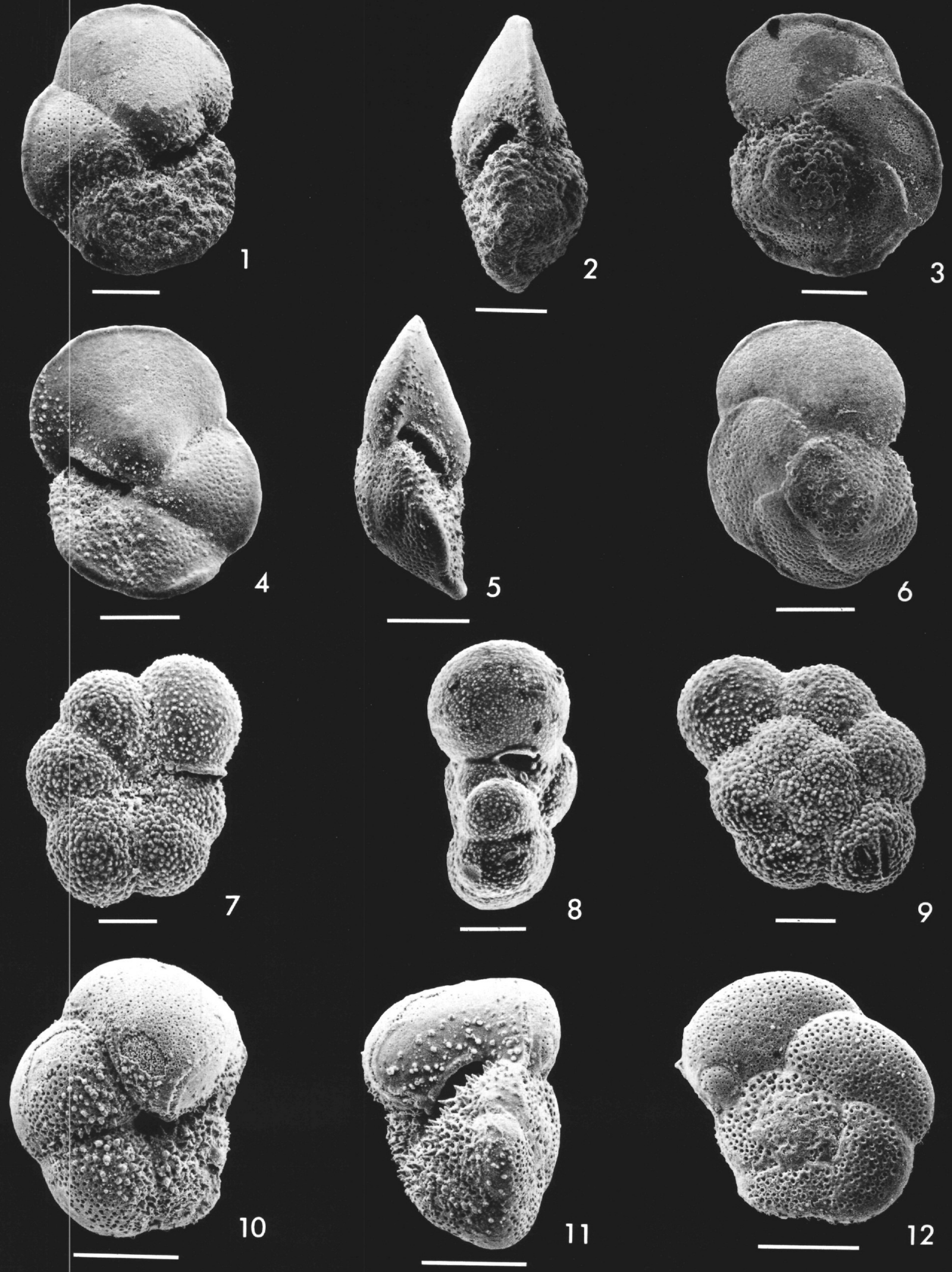


\section{PLATE 5}

Figures 1-3 Globorotalia inflata (d'Orbigny). Both from Hole 412, Sample 1-1, 70-72 cm.

1. Umbilical view, scale bar $=100 \mu \mathrm{m}$. USNM 249175 .

2. Side view of Figure 1, scale bar $=100 \mu \mathrm{m}$.

3. Spiral view, scale bar $=100 \mu \mathrm{m}$. USNM 249176.

Figures 4-6 Globorotalia puncticulata (Deshayes). All from Hole 408, Sample 8, CC.

4. Umbilical view, scale bar $=30 \mu \mathrm{m}$. USNM 249177.

5. Side view, scale bar $=30 \mu \mathrm{m}$. USNM 249178.

6. Spiral view, scale bar $=30 \mu \mathrm{m}$. USNM 249179 .

Figures 7, 8 Globorotalia conomiozea Kennett. Both from Hole 410, Sample 22, CC.

7. Spiral view, scale bar $=100 \mu \mathrm{m}$. USNM 249180.

8. Side view, scale bar $=100 \mu \mathrm{m}$. USNM 249181.

Figures 9-12 Globorotalia conoidea Walters. All from Hole 410, Sample 27, CC.

9. Side view, scale bar $=100 \mu \mathrm{m}$. USNM 249182.

10. Spiral view, scale bar $=30 \mu \mathrm{m}$. USNM 249183.

11. Spiral view, scale bar $=100 \mu \mathrm{m}$. USNM 249184.

12. Umbilical view of Figure 11 , scale bar $=100$ $\mu \mathrm{m}$. 


\section{PLATE 5}

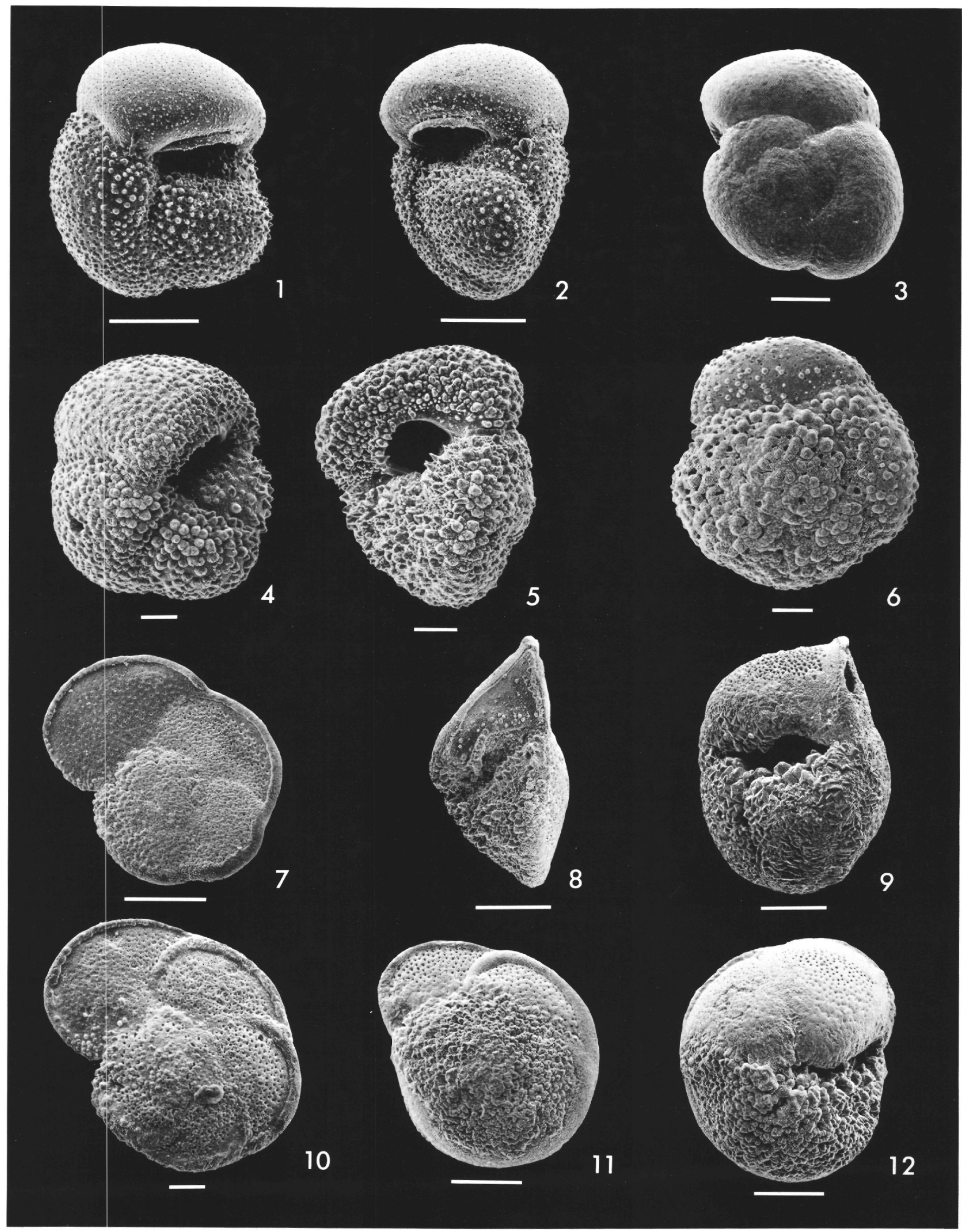




\section{PLATE 6}

Figures 1-3 Globorotalia suterae Catalano and Sprovieri. Hole 410, Sample 25, CC.

1. Umbilical view, scale bar $=100 \mu \mathrm{m}$. USNM 249185.

2. Side view of Figure 1, scale bar $=100 \mu \mathrm{m}$.

3. Spiral view of Figure 1, scale bar $=100 \mu \mathrm{m}$.

Figures 4-7 Globorotalia cf. G. suterae Catalano and Sprovieri. All from Hole 408, Sample 27, CC.

4. Umbilical view, scale bar $=100 \mu \mathrm{m}$. USNM 249186.

5. Umbilical view, scale bar $=100 \mu \mathrm{m}$. USNM 249187.

6. Spiral view of Figure 5, scale bar $=100 \mu \mathrm{m}$.

7. Side view, scale bar $=100 \mu \mathrm{m}$. USNM 249188.

Figures 8-12 Globorotalia miozea Finlay. Both from Hole 408, Sample 30-4, 105-107 cm.

8. Spiral view, scale bar $=100 \mu \mathrm{m}$. USNM 249189.

9. Umbilical view of Figure 8, scale bar $=100 \mu \mathrm{m}$.

10. Side view of Figure 8, scale bar $=100 \mu \mathrm{m}$.

11. Detail of Figure 10, scale bar $=30 \mu \mathrm{m}$.

12. Spiral view, scale bar $=100 \mu \mathrm{m}$. USNM 249190. 


\section{PLATE 6}

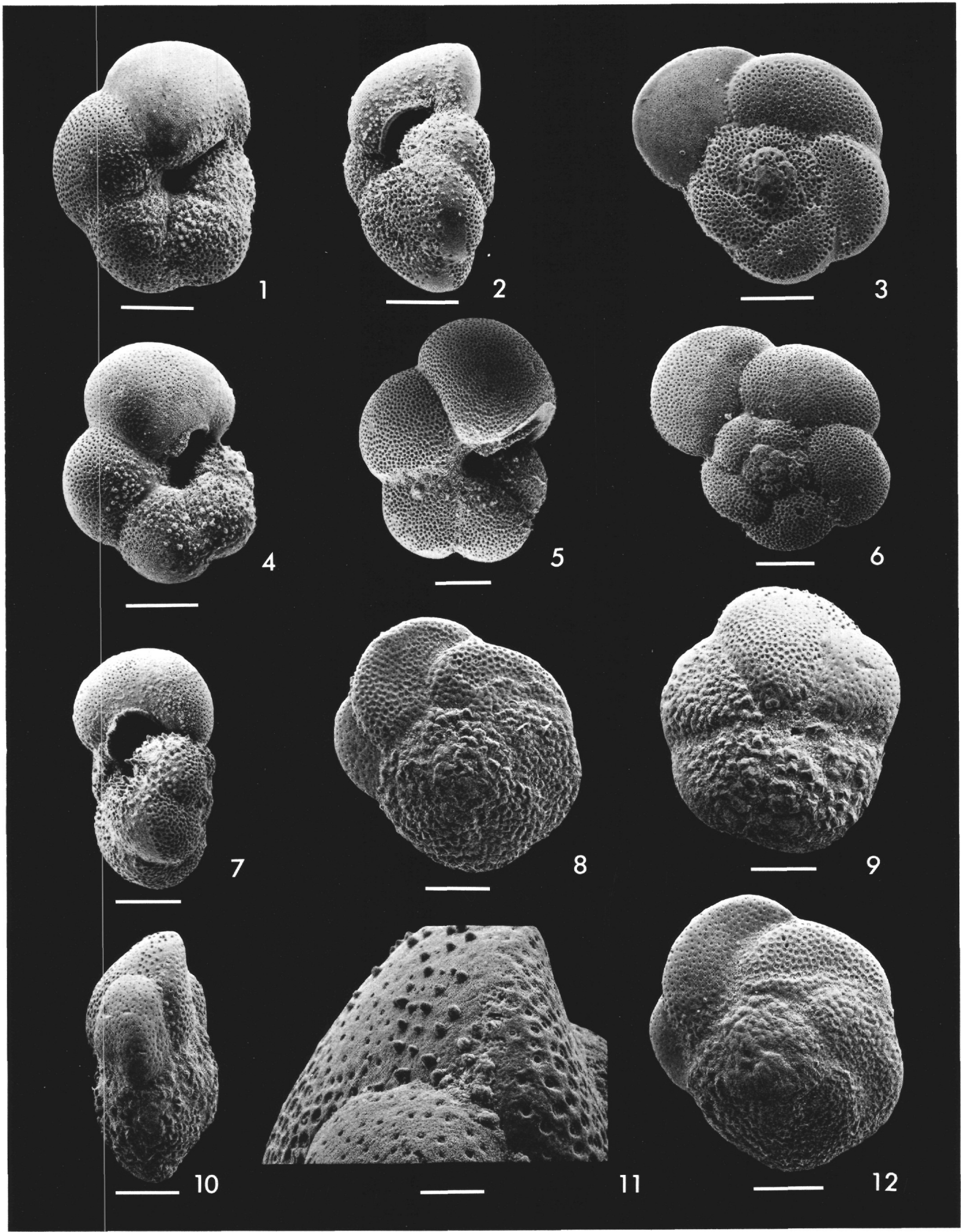




\section{PLATE 7}

Figures 1-3 Globorotalia exserta Romeo. Hole 407, Sample 17-3, $22-24 \mathrm{~cm}$.

1. Umbilical view, scale bar $=100 \mu \mathrm{m}$. USNM 249191.

2. Side view of Figure 1 , scale bar $=100 \mu \mathrm{m}$.

3. Spiral view of Figure 1, scale bar $=100 \mu \mathrm{m}$.

Figures 4-6 Globorotalia peripheroronda Blow and Banner. Both from Hole 408, Sample 30-4, 105-107 cm.

4. Umbilical view, scale bar $=30 \mu \mathrm{m}$. USNM 249192.

5. Side view of Figure 4 , scale bar $=30 \mu \mathrm{m}$.

6. Spiral view, scale bar $=30 \mu \mathrm{m}$. USNM 249193.

Figures 7-9 Globorotalia praescitula Blow. Both from Hole 408, Sample 31-4, 100-102 cm.

7. Umbilical view, scale bar $=100 \mu \mathrm{m}$. USNM 249194.

8. Side view of Figure 7, scale bar $=100 \mu \mathrm{m}$.

9. Spiral view, scale bar $=100 \mu \mathrm{m}$. USNM 249195.

Figures 10-12 Globorotalia zealandica Hornibrook. Both from Hole 408, Sample 32-2, 112-114 cm.

10. Umbilical view, scale bar $=100 \mu \mathrm{m}$. USNM 249196.

11. Side view, scale bar $=30 \mu \mathrm{m}$. USNM 249197.

12. Spiral view of Figure 11, scale bar $=100 \mu \mathrm{m}$. 


\section{PLATE 7}

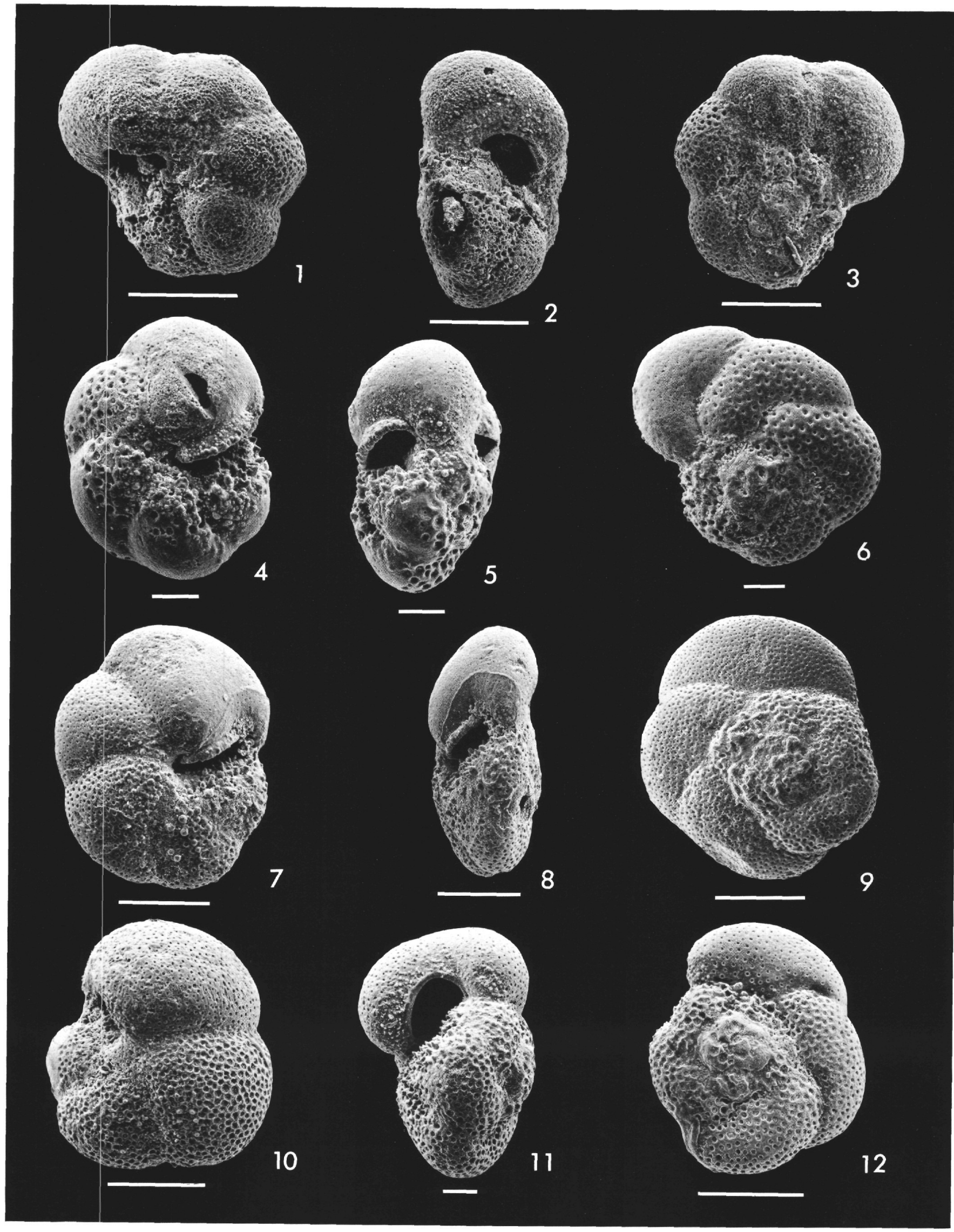




\section{PLATE 8}

Figures 1-3 Globorotalia merotumida Blow and Banner. Hole 410, Sample 35, CC.

1. Umbilical view, scale bar $=100 \mu \mathrm{m}$. USNM 249198.

2. Side view of Figure 1 , scale bar $=100 \mu \mathrm{m}$.

3. Spiral view of Figure 3 , scale bar $=100 \mu \mathrm{m}$.

Figures 4-6 Globorotalia plesiotumida Blow and Banner. Both from Hole 410; Figures 4 and 5: Sample 35, CC; Figure 6: Sample 35-2, 137-139 cm.

4. Umbilical view, scale bar $=100 \mu \mathrm{m}$. USNM 249199.

5. Side view of Figure 4, scale bar $=100 \mu \mathrm{m}$.

6. Spiral view, scale bar $=100 \mu \mathrm{m}$. USNM 249200.

Figures 7-9 Globorotalia tumida (Brady) (primitive form). Hole 410, Sample 23, CC.

7. Umbilical view, scale bar $=100 \mu \mathrm{m}$. USNM 249201.

8. Side view of Figure 7, scale bar $=100 \mu \mathrm{m}$.

9. Spiral view of Figure 7, scale bar $=100 \mu \mathrm{m}$.

Figures 10-12 Globorotalia lenguaensis Bolli. All from Hole 410, Sample 33, CC.

10. Umbilical view, scale bar $=30 \mu \mathrm{m}$. USNM 249202.

11. Side view, scale bar $=30 \mu \mathrm{m}$. USNM 249203.

12. Spiral view, scale bar $=30 \mu \mathrm{m}$. USNM 249204. 


\section{PLATE 8}

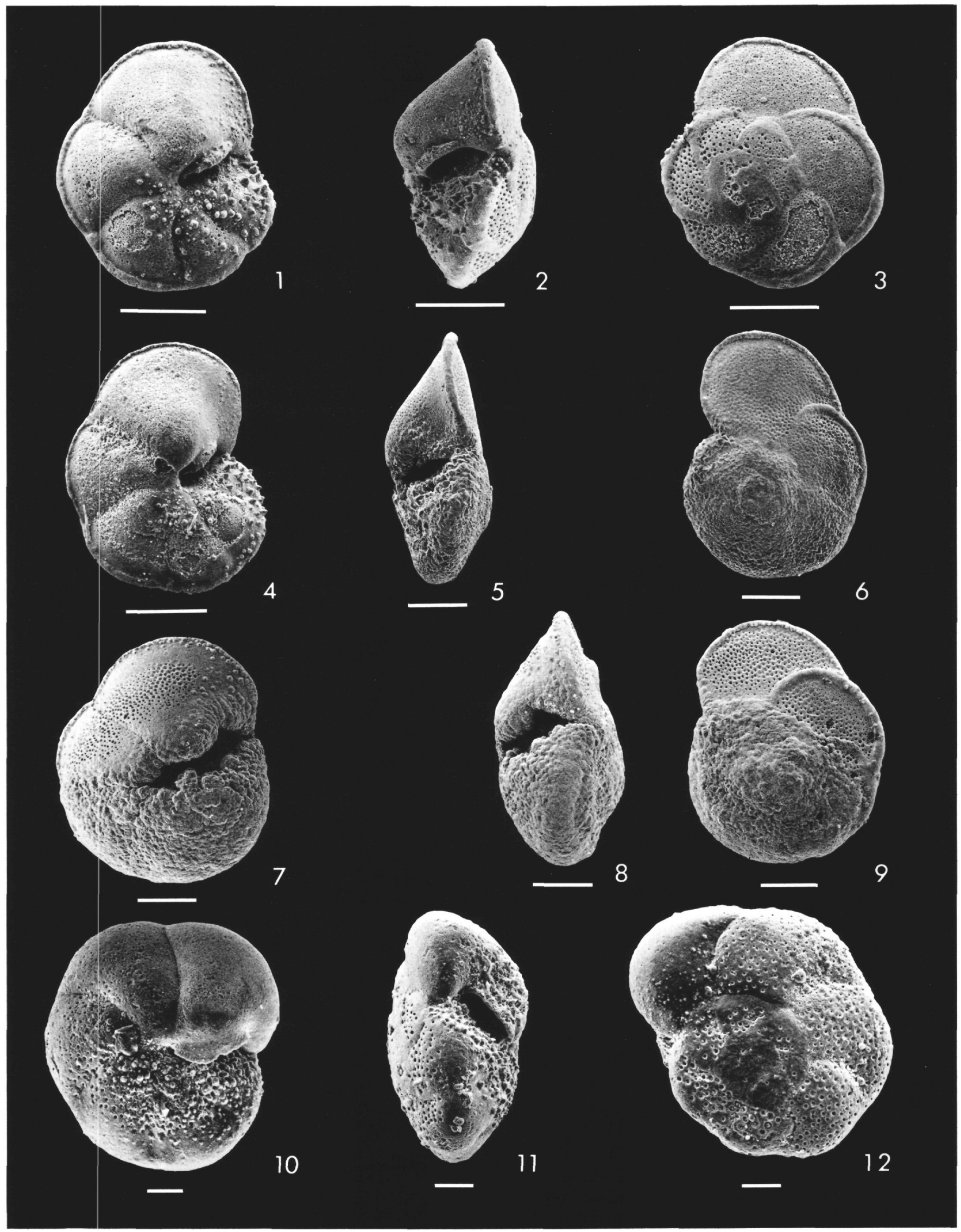




\section{PLATE 9}

Figures 1-5 Globorotalia mayeri Cushman and Ellisor. Figure 1: Hole 408, Sample 25, CC. Figures 2 through 5: Hole 407, Sample 19, CC.

1. Umbilical view, scale bar $=100 \mu \mathrm{m}$. USNM 249205.

2. Side view, scale bar $=30 \mu \mathrm{m}$. USNM 249206.

3. Spiral view of Figure 2, scale bar $=30 \mu \mathrm{m}$.

4. Umbilical view of Figure 2, scale bar $=30 \mu \mathrm{m}$.

5. Side view, scale bar $=30 \mu \mathrm{m}$. USNM 249207.

Figures 6-9 Globorotalia acrostoma Wezel. Figures 6 and 8: Hole 408, Sample 33-4, 130-132 cm. Figures 7 and 9: Hole 407, Sample 19, CC.

6. Umbilical view, scale bar $=30 \mu \mathrm{m}$. USNM 249208.

7. Umbilical view, scale bar $=30 \mu \mathrm{m}$. USNM 249209.

8. Side view, scale bar $=100 \mu \mathrm{m}$. USNM 249210.

9. Spiral view, scale bar $=30 \mathrm{~mm}$. USNM 249211 .

Figures 10-12 Globorotalia continuosa Blow. Hole 408, Sample 20, CC.

10. Umbilical view, scale bar $=30 \mu \mathrm{m}$. USNM 249212.

11. Side view of Figure 10 , scale bar $=100 \mu \mathrm{m}$.

12. Spiral view of Figure 10, scale bar $=100 \mu \mathrm{m}$. 
PLATE 9




PLATE 10

Figures 1-3 Globorotalia kugleri Bolli. Hole 407, Sample 30, CC.

1. Umbilical view, scale bar $=30 \mu \mathrm{m}$. USNM 249213.

2. Side view of Figure 1 , scale bar $=30 \mu \mathrm{m}$.

3. Spiral view of Figure 1, scale bar $=30 \mu \mathrm{m}$.

Figures 4, 5, 7,8

Globorotalia birnageae Blow. Both from Hole 407, Sample 22, CC.

4. Umbilical view, scale bar $=30 \mu \mathrm{m}$. USNM 249214.

5. Spiral view of Figure 4, scale bar $=30 \mu \mathrm{m}$.

7. Spiral view, scale bar $=30 \mu \mathrm{m}$. USNM 249215 .

8. Side view of Figure 7, scale bar $=30 \mu \mathrm{m}$.

Figure 6

Globorotalia pseudokugleri Blow. Hole 407, Sample $31-4,27-29 \mathrm{~cm}$. Spiral view, scale bar $=30 \mu \mathrm{m}$. USNM 249216.

Figure 9 Globigerinoides sicanus de Stefani.Hole 408, Sample $32-2,112-114 \mathrm{~cm}$. Side view, scale bar $=100 \mu \mathrm{m}$. USNM 249217.

Figures 10-12 Globigerinoides subquadratus Brönnimann. Hole 408, Sample 34-2, 122-124 cm.

10. Umbilical view, scale bar $=100 \mu \mathrm{m}$. USNM 249218.

11. Spiral view of Figure 10, scale bar $=100 \mu \mathrm{m}$.

12. Side view of Figure 10, scale bar $=100 \mu \mathrm{m}$. 


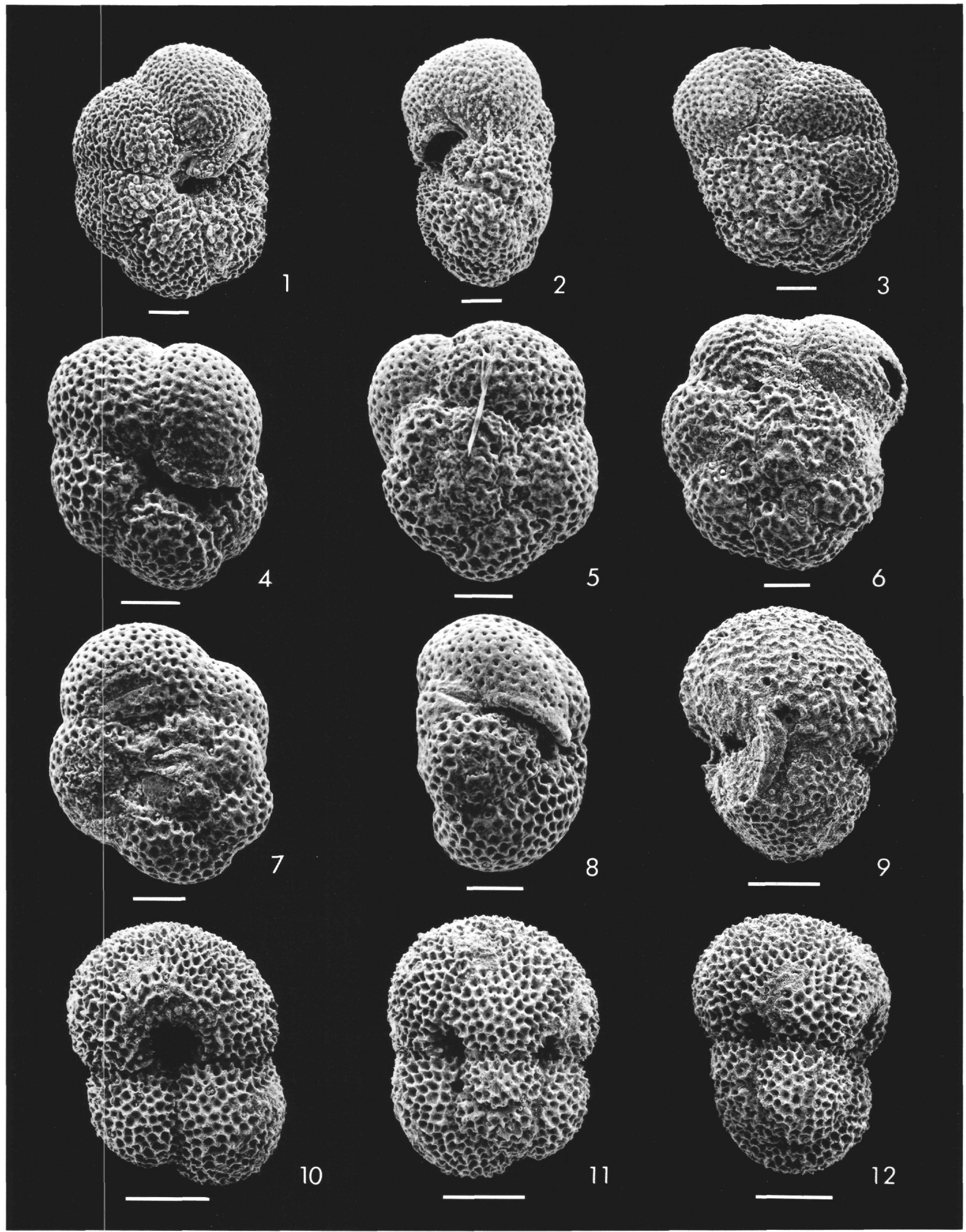




\section{PLATE 11}

Figures 1-6 Globigerinoides cf. G. ruber (d'Orbigny). Hole 407. Figures 1 and 2, 4 and 5: Sample 27, CC. Figures 3 and 6: Sample 29, CC.

1. Umbilical view, scale bar $=100 \mu \mathrm{m}$. USNM 249219.

2. Side view of Figure 1, scale bar $=100 \mu \mathrm{m}$.

3. Umbilical view, scale bar $=100 \mu \mathrm{m}$. USNM 249220.

4. Umbilical view, scale bar $=100 \mu \mathrm{m}$. USNM 249221.

5. Spiral view, scale bar $=100 \mu \mathrm{m}$. USNM 249222.

6. Spiral view of Figure 3, scale bar $=100 \mu \mathrm{m}$.

Figures 7, 8 Globigerinoides primordius Blow and Banner. Hole 407, Sample 30, CC.

7. Umbilical view, scale bar $=100 \mu \mathrm{m}$. USNM 249223.

8. Spiral view of Figure 7, scale bar $=100 \mu \mathrm{m}$.

Figures 9, 12 Globigerinoides obliquus extremus Bolli and Bermudez. Hole 410, Sample 26, CC.

9. Umbilical view, scale bar $=100 \mu \mathrm{m}$. USNM 249224.

12. Spiral view of Figure 9, scale bar $=100 \mu \mathrm{m}$.

Figures 10, 11 Globigerinoides obliquus obliquus Bolli. Hole 410, Sample 29, CC.

10. Umbilical view, scale bar $=100 \mu \mathrm{m}$. USNM 249225.

11. Spiral view of Figure 10 , scale bar $=100 \mu \mathrm{m}$. 


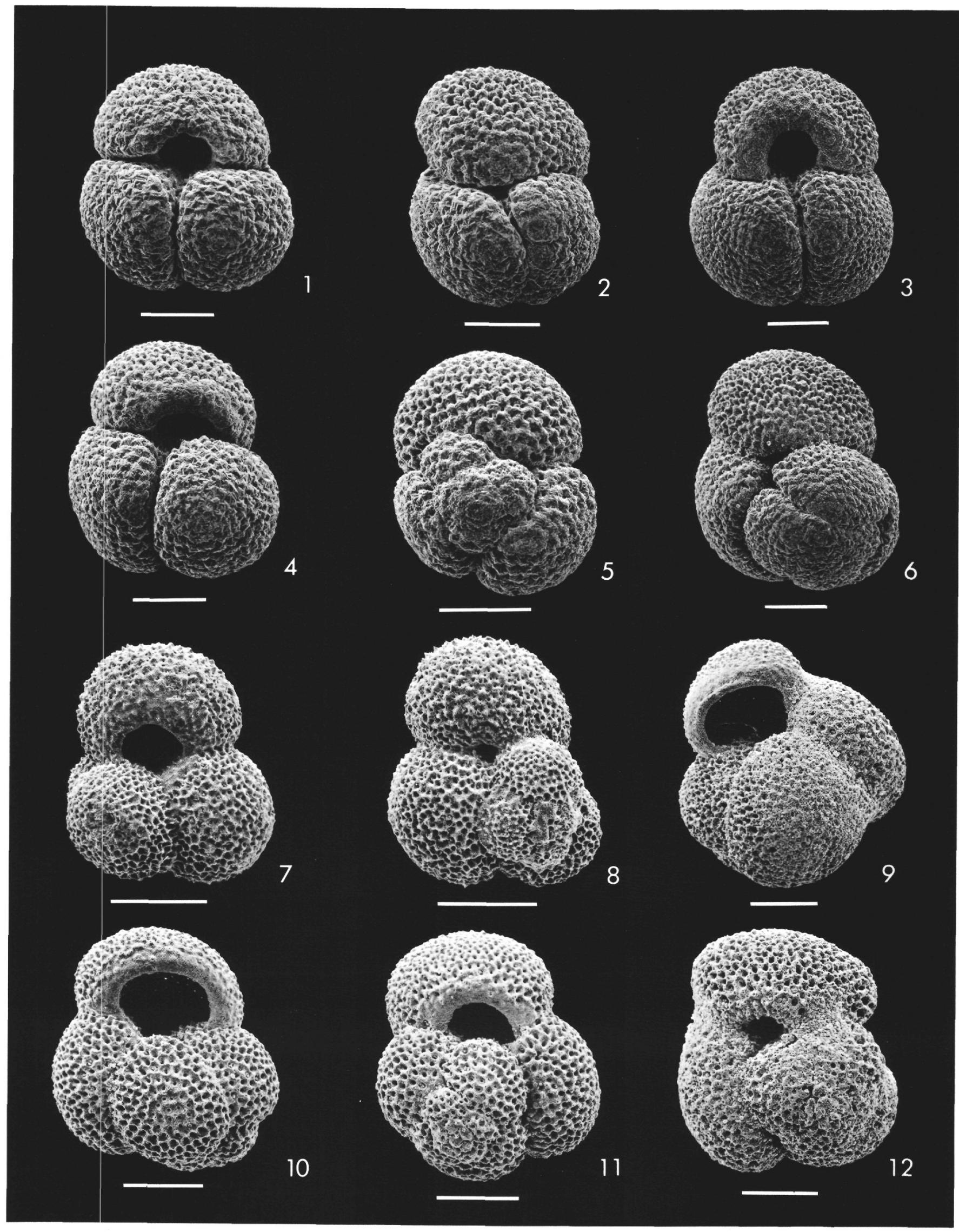




\section{PLATE 12}

Figures 1-3 Globigerina druryi Akers. All from Hole 408, Sample 26, CC.

1. Umbilical view, scale bar $=30 \mu \mathrm{m}$. USNM 249226.

2. Spiral view, scale bar $=30 \mu \mathrm{m}$. USNM 249227.

3. Side view, scale bar $=30 \mu \mathrm{m}$. USNM 249228 .

Figures 4, 5 Globigerina nepenthes Todd. Both from Hole 410, Sample 33, CC.

4. Umbilical view, scale bar $=100 \mu \mathrm{m}$. USNM 249229.

5. Spiral view, scale bar $=100 \mu \mathrm{m}$. USNM 249230.

Figures 6, 9 Globigerina connecta Jenkins. Hole 408, Sample 34-2, 122-124 cm.

6. Spiral view, scale bar $=100 \mu \mathrm{m}$. USNM 249231.

9. Umbilical view of Figure 6, scale bar $=100 \mu \mathrm{m}$.

Figures 7, 8 Globigerina decoraperta Takayanagi and Saito. Hole 410, Sample 29, CC.

7. Spiral view, scale bar $=30 \mu \mathrm{m}$. USNM 249232.

8. Umbilical view of Figure 7 , scale bar $=30 \mu \mathrm{m}$.

Figures 10-12 Globigerina falconensis Blow. Both from Hole 407, Sample 19, CC.

10. Umbilical view, scale bar $=30 \mu \mathrm{m}$. USNM 249233.

11. Spiral view, scale bar $=30 \mu \mathrm{m}$. USNM 249234.

12. Umbilical view of Figure 11 , scale bar $=30 \mu \mathrm{m}$. 


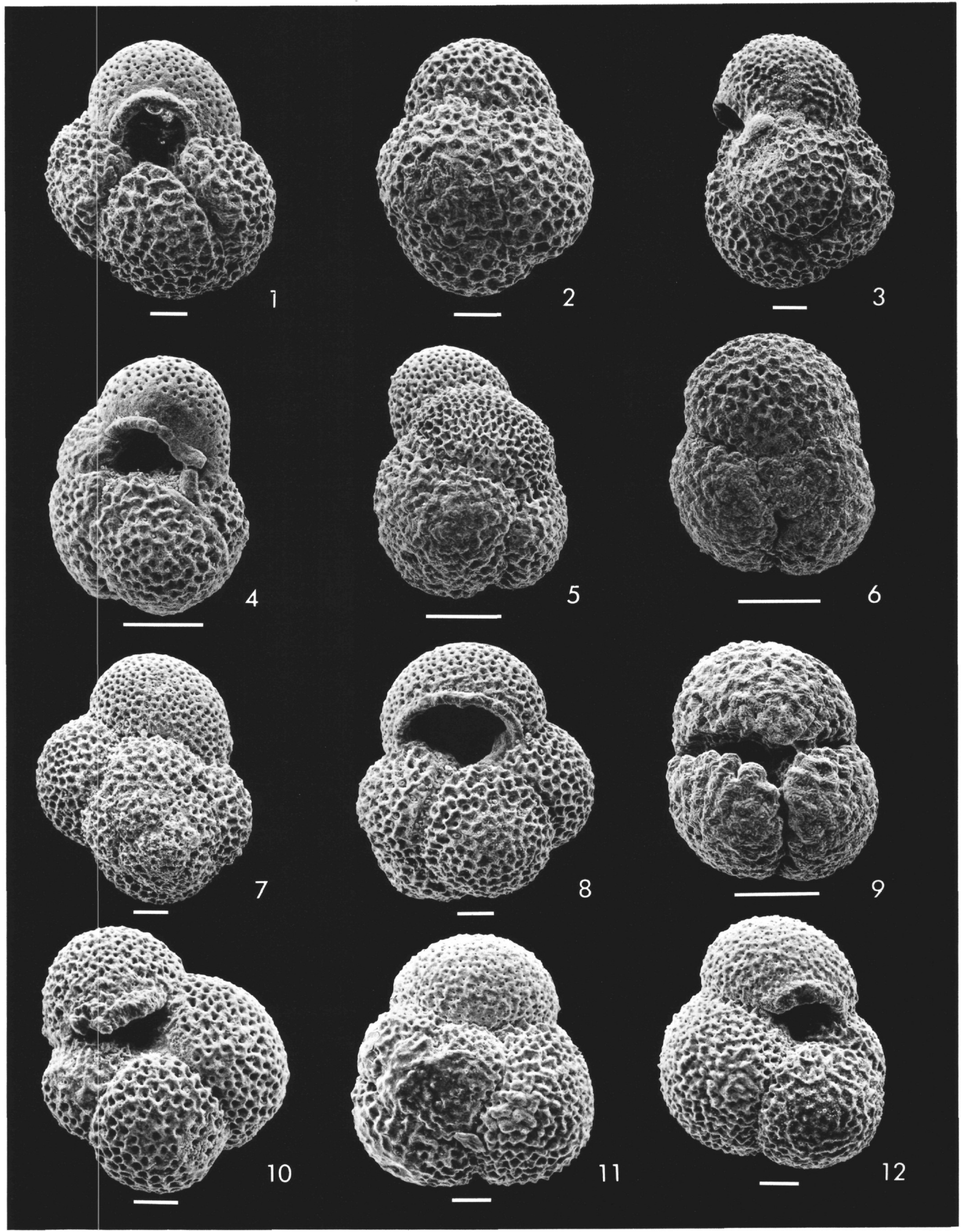




\section{PLATE 13}

Figures 1-4 Globigerina woodi Jenkins. Figures 1 and 2: Hole 410, Sample 33, CC. Figures 3 and 4: Hole 408, Sample 18-3, 40-42 cm.

1. Umbilical view, scale bar $=30 \mu \mathrm{m}$. USNM 249235.

2. Spiral view, scale bar $=100 \mu \mathrm{m}$. USNM 249236.

3. Umbilical view, scale bar $=100 \mu \mathrm{m}$. USNM 249237.

4. Spiral view, scale bar $=30 \mu \mathrm{m}$. USNM 249238 .

Figures 5-10 Globigerina woodi Jenkins (variant). All from Hole 408, Sample 32, CC.

5. Umbilical view, scale bar $=100 \mu \mathrm{m}$. USNM 249239.

6. Umbilical view, scale bar $=100 \mu \mathrm{m}$. USNM 249240.

7. Spiral view, scale bar $=100 \mu \mathrm{m}$. USNM 249241.

8. Umbilical view, scale bar $=100 \mu \mathrm{m}$. USNM 249242.

9. Spiral view of Figure 8, scale bar $=100 \mu \mathrm{m}$.

10. Oblique side view, scale bar $=100 \mu \mathrm{m}$. USNM 249243.

Figures 11, 12 Globigerina apertura Cushman. Both from Hole 410, Sample 33, CC.

11. Umbilical view, scale bar $=100 \mu \mathrm{m}$. USNM 249244.

12. Spiral view, scale bar $=100 \mu \mathrm{m}$. USNM 249245. 
PLATE 13

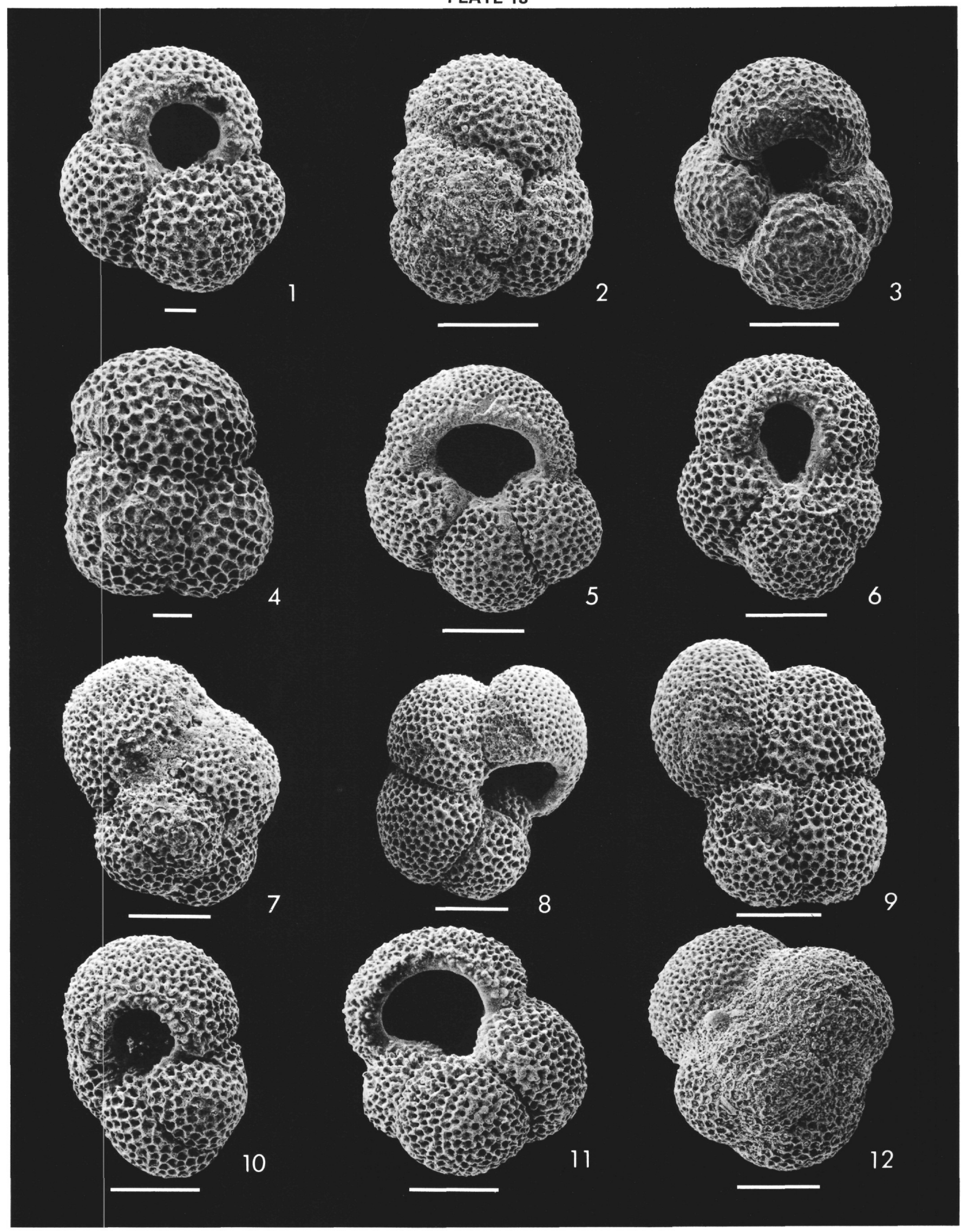




\section{PLATE 14}

Figures 1-3 Sphaeroidinellopsis seminulina (Schwager). Both from Hole 408, Sample 31-4, 100-102 cm.

1. Umbilical view, scale bar $=100 \mu \mathrm{m}$. USNM 249246.

2. Umbilical view, scale bar $=100 \mu \mathrm{m}$. USNM 249247.

3. Spiral view of Figure 2, scale bar $=100 \mu \mathrm{m}$.

Figures 4-7 Globoquadrina venezuelana (Hedberg). All from Hole 407. Figures 4 through 6: Sample 23-1, 40-42 cm; Figure 7: Sample 24-3, 100-102 cm.

4. Oblique umbilical view, scale bar $=100 \mu \mathrm{m}$. USNM 249248.

5. Spiral view of Figure 4 , scale bar $=100 \mu \mathrm{m}$.

6. Umbilical view, scale bar $=100 \mu \mathrm{m}$. USNM 249249.

7. Oblique umbilical view, scale bar $=100 \mu \mathrm{m}$. Note tooth on penultimate chamber. USNM 249250 .

Figures 8, 9 Globigerina pseudociperoensis Blow. Both from Hole 407, Sample 24-3, 100-102 cm.

8. Umbilical view, scale bar $=30 \mu \mathrm{m}$. USNM 249251.

9. Spiral view, scale bar $=30 \mu \mathrm{m}$. USNM 249252.

Figures 10, 11 Globigerina bulbosa LeRoy. Hole 408, Sample 27-2, 40-42 cm.

10. Oblique umbilical view, scale bar $=100 \mu \mathrm{m}$. USNM 249253.

11. Spiral view of Figure 10, scale bar $=100 \mu \mathrm{m}$.

Figure 12 Globigerina umbilicata Orr and Zaitzeff. Hole 407, Sample 7-2, 100-102 cm. Umbilical view, scale bar $=100 \mu \mathrm{m}$. USNM 249254 . 


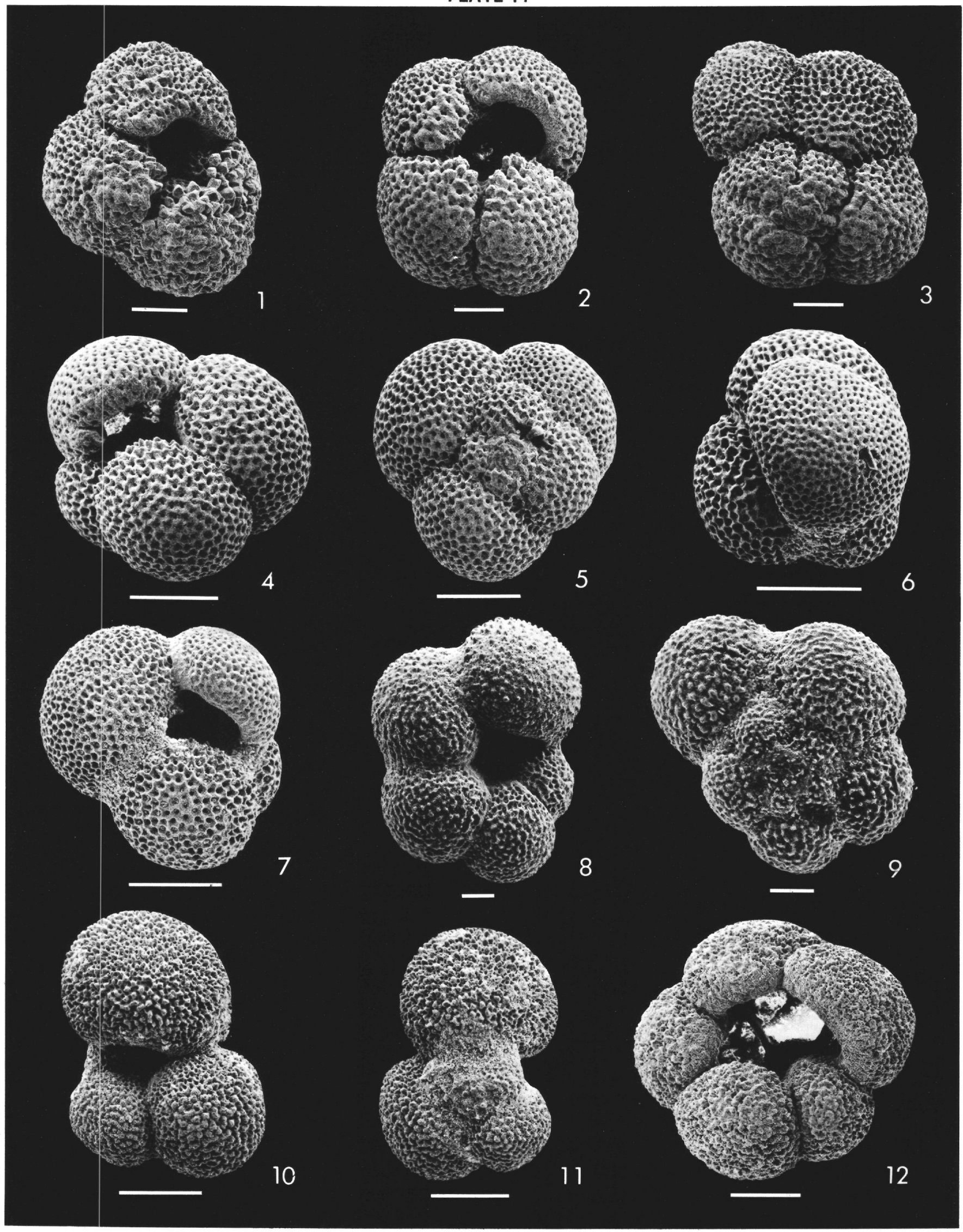


PLATE 15

Figures 1-3 Catapsydrax stainforthi Bolli, Loeblich, and Tappan. Hole 407, Sample 36-2, 52-54 cm.

1. Umbilical view, scale bar $=100 \mu \mathrm{m}$. USNM 249255.

2. Side view of Figure 1, scale bar $=100 \mu \mathrm{m}$.

3. Spiral view of Figure 1 , scale bar $=100 \mu \mathrm{m}$.

Figure 4 Catapsydrax dissimilis dissimilis (Cushman and Bermudez). Hole 407, Sample 36-1, 132-134 cm. Umbilical view, scale bar $=30 \mu \mathrm{m}$. USNM 249256 .

Figure 5 Catapsydrax dissililis ciperoensis (Blow and Banner). Hole 407, Sample 36-1, 132-134 cm. Umbilical view, scale bar $=100 \mu \mathrm{m}$. USNM 249257.

Figure 6 Globigerina anguliofficinalis Blow. Hole 407, Sample $36-2,52-54 \mathrm{~cm}$. Umbilical view, scale bar $=30$ $\mu \mathrm{m}$. USNM 249258.

Figures 7, 8 Globigerinita praestainforthi Blow. Hole 407, Sample $36-2,52-54 \mathrm{~cm}$.

7. Umbilical view, scale bar $=30 \mu \mathrm{m}$. USNM 249259.

8. Spiral view of Figure 8, scale bar $=30 \mu \mathrm{m}$.

Figures 9, 10 Turborotalita quinqueloba (Natland). Both from Hole 409, Sample 7-3, $15-17 \mathrm{~cm}$.

9. Side view, scale bar $=30 \mu \mathrm{m}$. USNM 249260 .

10. Umbilical view, scale bar $=30 \mu \mathrm{m}$. USNM 249261

Figures 11, 12 Globigerina sp. B. Hole 407, Sample 35-1, 100-102 $\mathrm{cm}$.

11. Umbilical view, scale bar $=100 \mu \mathrm{m}$. USNM 249262.

12. Spiral view of Figure 11, scale bar $=100 \mu \mathrm{m}$. 


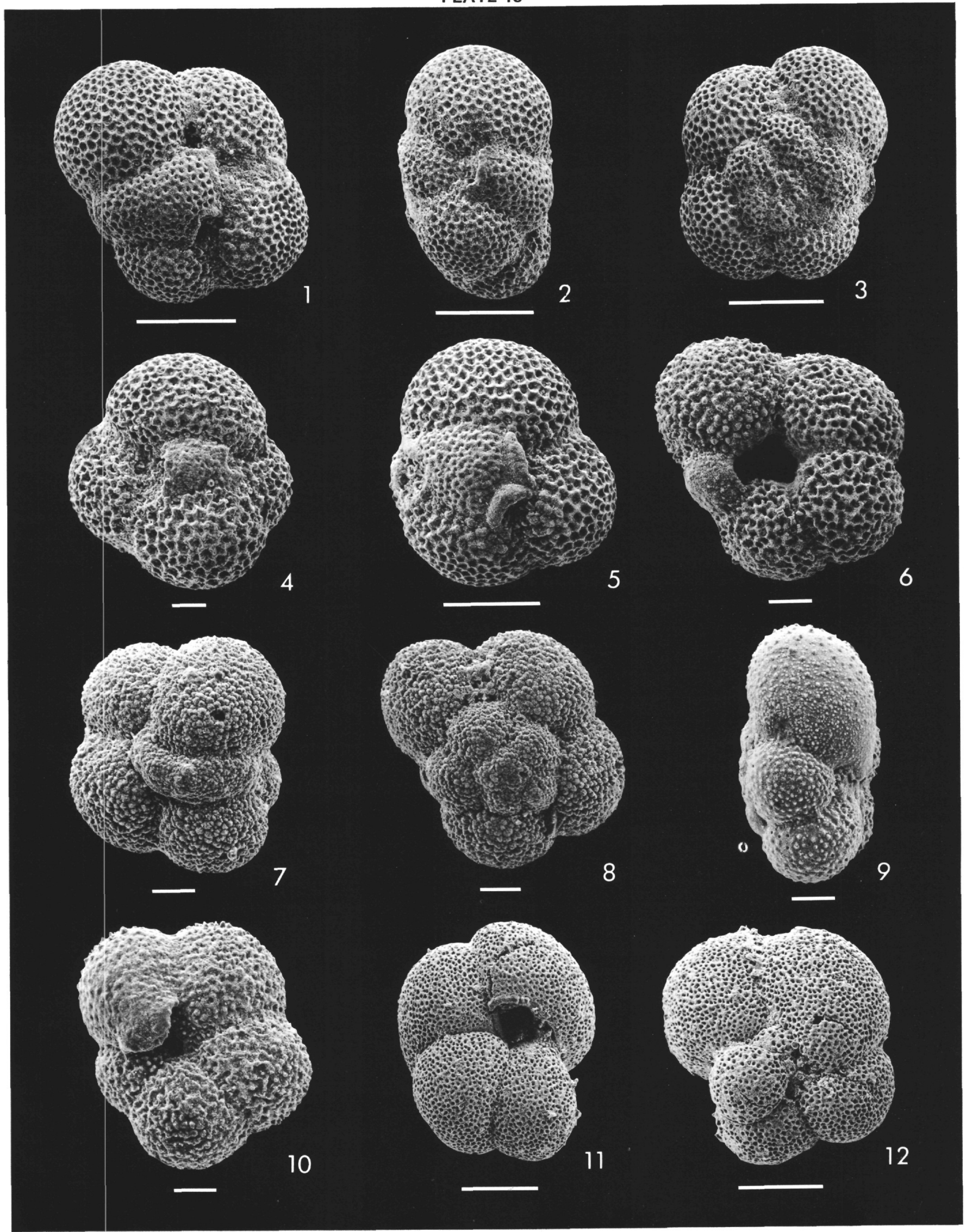




\section{PLATE 16}

Figures 1-9 Negloboquadrina atlantica (Berggren). All from Hole 407. Figures 1 through 4: Sample 14, CC; Figures 5 through 9: Sample 17, CC.

1. Umbilical view, scale bar $=100 \mu \mathrm{m}$. USNM 249263.

2. Umbilical view, scale bar $=100 \mu \mathrm{m}$. USNM 249264.

3. Umbilical view, scale bar $=100 \mu \mathrm{m}$. USNM 249265.

4. Spiral view of Figure 3, scale bar $=100 \mu \mathrm{m}$.

5. Umbilical view, scale bar $=100 \mu \mathrm{m}$. USNM 249266.

6. Umbilical view, scale bar $=100 \mu \mathrm{m}$. USNM 249267.

7. Umbilical view, scale bar $=100 \mu \mathrm{m}$. USNM 249268.

8. Side view of Figure 7, scale bar $=100 \mu \mathrm{m}$.

9. Side view of Figure 6 , scale bar $=100 \mu \mathrm{m}$.

Figures 10-12 Neogloboquadrina atlantica (Berggren) primitive form. All from Hole 407, Sample 18-3, 21-23 cm.

10. Umbilical view, scale bar $=100 \mu \mathrm{m}$. USNM 249269.

11. Side view, scale bar $=100 \mu \mathrm{m}$. USNM 249270.

12. Spiral view, scale bar $=100 \mu \mathrm{m}$. USNM 249271. 


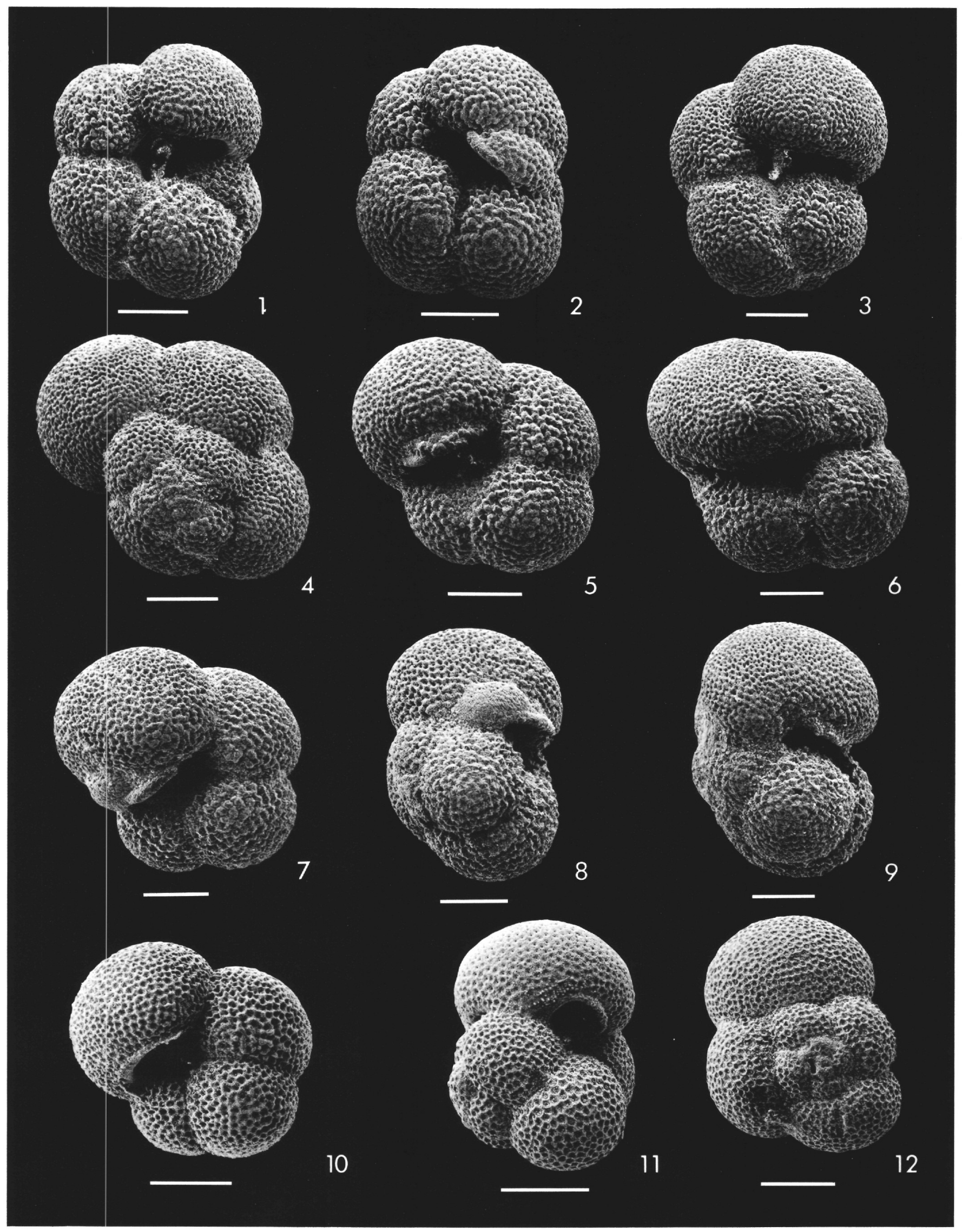




\section{PLATE 17}

Figures 1-3 Neogloboquadrina acostaensis (Blow). Both from Hole 408, Sample 23, CC.

1. Umbilical view, scale bar $=30 \mu \mathrm{m}$. USNM 249272.

2. Spiral view of Figure 1 , scale bar $=30 \mu \mathrm{m}$.

3. Umbilical view, scale bar $=100 \mu \mathrm{m}$. USNM 249273.

Figures 4-6 Neogloboquadrina humerosa (Takayanagi and Saito). Both from Hole 408, Sample 20-2, 70-72 cm.

4. Umbilical view, scale bar $=100 \mu \mathrm{m}$. USNM 249274.

5. Spiral view of Figure 4, scale bar $=100 \mu \mathrm{m}$.

6. Side view, scale bar $=100 \mu \mathrm{m}$. USNM 249275.

7. Umbilical view, scale bar $=30 \mu \mathrm{m}$. USNM 249276.

8. Umbilical view, scale bar $=30 \mu \mathrm{m}$. USNM 249277.

Figure $10 \quad$ Neogloboquadrina pachyderma (Ehrenberg) s.1. Hole 408, Sample 16, CC. Umbilical view, scale bar $=30$ $\mu \mathrm{m}$. USNM 249281.

Figures 9, 11-12 Neogloboquadrina “du/pac." All from Hole 407, Sample 1, CC.

9. Umbilical view, scale bar $=100 \mu \mathrm{m}$. USNM 249278.

11. Umbilical view, scale bar $=100 \mu \mathrm{m}$. USNM 249279.

12. Umbilical view, scale bar $=30 \mu \mathrm{m}$. USNM 249280. 


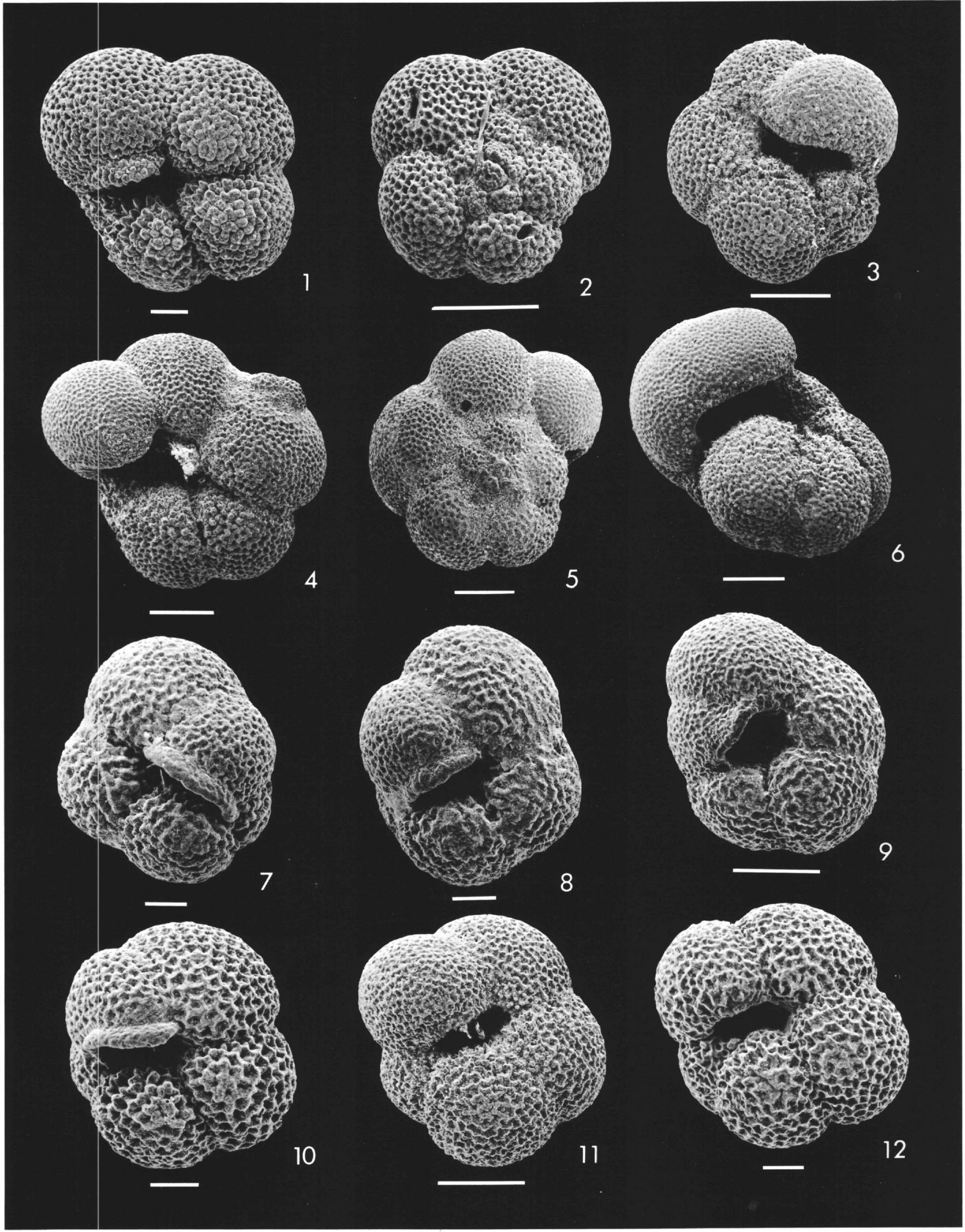




\section{PLATE 18}

Figures 1-3 Globoquadrina larmeui Akers. Hole 407, Sample 18-3, 21-23 cm.

1. Umbilical view, scale bar $=100 \mu \mathrm{m}$. USNM 249282.

2. Side view of Figure 1, scale bar $=100 \mu \mathrm{m}$.

3. Spiral view of Figure 1, scale bar $=100 \mu \mathrm{m}$.

Figures 4-7 Globoquadrina praedehiscens Blow and Banner. Both from Hole 407. Figures 4 through 6: Sample 28-3, 91-92 cm; Figure 7: Sample 31-2, 29-31 cm.

4. Umbilical view bar $=100 \mu \mathrm{m}$. USNM 249283.

5. Side view of Figure 4, scale bar $=100 \mu \mathrm{m}$.

6. Spiral view of Figure 4, scale bar $=100 \mu \mathrm{m}$.

7. Umbilical view, scale bar $=100 \mu \mathrm{m}$. USNM 249284.

Figures 8-12 Globoquadrina baroemoenensis (LeRoy). All from Hole 408. Figures 8 and 9: Sample 34-2, 122-124 cm; Figures 10 through 12: Sample 31, CC.

8. Umbilical view, scale bar $=100 \mu \mathrm{m}$. USNM 249285

9. Side view, scale bar $=100 \mu \mathrm{m}$. USNM 249286.

10. Umbilical view, scale bar $=100 \mu \mathrm{m}$. USNM 249287.

11. Spiral view of Figure 10 , scale bar $=100 \mu \mathrm{m}$.

12. Oblique side view of Figure 10 , scale bar $=100$ $\mu \mathrm{m}$. 

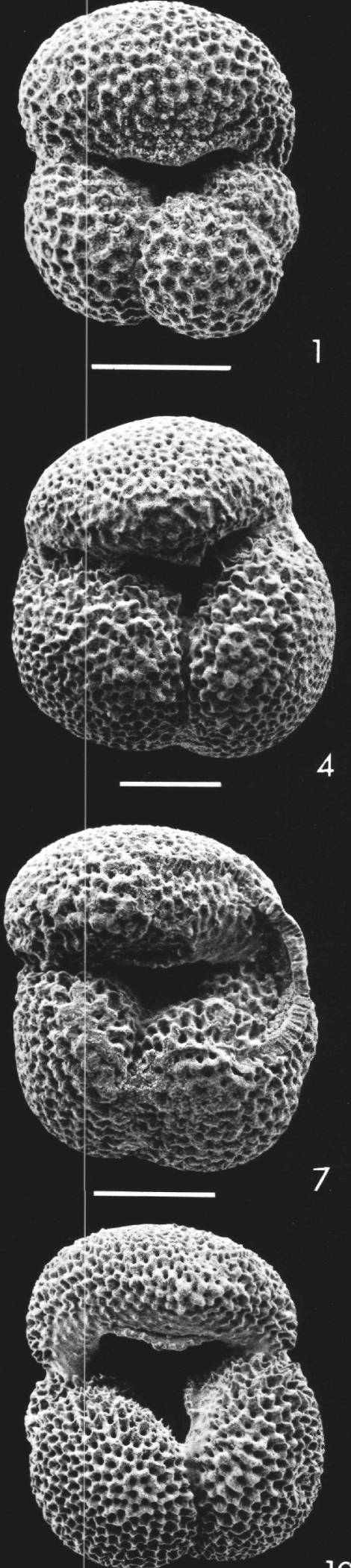
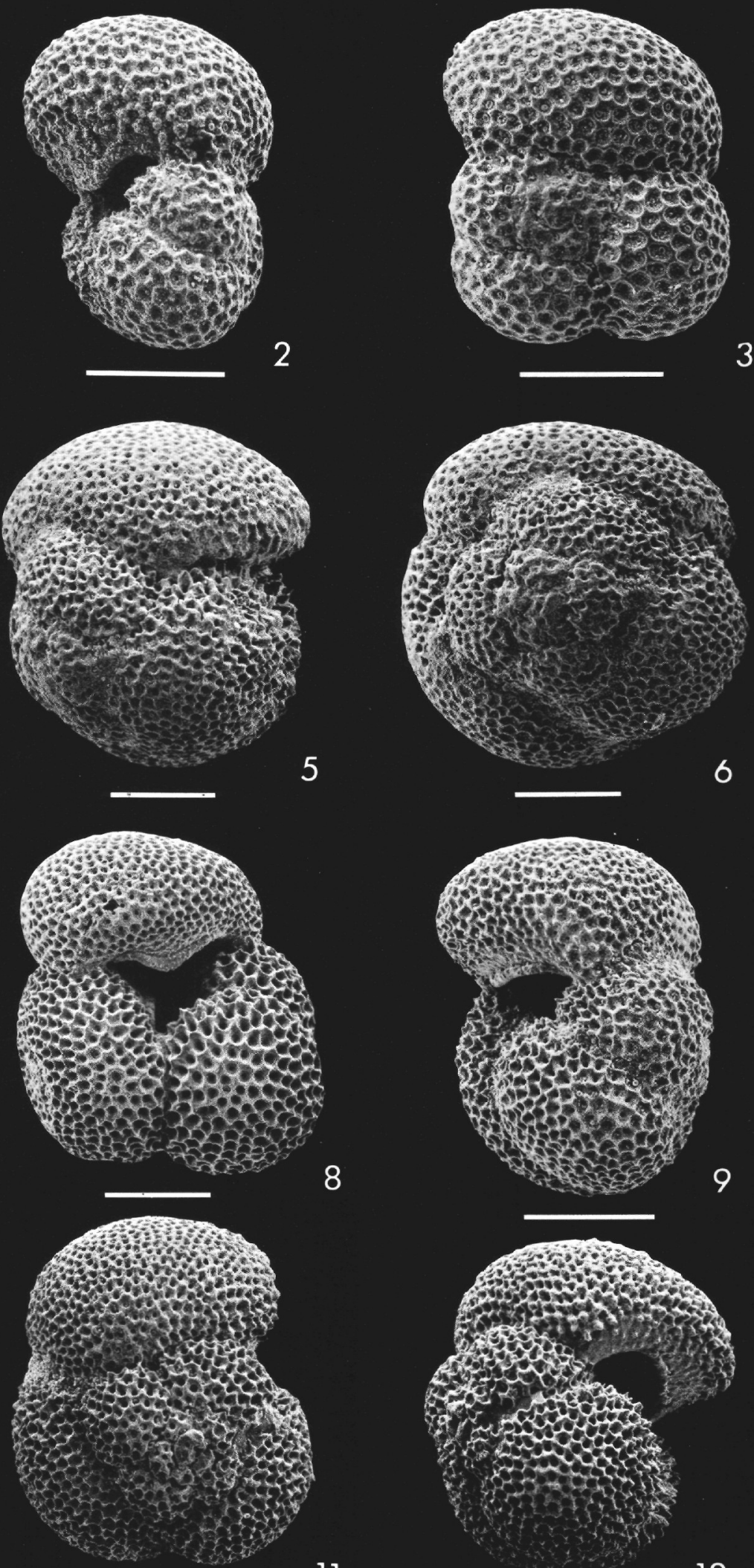


\section{PLATE 19}

Figures 1-4 Hastigerinopsis riedeli (Rögl and Bolli). All from Hole 407, Sample 2-2, $57-59 \mathrm{~cm}$.

1. Umbilical view, scale bar $=30 \mu \mathrm{m}$. USNM 249288.

2. Spiral view, scale bar $=30 \mu \mathrm{m}$. USNM 249289.

3. Umbilical view, scale bar $=30 \mu \mathrm{m}$. USNM 249290.

4. Side view, scale bar $=30 \mu \mathrm{m}$. USNM 249291.

Figures 5-12 Globigerina sp. A. All from Hole 409. Figures 5, 7, and 9 through 12: Sample 5-3, 21-23 cm; Figure 6: Sample 7-5, 40-42 cm; Figure 8: Sample 7-3, 15-17 $\mathrm{cm}$.

5. Oblique side view, scale bar $=30 \mu \mathrm{m}$. USNM 249292.

6. Spiral view, scale bar $=30 \mu \mathrm{m}$. USNM 249293.

7. Umbilical view, scale bar $=30 \mu \mathrm{m}$. USNM 249294.

8. Side view, scale bar $=30 \mu \mathrm{m}$. USNM 249295 .

9. Umbilical view, scale bar $=100 \mu \mathrm{m}$. USNM 249296.

10. Umbilical view, scale bar $=30 \mu \mathrm{m}$. USNM 249297.

11. Umbilical view, scale bar $=30 \mu \mathrm{m}$. USNM 249298.

12. Spiral view, scale bar $=30 \mu \mathrm{m}$. USNM 249299. 


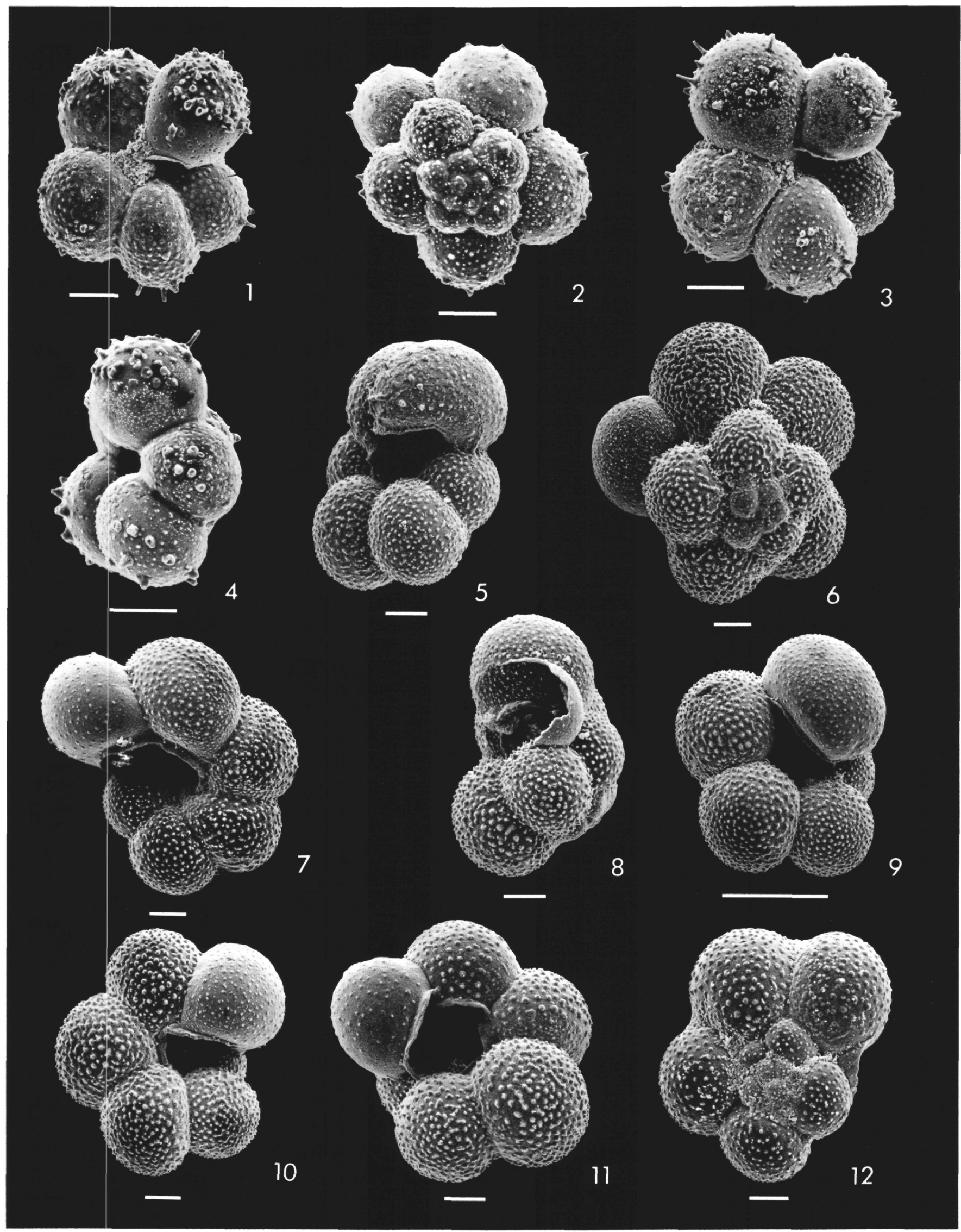




\section{PLATE 20}

Figures 1, 2 Chiloguembelina cubensis (Palmer). Both from Hole 407, Sample 43, CC.

1. Edge view, scale bar $=0 \mu \mathrm{m}$. USNM 249300.

2. Side view, scale bar $=30 \mu \mathrm{m}$. USNM 249301 .

Figures 3, 4 Cassigerinella chipolensis (Cushman and Ponton). Hole 407, Sample 24-3, 100-102 cm.

3. Edge view, scale bar $=30 \mu \mathrm{m}$. USNM 249302.

4. Detail of penultimate chamber of Figure 3, scale bar $=10 \mu \mathrm{m}$.

Figures 5, 6 Globigerina angiporoides Hornibrook. Both from Hole 407, Sample 43, CC.

5. Umbilical view, scale bar $=30 \mu \mathrm{m}$. USNM 249303.

6. Spiral view, scale bar н $30 \mu \mathrm{m}$. USNM 249304.

Figure 7 Globigerina ouachitaensis Howe and Wallace. Hole 407, Sample 35-1, 100-102 cm. Umbilical view, scale bar $=30 \mu \mathrm{m}$. USNM 249305 .

Figures 8-10 Globorotalia munda Jenkins. Both from Hole 407, Sample 43, CC.

8. Umbilical view, scale bar $=30 \mu \mathrm{m}$. USNM 249306.

9. Spiral view, scale bar $=30 \mu \mathrm{m}$. USNM 249307 .

10. Side view of Figure 8, scale bar $=30 \mu \mathrm{m}$.

Figures 11-13 Globorotalia cf. G. munda Jenkins. Both from Hole 407. Figures 11 and 12: Sample 31-4, 27-29 cm; Figure 13: Sample 31-2, 29-31 cm.

11. Umbilical view, scale bar $=30 \mu \mathrm{m}$. USNM 249308.

12. Spiral view of Figure 11, scale bar $=30 \mu \mathrm{m}$.

13. Side view, scale bar $=30 \mu \mathrm{m}$. USNM 249309. 

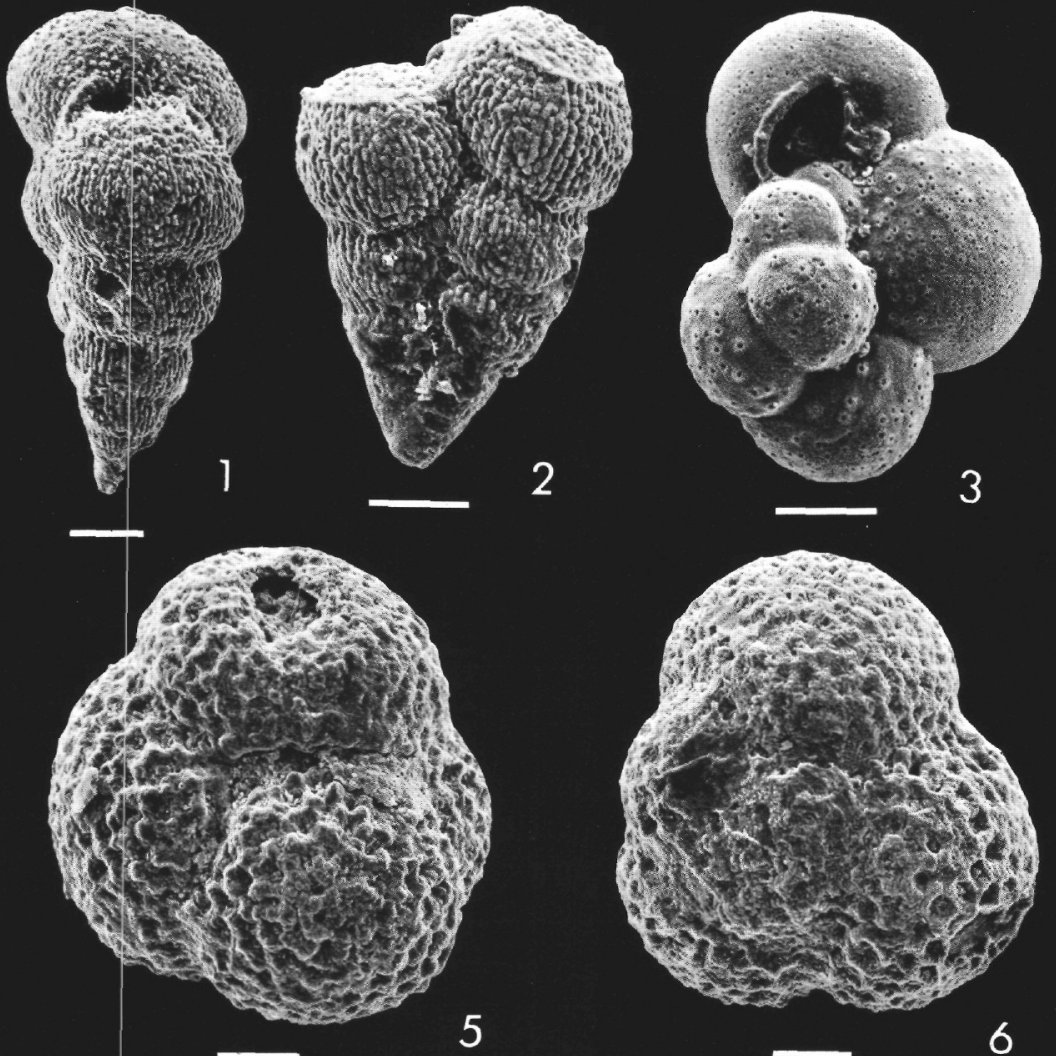

5

8
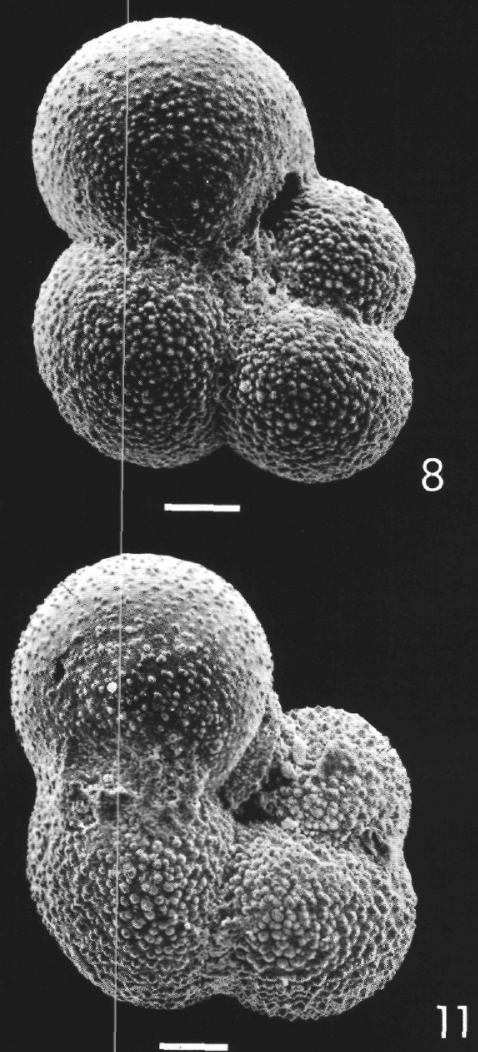
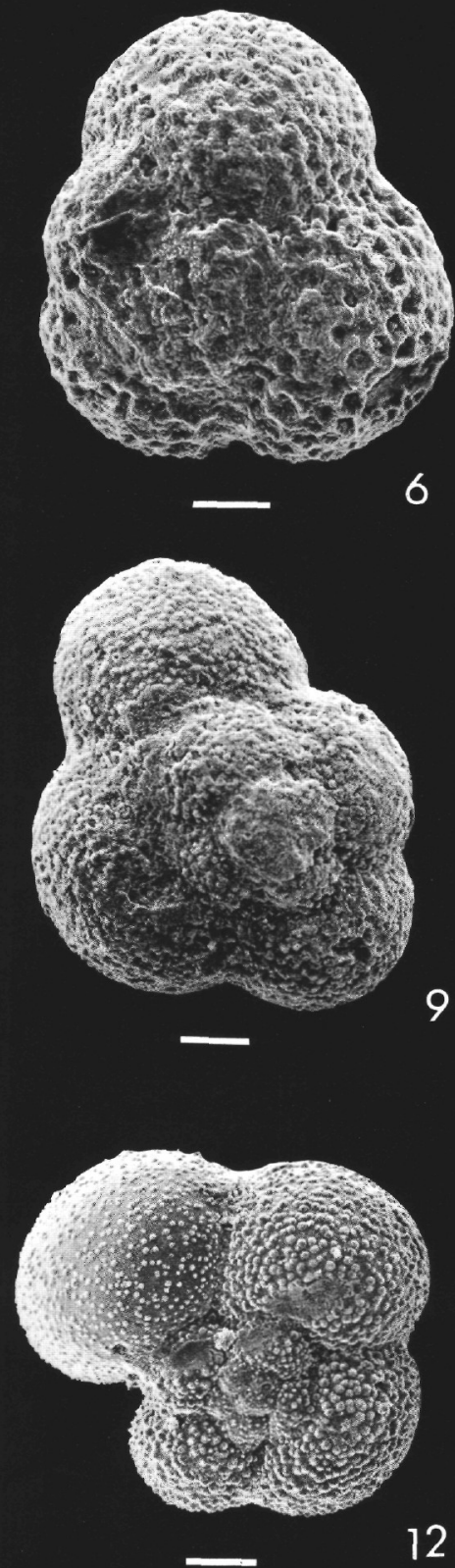
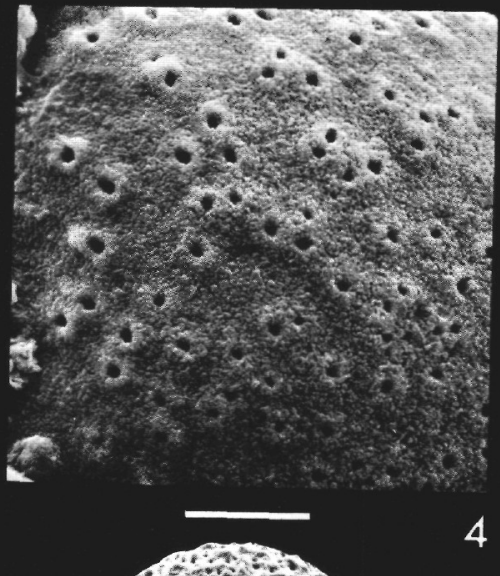

4
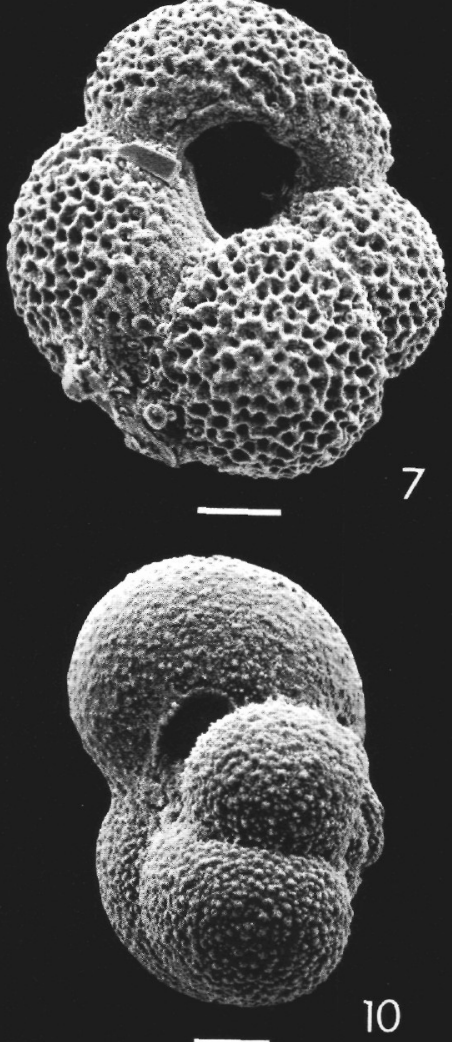

10

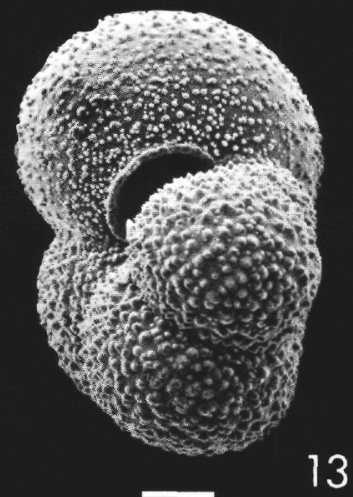

